\title{
Élelmiszeriparban használható illóolajok fertőtlenítő és antimikrobiális hatásának vizsgálata
}

Doktori értekezés

\author{
Vidács Anita
}

\author{
Témavezetők: \\ Dr. Krisch Judit \\ egyetemi docens \\ Prof. Dr. Vágvölgyi Csaba \\ tanszékvezető egyetemi tanár
}

Biológia Doktori Iskola

Szegedi Tudományegyetem

Természettudományi és Informatikai Kar

Mikrobiológiai Tanszék

Szeged

2018 


\section{Tartalomjegyzék}

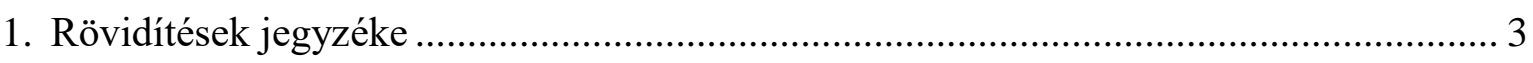

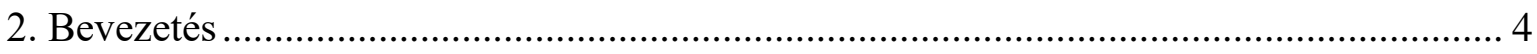

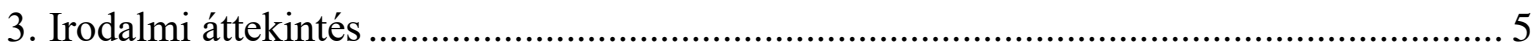

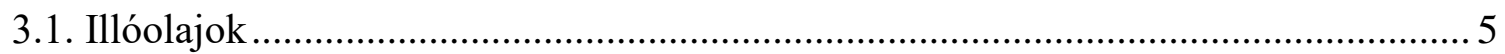

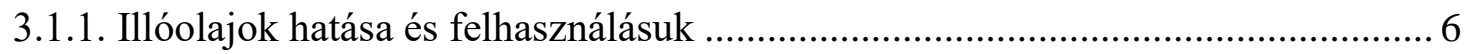

3.1.2. Vizsgált illóolajok bemutatása .................................................................... 9

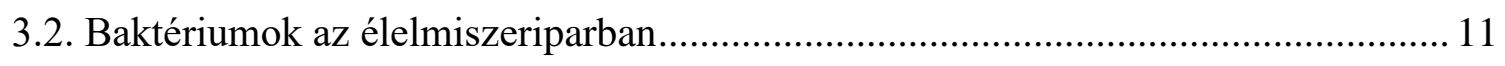

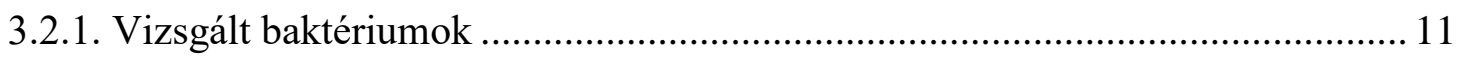

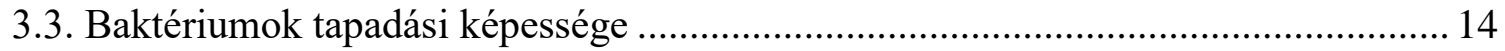

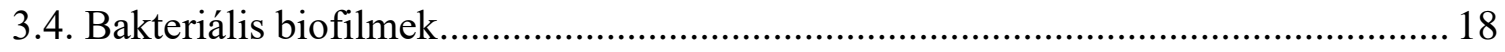

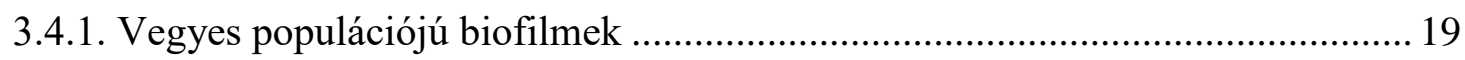

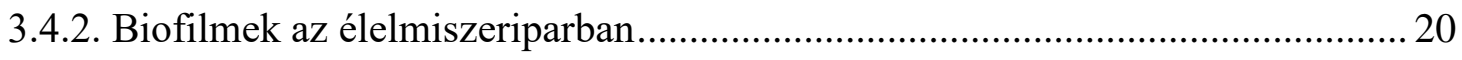

3.4.3. Biofilmek elleni védekezés és megszüntetés .............................................. 21

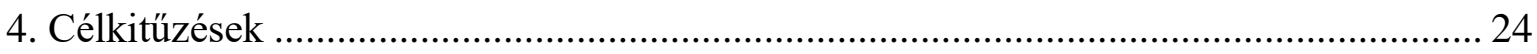

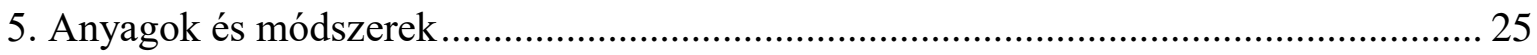

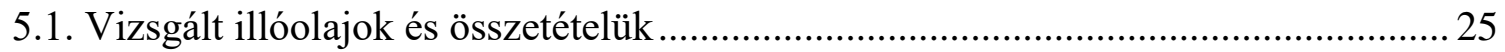

5.2. A vizsgált baktériumok és tenyésztési körülményeik ............................................ 25

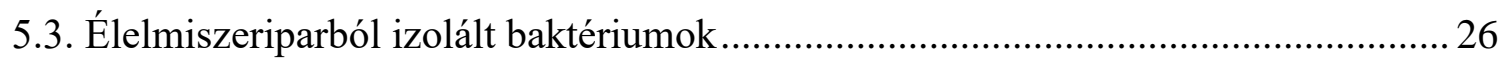

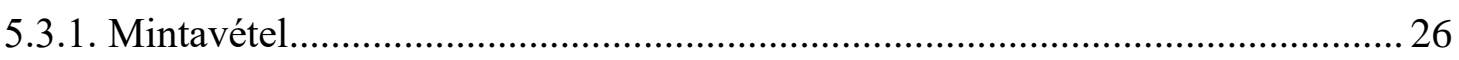

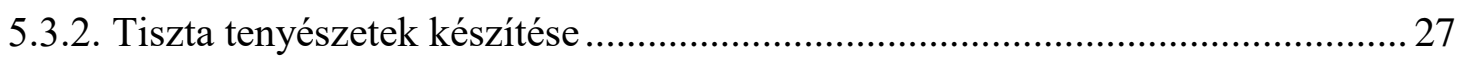

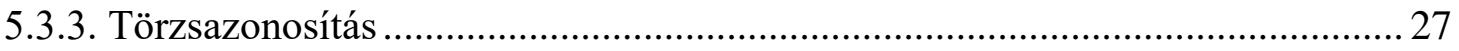

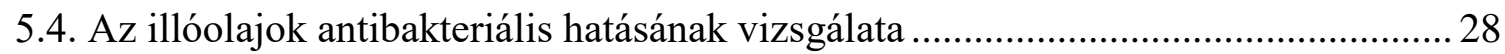

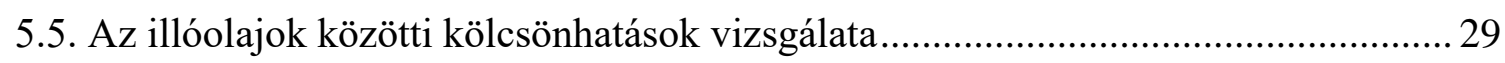

5.6. Baktériumok kitapadási képességének meghatározása különböző felületeken ......... 30

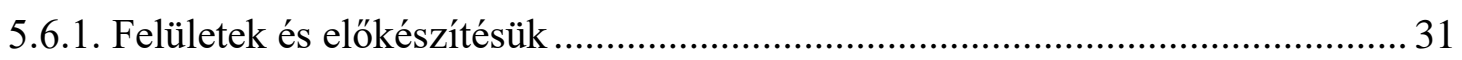

5.6.2. A baktériumok tapadása illóolajos közegben................................................. 31

5.6.3. Tapadás élelmiszermaradványt tartalmazó felülethez.................................... 32

5.6.4. Illóolajjal bevont felülethez való tapadási képesség vizsgálata ......................... 33

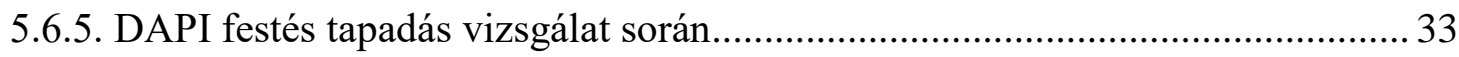

5.7. Illóolajok baktericid kinetikájának meghatározása a koncentráció és pH alapján ... 33 


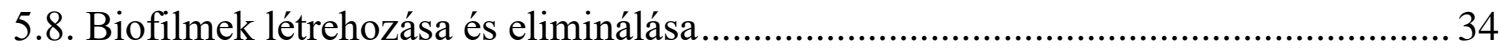

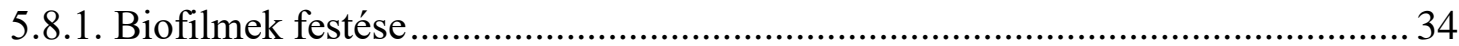

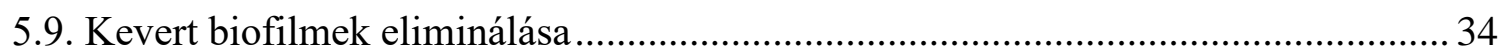

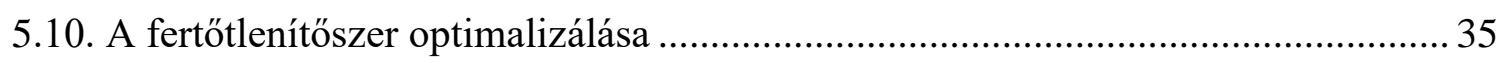

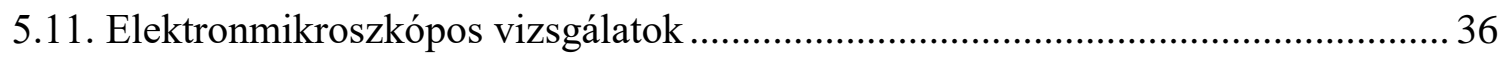

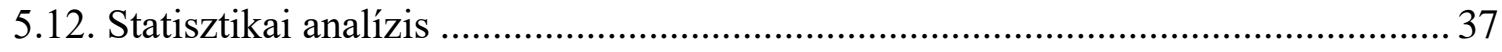

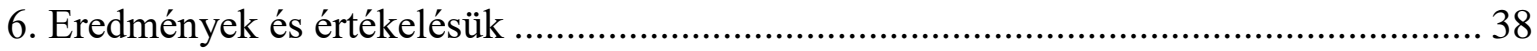

6.1. Az élelmiszeripari üzemekben izolált baktériumok azonosítása ............................ 38

6.2. Az alkalmazott illóolajok MIC és MBC értékeinek meghatározása......................... 39

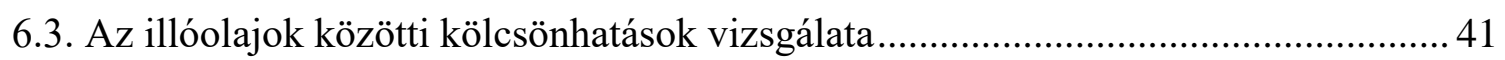

6.4. Tapadás vizsgálat eredményei illóolajos közegben ............................................... 42

6.5. Tapadás vizsgálat eredményei élelmiszermaradványt tartalmazó felületen ............. 46

6.6. Tapadás vizsgálat eredményei illóolajjal bevont felületen .................................... 51

6.7. Illóolajok hatásának kinetikai vizsgálata az idő, koncentráció és $\mathrm{pH}$ alapján ...........52

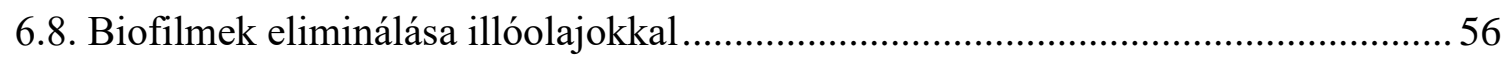

6.9. Az ipari és az illóolajos fertőtlenítőszer összehasonlítása vegyes tenyészeten ........ 64

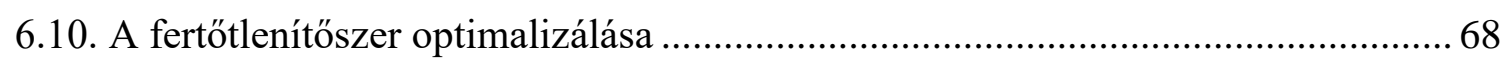

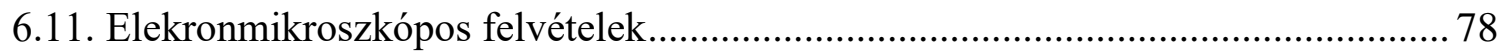

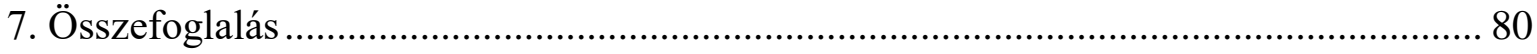

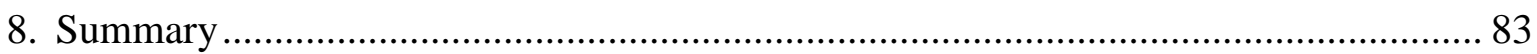

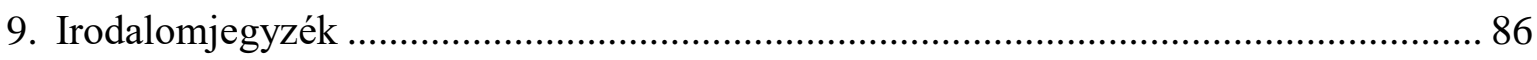

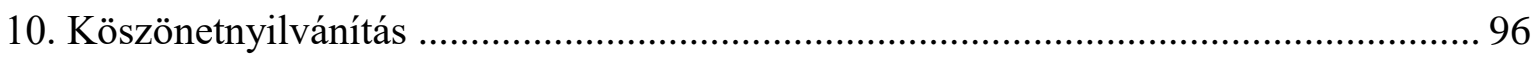




\section{Rövidítések jegyzéke}

BAP: biofilm associated protein - biofilmképzéshez szükséges fehérje

CFU: colony forming unit - telepképző egység

DAPI: 4',6-diamidin-2'-fenilindol-dihidroklorid

DLVO: Derjaguin, Verwey, Landau and Overbeek (elmélet)

EMB: eosin methylene blue - eozin metilénkék agar

EPS: extracellular polymeric substance - extracelluláris polimer anyag

FDA: Food and Drug Administration - Az USA élelmiszerbiztonsági hivatala

FIC: fractional inhibitory concentration - frakcionált gátló koncentráció

FICI: fractional inhibitory concentration index - frakcionált gátló koncentrációs index

GRAS: Generally Recognized as Safe - általánosan biztonságosnak elfogadott

LB: Luria-Bertani tápoldat/táptalaj

MBC: minimum bactericidal concentration - minimális baktericid koncentráció

MIC: minimum inhibitory concentration - minimális gátló koncentráció

MRSA: methicillin rezisztens Staphylococcus aureus

MSSA: methicillin érzékeny Staphylococcus aureus

NCBI BLAST: National Center for Biotechnology Information - Basic Local Alignment

Search Tool

OD: optical density - optikai denzitás

PALCAM agar: polimixin-B-szulfát, akriflavin, lítium-klorid, ceftazidim, eszkulin, mannitol tartalmú agar

PCR: polymerase chain reaction - polimeráz láncreakció

PP: polipropilén

RTE: ready to eat - fogyasztásra kész élelmiszer

SS: stainless steel - rozsdamentes acél

SZMC: Szeged Microbiology Collection - Szegedi Mikrobiológiai Törzsgyüjtemény

TAE: Trisz-acetát-EDTA

TGE: élesztőkivonat-tripton-glükóz tápoldat/táptalaj

TSB: tryptic-soy-broth - tripton szója tápoldat 


\section{Bevezetés}

A baktériumok képesek az élelmiszeriparban és az egészségügyben található különböző felületeken megtapadni és ott biofilmet létrehozni. Ebben a komplex rendszerben a baktériumok ellenállóbbak a káros környezeti hatásokkal szemben (pl. hő, UV sugárzás, fertőtlenítőszerek és antibiotikumok). A kitapadást több környezeti tényező is segíti, ilyen a felület hidrofobicitása és érdessége, illetve a felületen lévő élelmiszermaradvány, amely táplálékforrást jelent a baktériumok számára. A biofilmben élő baktériumok képesek szennyezni a termékeket és betegségeket okozni. A biofilmek elleni védekezés első feladata a tapadás gátlása. Ha a tapadás kialakul, a kolónia eltávolítása nehezebb.

A fertőtlenítőszerekkel történő hosszabb idejü kezelés növelheti a baktériumok ellenállóképességét az adott szerrel szemben, ezért szükséges, hogy újabb, jó antimikrobiális hatással rendelkező anyagokat találjunk. Az utóbbi években egyre nő a természetes tulajdonságaikat megőrző, minimálisan feldolgozott termékek piaca, és ez a trend változásokat hozott az élelmiszeriparban. Egyre több kutatás foglalkozik a természetes eredetű hatóanyagok felhasználásával az élelmiszer eredetű kórokozók elleni védekezésben. Az antimikrobiális, antifungális és antivirális hatással rendelkező illóolajokat különböző füszer- és gyógynövényekből vonják ki, melyek többsége az FDA (Food and Drug Administration) által felállított GRAS (általánosan biztonságosnak elfogadott) kategóriába esik.

Célkitüzésünk volt a vizsgált illóolajok antimikrobiális, tapadásgátló és biofilmeltávolító hatásának vizsgálata élelmiszerszennyező baktériumokon (Escherichia coli, Pseudomonas putida), élelmiszer eredetű kórokozókon (Bacillus cereus, Bacillus subtilis, Listeria monocytogenes, Staphylococcus aureus) és az ezekből alkotott vegyes tenyészeten. A vizsgálatba bevontuk a methicillin-rezisztens Staphylococcus aureus-t, illetve az élelmiszeripari felületekről izolált törzseket (Pseudomonas, Escherichia, Enterobacter, Serratia, Citrobacter sp.) is. A végső cél egy alternatív, „zöld” fertőtlenítőszer kifejlesztése volt. A vizsgált illóolajok a boróka-, a citrom-, a fahéj-, a kakukkfü-, a majoránna- és a muskotályzsálya-olajok voltak. Az illóolajok tapadás- és biofilmképzés-ellenes hatékonyságát élelmiszeripari üzemből származó, de a háztartásokban és az egészségügyben is megtalálható, rozsdamentes acél és polipropilén felületeken vizsgáltuk. A vizsgálat a kevert tenyészet által képzett biofilm esetén kiterjedt fa és csempe felületre is. 


\section{Irodalmi áttekintés}

\subsection{Illóolajok}

Az illóolajok zsíroldékony, illékony, kismolekulájú vegyületek keverékeiből álló folyadékok, melyek az egyes növényi részekböl (szár, levél, gyökér, virág, kéreg) különbözö eljárásokkal (pl. vízgőz-desztilláció, sajtolás, extrahálás, mikrohullámmal való kezelés) vonhatók ki (Burt, 2004; Oussalah és mtsi., 2006). Már az ókorban is használták ezeket az olajokat parfümként. A 13. században a gyógyszerkészítmények előállítása során is használtak illóolajokat. A 16. században élt Paracelsus von Hohenheim kutató teóriája szerint a lepárlás során a legszublimálóbb extraktum a „Quinta essentia”, mely a gyógynövények (drogok) hatékony része, és ezek extrahálása lehetne a gyógyszerészet célja (Burt, 2004; Guenther, 1948). Az elmúlt századokban egyre több növényi kivonatnak vizsgálták az antimikrobiális hatását. Jelenleg körülbelül 3000 illóolaj ismert, ezek közül 300-at alkalmaznak a gyógyászatban, mezőgazdaságban, élelmiszer-, kozmetikai- és illatszeriparban (Bakkali és mtsi., 2008; Hyldgaard és mtsi., 2012).

Az illóolajok általában folyadékok, de egyes olajok szobahőmérsékleten szilárd vagy gyantaszerü halmazállapottal rendelkeznek. Általában könnyebbek a víznél. Színük a halványsárgától, zöldestől a pirosas, barnás színig terjed. Az illóolajok több komponensből állnak. A biológiai hatásért általában a főbb komponensek felelősek, míg az egyes főkomponensek hatását erősíteni, illetve gyengíteni is tudják a minor (kisebb arányban előforduló) vegyületek. Az illóolajok föként terpénekből, terpenoidokból (a terpénhez oxigén molekula kapcsolódik), aromás és alifás vegyületekből állnak. Emellett az olajokban kisebb mennyiségben megtalálhatóak savak, alkoholok, aldehidek, laktonok és kis molekulatömegü nitrogén- és kéntartalmú vegyületek is (Bajpai és Baek, 2016; Bakkali és mtsi., 2008; Nazzaro és mtsi., 2013). A terpén vegyületek izoprén $\left(\mathrm{C}_{5}\right)$ alegységekből állnak, főként monoterpének $\left(\mathrm{C}_{10}\right)$ és szeszkviterpének $\left(\mathrm{C}_{15}\right)$. A terpének nyílt láncú vagy gyürüs szénhidrogének (p-cimén), míg a terpenoidok funkciós csoportjaik alapján lehetnek aldehidek (nerál), alkoholok (linalool), észterek (linalil-acetát), fenolok (timol) vagy ketonok (kámfor). Az aromás gyürüt tartalmazó vegyületek kevésbé gyakran fordulnak elő, ide is tartozhatnak aldehidek (fahéjaldehid) és fenolok (eugenol). Nitrogén- vagy kéntartalmú vegyületek közé tartoznak a glükozinolátok vagy izotiocianát származékok (fokhagyma, mustárolaj) (Bajpai és Baek, 2016; Bakkali és mtsi., 2008; Burt, 2004). Az 1. ábrán néhány gyakori illóolaj összetevő szerkezeti képlete látható. 
<smiles>Cc1ccc(C(C)C)c(O)c1</smiles>

timol<smiles>Cc1ccc(C(C)C)cc1</smiles>

p-cimén<smiles>O=C/C=C/c1ccccc1</smiles>

fahéjaldehid<smiles>C=CCN=C=S</smiles>

alil-izotiocianát

1. ábra. Néhány gyakori illóolaj összetevő.

\subsubsection{Illóolajok hatása és felhasználásuk}

Számos illóolajnak van antibakteriális, antifungális, antivirális és antiparazita hatása. Hidrofób tulajdonságuk révén az illóolajok könnyen átjutnak a sejtfalon és megváltoztatják a sejtmembrán áteresztőképességét. A Gram-negatív és a Gram-pozitív baktériumok különböző sejtfalszerkezettel rendelkeznek, ennek köszönhetően általánosan elmondható, hogy a Gram-negatív baktériumok ellenállóbbak az illóolajokkal szemben. A külső membrán felszínén egy lipopoliszacharid réteg van, mely nehezen átjárható a hidrofób vegyületek számára. A sejtbe került illóolaj komponensek képesek koagulálni a citoplazma fehérjéket, ezáltal megváltozik a sejtmembrán áteresztőképessége, ami a makromolekulák szivárgásához, majd végül a sejt líziséhez vezet. Emellett az intracelluláris ATP szint csökkenése miatt foszfátvesztés következik be. Az illóolajok károsítják a lipideket, kicsapják a fehérjéket és hatással lehetnek a DNS transzkripcióra és a fehérjeszintézisre is (Bakkali és mtsi., 2008; Burt, 2004). Emellett az illóolajok képesek gátolni az elektrontranszport-láncot, a proton által indukált ATP szintézist, és a mitokondriális légzést is (Bajpai és Baek, 2016; Bakkali és mtsi., 2008; Burt, 2004). Az illóolajok megváltoztatják a sejtmembrán zsírsavösszetételét, a „quorum sensing” (baktériumok közötti kommunikáció) aktivitást, a baktériumok megtapadási és biofilmképzési képességét, a sejtek mozgékonyságát (Nazzaro és mtsi., 2013) és felülírhatják egyes rezisztens Gram-negatív baktériumok efflux pumpájának működését (Solórzano-Santos és Miranda-Novales, 2012). Ezeket a hatásokat az illóolaj keverékek és az egyes illóolaj összetevők is képesek kifejteni.

Az illóolajok hatásának vizsgálatára többféle módszer is alkalmas lehet. Szilárd táptalajon alkalmazható a korongdiffúziós, lyukdiffúziós vagy az agar hígításos módszer, míg folyadék tenyészetekben mikro- és makrohígításos teszteket használnak. Minden módszer esetében az illóolajok különböző koncentrációit alkalmazva állapítják meg a 
minimális gátló koncentrációt (minimum inhibitory concentration, MIC), azaz azt a legkisebb illóolaj koncentrációt, ami gátolja a sejtek szaporodását; és a minimális baktericid koncentrációt (minimum bactericidal concentration, MBC), azaz azt a legkisebb illóolaj koncentrációt, ami a sejtek pusztulását eredményezi. A sejten lévő fizikai változásokat mikroszkóppal értékelik (Periccone és mtsi., 2105). A kölcsönhatás tesztek során az illóolajokat, illetve az illóolaj komponenseket különböző mennyiségben keverik össze a sakktábla módszer alapján. Ezekből a tesztekből kiderül, hogy a különböző illóolajok, illetve komponensek egy keverékben hogyan hatnak egymásra: segítik, vagy éppen gátolják egymás müködését (Bassolé és Juliani, 2012).

A különböző illóolajok együttes alkalmazásának azonban vannak korlátai. A legrosszabb esetben antagonista hatás léphet fel, tehát az olajok egymás hatását gyengítik. Fenolos és alkoholos összetevőket tartalmazó olajok egymással való vegyítése esetén a tapasztalat szerint az antimikrobiális hatást növelni tudjuk, így elegendő kisebb mennyiségben felhasználni ezen olajokat (Bassolé és Juliani, 2012). Az olajok mennyiségének csökkentésével a rájuk jellemző erős illat is mérsékelhető, így az élelmiszerekben történő alkalmazás során akár kedvezően is befolyásolhatják a termék érzékszervi megítélését. Fertőtlenítőszerek esetén pedig kellemes kísérő illatot kaphatunk, szemben a ma használatos erősen fertőtlenítő szagú szerekkel szemben.

A terpenoid komponensek közötti hatás függhet a hidroxil csoport jelenlététől, helyzetétől, a kettős kötés helyétől, illetve a fenol gyürün található hidroxil csoportok számától. Azok a komponensek bizonyulnak hatásosabbnak, melyek több hidroxil csoportot tartalmaznak (Gyawali és Ibrahim, 2014). Egyes esetekben az illóolaj hatásosabb, mint a fö komponensek önmagukban (Burt, 2004), ami gazdaságilag is előnyösebb, mivel az illóolaj kivonása olcsóbb, mint az egyes komponensek szintézise (Mourey és Canillac, 2002).

Az illóolajokat gyógyszerkészítményekben is felhasználják. Számos megbetegedés mögött az élelmiszerekben jelenlévő kórokozók állnak, így tartósítószerként is használhatjuk őket az élelmiszeriparban. Tartósítószerként való alkalmazásuk során azonban több probléma is felmerülhet. Egyrészt már kis koncentrációban is negatívan befolyásolhatják az érzékszervi tulajdonságokat jellegzetes, erős illatuk miatt (Hyldgaard és mtsi., 2012), másrészt az illóolajok hatását az élelmiszer tápanyagtartalma is képes negatívan befolyásolni.

Összességében elmondható, hogy minél magasabb az élelmiszerek zsír, fehérje, rost és szénhidráttartalma, annál több illóolajra van szükség a bennük lévő mikroorganizmusok 
növekedésének gátlásához és/vagy elpusztításához. Ezek a tápanyagok ugyanis segítik a mikroorganizmusokat a gyorsabb regenerálódásban stresszhatás esetén, vagy képesek az egyes illóolaj komponensek megkötésére (Burt, 2004; Calo és mtsi., 2015; Gutierrez és mtsi., 2009; Perricone és mtsi., 2015). Egyes fehérjék megkötik a fenolokat az amino- és hidroxilamin csoporton keresztül (Juven és mtsi., 1994). Ezzel szemben, alacsonyabb pHjú, magasabb sótartalmú vagy nagyobb vízmegtartó képességủ élelmiszerek növelik az illóolajok hatását (Negi, 2012; Bajpai és Baek, 2016). Zöldség, gyümölcs és fogyasztásra kész (RTE) élelmiszerek esetén az illóolajok használata célszerü lenne, mivel ezek feldolgozása során a természetes védőréteget eltávolítva megnő a baktériumok elszaporodásnak esélye, ezáltal megnövekedhet a diétázók, vegetáriánusok és különleges táplálkozási igényű emberek körében az élelmiszer eredetű megbetegedések száma. Az élvezeti érték is növelhető egy jól megválasztott illóolaj segítségével, így a tartósítás mellett egyben a termék tulajdonságai is javíthatók (Bajpai és Baek, 2016). Espina és munkatársai (2014) megállapították, hogy az illóolajok egy bizonyos koncentrációig javítják a különböző élelmiszerek érzékszervi tulajdonságait, vagy legalábbis nem változtatják meg. Az illóolajos mosás a káposztalevelek érzékszervi tulajdonságait elfogadható mértékben változtatta meg, de minél hosszabb volt a mosási idő, annál kedvezőtlenebbek lettek az organoleptikus tulajdonságok (Fisher és Phillips, 2006).

Összefoglalva elmondhatjuk, hogy az illóolajok alkalmasak antimikrobiális szerekként történő alkalmazásra. Használatukhoz azonban nélkülözhetetlen annak ismerete, hogy milyenek a környezeti tényezők, és azok hogyan befolyásolják hatásukat. Az élelmiszerekben történő alkalmazásuk több akadályba ütközik a fent említettek alapján, de általános fertőtlenítőszerként jó alternatívák lehetnek az élelmiszeriparban, egészségügyben is. Pozitív tulajdonságuk, hogy általában nem okoznak mutációt a sejtekben, biztonságos élelmiszer összetevők, alacsony a toxicitásuk, környezetbarátok és a fogyasztók jobban kedvelik őket a kémiai szerekkel szemben. A rezisztencia kialakulásának kicsi az esélye, mivel az illóolaj komponensek mennyisége és aránya gyártási tételenként kis mértékben változhat, és ehhez a mikroorganizmusok nem képesek alkalmazkodni. Az összetétel változhat attól függően, hogy hol termesztették a növényt, milyen volt az időjárás, és virágzás előtt vagy után szedték le az adott növényt (Bakkali és mtsi., 2008; Burt, 2004; Tajkarimi és mtsi., 2010). Virágzás után (mag fejlődéskor, érett állapotban) általában magasabb az olaj kihozatal és jobb a minőség is (Kakaraparthi és mtsi., 2014; Usano-Alemany és mtsi., 2016). 
Az illóolajok nemcsak egy biológiai folyamatra hatnak, a mikroorganizmusok ezért is kevésbé képesek ellenállni az illóolajok hatásának (Bakkali és mtsi., 2008; Burt, 2004). Ez különösen előnyös akkor, amikor egy felületen többféle baktérium is található, mivel az illóolajok képesek az összes baktériumra gátló hatást kifejteni (Bakkali és mtsi., 2008). Ebben az esetben a legellenállóbb baktériumra kell meghatározni az MBC értéket, amennyiben hatékony fertőtlenítőszert kívánunk az illóolajokból előállítani.

\subsubsection{Vizsgált illóolajok bemutatása}

Boróka illóolaj

A boróka illóolajat a Juniperus communis álbogyójából vonják ki vízgőzdesztillációval 2-3\% kihozatali mennyiségben. A kinyert olaj színtelen vagy halványsárga, illata füszeres, a fenyőre és borsra emlékeztető. Az olaj fő összetevője az $\alpha$-pinén (40\%), emellett jellemző alkotó vegyülete még a mircén (12\%), a $\beta$-pinén (7\%) és a terpinén-4-ol (6\%). Az olaj élettani hatásai között említendö, hogy vizelethajtó, csökkenti a krónikus ízületi gyulladást, illetve általános gyulladáscsökkentőként tartják számon. Megtalálható egyéb, a légutakra ható készítményekben (pl. légzést segítő kenőcsök, szauna olajok) is. Mozgásszervi megbetegedések kezelésére is használják (Aromax-boróka). A borókaolaj antimikrobiális hatásával kapcsolatban régebben kevés irodalmi adat állt rendelkezésre, manapság egyre több a kutatás ezen a téren (Bakkali és mtsi., 2008; Hyldgaard és mtsi., 2012; Hyun és mtsi., 2015; Mith és mtsi., 2014; Perricone és mtsi., 2015; Tajkarimi és mtsi., 2010).

\section{Citrom illóolaj}

A citromolajat a Citrus limon gyümölcs héjából préseléssel nyerik ki 0,5-1,5\%-ban. Az olaj halványsárgás színủ és erősen citrom illatú. Antimikrobiális és antivirális hatással rendelkezik, ezért légtér fertőtlenítésre is használják. Szélhajtó hatása is ismert. Megtalálható különböző kozmetikai termékekben is, mint például nyugtató fürdőkészítményekben és bőrápolókban. Főbb komponensei a limonén (60-80\%), a $\beta$ pinén és a $\gamma$-terpinén (10\%), valamint a bergaptén $(0,15-0,25 \%)$ (Aromax-citrom). Antimikrobiális hatásáról is vannak adatok, például gátló hatást mutatott Klebsiella spp., Streptococcus és Staphylococcus spp. esetében (Bakkali és mtsi., 2008).

Fahéj illóolaj

A fahéj illóolajat a Cinnamomum zeylanicum kérgéből állítják elő vízgőzdesztillációval, a kihozatal $0,5-4 \%$. Az olaj színe világos, illata füszeres, fahéjas. Fő 
komponense a fahéjaldehid (90-98\%) (Aromax-fahéj). Változatos élettani hatása ismert, pl. tonizáló, bélmozgást serkentő és gyulladásgátló hatás. Kiemelendő antimikrobiális, parazita- és vírusellenes hatása. Már kis mennyiségben is hatásos a különbözö mikroorganizmusok ellen, mivel a sejtmembrán áteresztőképességét megnöveli, így a citoplazma létfontosságú összetevőinek szivárgását okozza (Hyldgaard és mtsi., 2012).

$\underline{\text { Kakukkfü illóolaj }}$

A kakukkfü illóolajat a Thymus vulgaris virágos hajtásából nyerik ki vízgőzdesztillációval 1-3\% hozamban. Színe színtelen vagy halványsárga, illata jellegzetesen füszeres. A gyógyászatban különböző fertőzések kezelésére használják: gyulladáscsökkentő, köhögéscsillapító és antimikrobiális tulajdonsággal is rendelkezik, így a bőr gombás és bakteriális fertőzésére ajánlott termékekben is megtalálható. Az illóolaj legfőbb összetevője a timol (30-50\%) (Aromax-kakukkfü). Hatásmechanizmusa azon alapszik, hogy a sejtmembránt átjárhatóvá teszi. Hyldgaard és munkatársai (2012) megállapították, hogy a külső membránfehérjékben okozott változást Erwinia baktérium esetében. Élelmiszerekben történő használata során az eltarthatósági időt már $0,1 \%$-os koncentrációban is növeli (Bajpai és Baek, 2016). Fontos kihangsúlyozni, hogy képes baktérium biofilmek kialakulását is gátolni (Szczepanski és Lipski, 2014).

Majoránna illóolaj

A majoránnaolajat bimbós vagy virágzás elején lévő Origanum majorana száraz hajtásából nyerik ki vízgőz-desztillációval 0,5-3\%-ban. Az illóolaj színe halványsárga, borostyánsárga, illata erősen füszeres. Antibakteriális, fertőtlenítő, nyugtató, fájdalomcsillapító, emésztésjavító és keringésfokozó hatással is rendelkezik. Az illóolaj főbb komponensei: terpinén-4-ol (10-25\%), terpinén (5-20\%), 1,8-cineol (5-10\%), szabinén (5-10\%), valamint linalool és linalil-acetát (összesen kb. 10\%) (Aromaxmajoránna). Bajpai és Baek (2016) vizsgálatai során az illóolaj 0,3\% alatti koncentrációban több mint egy nagyságrenddel tudta csökkenteni a darált húsban lévő baktériumok számát. Maga a növény kedvelt füszernövény.

Muskotályzsálya illóolaj

A muskotályzsálya-olajat kis mennyiségben (0,2-1\%) vízgőz-desztillációval nyerik ki a Salvia sclarea virágzó hajtásaiból. Az olaj világossárga színü, muskotályos borra emlékeztető füszeres illatú. Fő alkotóelemei a linalil-acetát (50-75\%) és a linalool (1025\%) (Aromax-muskotályzsálya). Antimikrobiális, nyugtató hatású, illetve genitális 
fertőzések és menstruációs zavarok kezelésére is alkalmas. Bakkali és munkatársai (2008) vizsgálatai szerint a muskotályzsálya-olaj kevésbé jó antimikrobiális szer. Kuźma és munkatársai (2009) kutatása szerint a Gram-negatív E. coli négyszer érzékenyebb volt a muskotályzsálya-olajra, mint a Gram-pozitív $S$. aureus.

\subsection{Baktériumok az élelmiszeriparban}

Az élelmiszer eredetủ fertőzések, illetve mérgezések okozói gyakran baktériumok. A baktériumok származhatnak az alapanyagból vagy keresztszennyeződésekből, amennyiben az élelmiszerek előkészítése vagy tárolása során nem tartják be a higiéniai elöírásokat. Külön említést érdemelnek a zoonózisokat (állatról emberre terjedő betegséget) okozó baktériumok (pl. Salmonella Enteritidis, Campylobacter jejuni). Talajból, ivóvízből bekerülő baktériumok is okozhatnak élelmiszerromlást (Pseudomonas spp., Acinetobacter spp.) (Laczay, 2008).

\subsubsection{Vizsgált baktériumok}

A doktori munka során vizsgált baktériumok a Bacillus cereus, a Bacillus subtilis, a Listeria monocytogenes, a methicillin-érzékeny Staphylococcus aureus (MSSA) és methicillin-rezisztens Staphylococcus aureus (MRSA), az Escherichia coli és a Pseudomonas putida fajokba tartozó izolátumok voltak, melyek fontos Gram-negatív és Gram-pozitív reprezentásai az élelmiszeriparban gondot okozó baktérium fajoknak. Változatos hőmérsékleti körülmények között képesek növekedni, némelyik a savas pH-t is jól tolerálja (Deák és mtsi., 2006; Fonseca és mtsi., 2011; Jay és mtsi., 2005; Pandey és mtsi., 2006) (1. táblázat).

1. táblázat. A vizsgált baktériumok minimum és maximum hőmérséklet- és minimum $\mathrm{pH}$ igénye a szaporodáshoz.

\begin{tabular}{lccccc}
\hline & $\begin{array}{c}\text { B. cereus és } \\
\text { B. subtilis }\end{array}$ & E. coli & L. monocytogenes & P. putida & S. aureus \\
\hline $\begin{array}{l}\text { Hömérséklet }\left({ }^{\circ} \mathrm{C}\right) \\
(\text { min-max })\end{array}$ & $10-55$ & $7-46$ & $0-45$ & $0-35$ & $7-48$ \\
Minimum $\mathrm{pH}$ & 4,9 & 4,5 & 4,1 & 3,0 & 4,0 \\
\hline
\end{tabular}

\section{Bacillus cereus és Bacillus subtilis}

Aerob, pálca alakú, endospórát képző baktériumok, melyek a természetben szinte mindenhol megtalálhatók. Gyakran fellelhetők keményítőt tartalmazó nyers élelmiszereken, tejben, zöldségeken, gyümölcsökön, rizses ételekben. Fertőzött élelmiszer 
elfogyasztása után enterális panaszokat okozhatnak (Deák és mtsi., 2006; Lau és mtsi., 2014). Nem megfelelő sütési hőmérséklet esetén kenyérnyúlósodást okoznak (Bíró, 2014).

\section{Escherichia coli}

Az E. coli az Enterobacteriaceae család tagja (Gram-negatív), az állati és emberi bélflóra egyik összetevője, emellett a bőrön és a garat nyálkahártyáján is megtalálható. Élelmiszeriparban indikátor mikroorganizmusnak tekinthető, mivel jelenlétükből fekáliás szennyeződésre lehet következtetni: az emberi székletben körülbelül $10^{9}$ telepképző egység (CFU)/g gyakorisággal van jelen (Deák és mtsi., 2006). A 4/1998 Egészségügyi Minisztériumi (EüM) rendelet értelmében élelmiszerekben termékenként változó értékkel, $<10 \mathrm{CFU} / \mathrm{g}$ (túró, kenyér, pudingpor) és $<10^{4} \mathrm{CFU} / \mathrm{g}$ (füszerek) között, engedélyezett az $E$. coli jelenléte. A normál bélflóra összetevőjeként az E. coli megakadályozza a patogén mikroorganizmusok megtelepedését a bélben, illetve a vitamin ellátáshoz is hozzájárul a $\mathrm{B}$ és $\mathrm{K}$ vitamin szintézisével (Ádám, 2006). Ugyanakkor számos patogén E. coli törzset is ismerünk, amelyek előfordulása (pl. élelmiszerben és vízben) jelentős közegészségügyi kockázatot jelent. Az enterovirulens E. coli izolátumok több altípusba sorolhatók: enteropatogén E. coli (EPEC), amely csecsemőknél nyákos székletet okoz; enteroinvazív E. coli (EIEC), amely véres hasmenést okoz; enterotoxint termelő E. coli (ETEC), amely szintén hasmenést okoz; enterohaemorrhagiát okozó E. coli (EHEC), amely véres székletet, gyerekeknél és időseknél életveszélyes szövődményeket okozhat; enteroaggresszív E. coli (EaggEC), amely vizes hasmenést okoz (Ádám, 2006).

\section{Listeria monocytogenes}

Gram-pozitív, fakultatív anaerob baktérium. A baktérium onnan kapta a nevét, hogy a szervezetben elszaporodva a vérben a monocita fehérvérsejtek száma megemelkedik (Deák és mtsi., 2006). Hidegtürő, és habár lassan, de képes az élelmiszeripari hütött terekben, a háztartási hütőszekrények által kialakított $3-6{ }^{\circ} \mathrm{C}$-os hőmérsékleten is szaporodni. Széles pH-tartományban képes a túlélésre, illetve a szaporodásra $(\mathrm{pH}$ 4,6-9,5). Akár 0,92 vízaktivitású környezetben is képes szaporodni (Carpentier és Cerf, 2011). Magas sókoncentrációt és hőmérsékletet is túlél (de Oliveira és mtsi, 2010). A jelenleg hatályos jogszabály alapján L. monocytogenes 0 CFU/ 25 g mennyiségben lehet az élelmiszerekben (4/1998 EüM). A 2073/2005 Európai Közösségi rendelet maximum $100 \mathrm{CFU} / \mathrm{g}$ mennyiségben engedi a baktérium jelenlétét az élelmiszerekben, abban az esetben, ha bebizonyított, hogy a tárolási feltételek betartása mellett a sejtszám nem haladja meg a $100 \mathrm{CFU} / \mathrm{g}$-t. Kivételt képeznek a L. monocytogenes 
szaporodását elősegítő, a csecsemőknek szánt és a speciális gyógyászati célra szánt RTE élelmiszerek. Ennek megfelelően, különösen az RTE élelmiszerek (pl. csemege hústermékek, sajtok, füstölt halak, tengeri termékek) esetén kell a Listeria mentességre ügyelni (Allen és mtsi., 2016). Esetenként zöldségeken és hústermékeken is megtalálható (Goh és mtsi., 2014). A gyakran kisebb járványok formájában fellépő liszteriózis akár halállal is végződhet (Caillet és mtsi., 2012). Az egészséges embereknél jelentkező kockázaton túl különösen problémás az immungyenge betegek, illetve a kismamák fertőződése; ez utóbbi esetben szinte elkerülhetetlen a magzat súlyos károsodása, amely gyakran vetéléshez vezet (Allen és mtsi., 2016).

\section{Pseudomonas putida}

A Pseudomonas nemzetség tagjai Gram-negatív, aerob, oxidáz-pozitív, pálca alakú, poláris ostorral mozgó baktériumok (Deák és mtsi., 2006). Gyakran ezek a baktériumok felelősek a hütött húsok esetén jelentkező, jól érzékelhető minőségromlásért, melynek tünetei a kellemetlen szag, színváltozás, gáztermelődés és a nyálkás hús (Giaouris és mtsi., 2014; Oussalah és mtsi., 2006). Szinte mindenütt elöfordulnak, például zöldségeken (Gutierrez és mtsi., 2009), növények gyökerein és vizekben is megtalálhatók (Kavanaugh és Ribbeck, 2012). A tejiparban is nagy problémát tudnak okozni, mivel olyan enzimeket termelnek, melyekre a pasztőrözés hőmérséklete nem hat, így a hőkezelt tejben nemkívánatos érzékszervi elváltozásokat okoznak és a fogyaszthatósági időt rövidítik (Simões és mtsi., 2010). A P. putida könnyen tud adaptálódni a környezetéhez, így szélsőségesebb körülményekhez is (Poblete-Castro és mtsi., 2017).

\section{Methicillin-érzékeny és rezisztens Staphylococcus aureus}

Gram-pozitív, szőlőfürt alakban szerveződő 0,6-1 $\mu \mathrm{m}$ átmérőjü, gömbalakú baktériumok. Aerobok, de képesek anaerob körülmények között is túlélni. Nem rendelkeznek sem csillóval, sem tokkal. Az egyik csoportosításuk a koaguláz enzim termelés alapján történik: megkülönböztetünk koaguláz-negatív és -pozitív Staphylococcus törzseket (Deák és mtsi., 2006.). Egyebek mellett megtalálhatók a bőrön, hajon, a felső légutakban, állatok bőrfelületén is. Számos megbetegedés hátterében állhatnak (Giaouris és mtsi., 2015). Számos virulenciafaktorral rendelkeznek, így például számos szénhidrátot, fehérjét, nukleinsavat bontó enzimet termelnek. Emellett a fagocitákat is képesek elpusztítani és sejtoldó hatású toxint is termelhetnek. A hőálló enterotoxint $10^{5} \mathrm{CFU} / \mathrm{g}$ esetén kezdik el termelni, mely ételmérgezést okoz a fogyasztóknál. Sokféle ételben képesek elszaporodni kis vízaktivitás $(0,83)$ mellett is. Előfordulhatnak tojásokban, 
krémekben, húsokban, tejtermékekben, tésztafélékben is. Ezeknél, illetve más élelmiszereknél is fontos, hogy a termékeket $7{ }^{\circ} \mathrm{C}$ alatt tároljuk, ezáltal gátolni tudjuk a szaporodásukat és az enterotoxin termelésüket (Deák és mtsi., 2016). Jogszabályban foglaltak alapján a maximális sejtszám $10-10^{4} \mathrm{CFU} / \mathrm{g}$ között lehet pasztőrözött tej és hőkezelés után fogyasztandó élelmiszerek esetében (4/1998 EüM rendelet). Állattenyésztés szempontjából a tőgygyulladás okozói (Castelani és mtsi., 2015). Egészségügyi szempontból a methicillin-rezisztens $S$. aureus (MRSA) kiemelkedő fontosságú. Esetenként emberek tünetmentesen is hordozhatják, így nagy gondot kell fordítani az egészségügyben a higiéniai szabályok betartására és a fertőtlenítésre (Warnke és mtsi., 2009).

\subsection{Baktériumok tapadási képessége}

A baktériumok megtapadhatnak és biofilmet formálhatnak különbözö felületeken (2. ábra). A baktériumok a biofilmben ellenállóbbak a környezeti hatásokkal szemben, mint szabad sejtekként. A felülethez való tapadás egy összetett folyamat, mely során a sejtek a felület felismerését követően különböző erők hatására először reverzibilisen, majd irreverzibilisen kötődnek a felülethez. Ezután a sejtek osztódni kezdenek, a biofilm elkezd fejlődni, végül elérve a maximális sejtszámot, baktériumok válnak ki és új felülethez tapadva elkezdik az új biofilm kialakítását (Busscher és van der Mei, 2012; Garrett és mtsi., 2008; Gupta és mtsi., 2016; Hori és Matsumoto, 2010; Petrova és Sauer, 2012; Sanchez-Vizuete és mtsi., 2015).

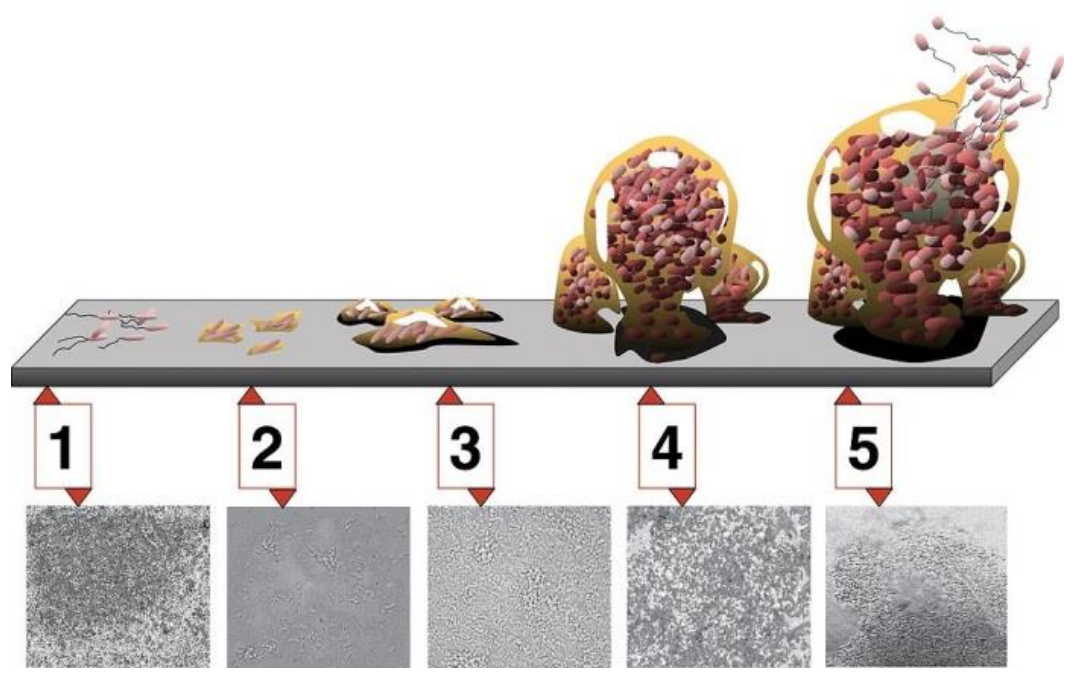

2. ábra. Biofilm képződés folyamata (Monroe, 2007). 1: sejtek megtapadása; 2: mikrokolóniák képzése; 3: fiatal, éretlen biofilm; 4: érett biofilm; 5: sejtek kirajzása. 
A megtapadás és biofilmképzés lassú folyamat, a milliméteres vastagságot több nap/hét alatt éri el optimális környezetben (Kumar és Anand, 1998).

A kezdeti tapadás függ a sejt és a felület fizikokémiai tulajdonságaitól (pl. töltés, hidrofobicitás, felületi érdesség), a hőmérséklettől, a pH-tól, a felületen lévő szennyező- és tápanyagforrásoktól, a baktérium felületi képződményeitől (csilló, ostor) és a felületi fehérjéktöl is, ugyanis $S$. aureus esetén megállapították, hogy az úgynevezett biofilmképzéshez szükséges fehérjék (BAP) jelenléte elengedhetetlen a biofilm kialakításához (Palmer és mtsi., 2007; Casarin és mtsi., 2014; Shi és Zhu, 2009; Srey és mtsi., 2013; Tuson és Weibel, 2013; Van Houdt és Michiels, 2010). A tapadási képesség egy nemzetségen belül is változó, szerovariánsoknál eltérhet, emellett függ attól is, hogy más baktériumok vannak-e a környezetben ( $\mathrm{Li}$ és McLandsborough, 1999). A „curli” tapadási csillóval rendelkező $E$. coli törzsek hamarabb tapadnak meg a felületen, mint az ilyennel nem rendelkezők (Goulter és mtsi., 2009). L. monocytogenes kezdeti tapadását erősítheti, ha a Pseudomonas nemzetségből származó baktériumok is vannak a felületen (Giaouris és mtsi., 2015). Ezzel szemben a B. subtilis norspermidén poliamint termel, mely megakadályozza az E. coli és a S. aureus biofilmképzését; a Bacillus nemzetség egy másik tagja (B. cereus) pedig D-aminosavakat termel, melyek a sejtek szétszóródását, a biofilmképzés gátlását okozhatják a nemzetségen belüli és idegen fajok esetén is (Giaouris és mtsi., 2014). A felülethez való tapadásnál meghatározó erők a Van der Walls, elektrosztatikus, intermolekuláris és a DLVO elméletben szereplő kölcsönhatások (Derjaguin, Landau, Verwey, Overbeek) (Van Houdt és Michiels, 2010; Garrett és mtsi., 2008). A felülethez való kapcsolódáskor még a sejtek tapadása visszafordítható, bármikor le tudnak válni a felületről, a morfológiai változások még nem történtek meg és visszatérhetnek a planktonikus állapotba. A sejtek még képesek ostor által irányított mozgásra vagy csúszásra a felületen.

Az ostor által indukált mozgás fontos az abiotikus felület és a baktérium között kialakuló taszító erő legyőzésében. A külső membránfehérjék és a csillók hozzájárulnak a biztosabb, stabilabb megtapadáshoz (Prakash és mtsi., 2003). A mozgékonyabb sejtek nagyobb számban tapadnak meg és áramlás mellett is képesek a felülethez kötődni. E. coli, L. monocytogenes és $B$. cereus esetén az ostor általi mozgás szükséges a kezdeti megtapadáshoz, míg B. subtilis esetén erre nincs szükség (Abee és mtsi., 2011; Dourou és mtsi., 2011). A tapadási csillók nagy mennyiségü hidrofób aminosavat tartalmaznak és részt vesznek a hidrofób felületeken kialakuló hidrofób-hidrofób kölcsönhatások 
kialakításában (Prakash és mtsi., 2003). L. monocytogenes esetén a hidrofobicitás erősödhet a hőmérséklet emelésével (Di Bonaventura és mtsi., 2008).

Az endospórák hamarabb tapadnak meg a felületen, mert a vegetatív sejteknél nagyobb a hidrofobicitásuk. Nagy felületi érdesség esetén könnyebben tapadnak meg a baktériumok a felületen, mivel kisebb a nyíróerő. A legerősebb tapadás a fa felületen érhető el a porozitás és a megkötő képesség miatt (Shi és Zhu, 2009). A fát használják tradicionális termékek előállítása során, mint például hordóként a bor, ecet és olívaolaj tárolására; dobozként zöldségek, gyümölcsök esetén; füstölökben; sajtformaként és a háztartásokban vágódeszkaként (Aviat és mtsi., 2016). Általánosságban elmondható, hogy hidrofób felülethez (teflon, mủanyag) jobban tapadhatnak a sejtek, mint a hidrofilhez (üveg, fém) (Prakash és mtsi., 2003; Goulter és mtsi., 2009). Ezzel szemben Shi és Zhu (2009) tanulmánya szerint a fémhez hamarabb kötődtek a sejtek, mint a müanyaghoz. Dourou és munkatársai (2011) kísérletük során azt tapasztalták, hogy nem volt különbség a műanyaghoz és a fémhez való tapadás között. Egyöntetü állásfoglalás nincs ezen a téren, így a hidrofobicitás más tényezőkkel együttesen hathat. Az elektropolírozott fémhez kevésbé tudnak tapadni a sejtek, mint a polírozatlan vagy homokkal egyenletesített fémhez (Arnold és Bailey, 2000). A berendezések kialakítása során alkalmazott hegesztések, sarkok, kötések is befolyásolhatják a baktériumok megtapadását.

A felületen lévő élelmiszermaradék is erősítheti a tapadást és a biofilm fejlődést, de a tápanyag mennyisége és milyensége negatívan is befolyásolhatja a tapadást (Shi és Zhu, 2009). Palmer és munkatársai (2007) azt a hipotézist közölték, hogy a kazein és $\beta$ laktoglobulin jelenléte esetén a L. monocytogenes és a Salmonella Thyphimurium kitapadása gyengült rozsdamentes acél felülethez. A szénhidrát anyagcsere is szerepet játszik egyes baktériumok biofilmképzésében, a glükóz ugyanis kis mennyiségben kedvez a Gram-pozitív baktériumok tapadásának és a biofilm fejlődésének (Srey és mtsi., 2013). A környezet hőmérséklete is befolyásolhatja a tapadást, E. coli esetében igazolták, hogy jobban tud a müanyagon kitapadni $30^{\circ} \mathrm{C}$-on, mint $37^{\circ} \mathrm{C}$-on (Shi és Zhu, 2009). Ezzel szemben L. monocytogenes esetén megállapították, hogy minél magasabb volt a hőmérséklet, annál jelentősebb biofilmet képzett (Di Bonaventura és mtsi., 2008). Garrett és munkatársai (2008) azt a felfedezést tették, hogy néhány baktérium $35^{\circ} \mathrm{C}$-on csupán egy ostorral rendelkezett, ezzel szemben $21{ }^{\circ} \mathrm{C}$-on már 2-3 ostort is fejlesztett. $20{ }^{\circ} \mathrm{C}$-on a Pseudomonas fajokból álló tenyészet gomba alakú biofilmet képzett, míg $30-37{ }^{\circ} \mathrm{C}$-on már lapos biofilmet alakítottak ki (Phillips, 2016). A külső környezeti hatások közül a pH is fontos szerepet játszik, kisebb változásához azonban a baktériumok még képesek 
hozzászokni (Garrett és mtsi., 2008). Általában a baktériumok negatív töltésűek pH 5-7 esetén az aminocsoportok karboxil és foszfát vegyületei miatt (Palmer és mtsi., 2007). A kezdeti megtapadási állapotban egy öblítéssel is lemoshatóak a felületről a sejtek (Srey és mtsi., 2013).

A következő tapadási fázisban már újabb erők lépnek fel (kovalens-, és hidrogénkötések, hidrofób kölcsönhatások) a felület és a baktérium között, mely hatására a tapadás már visszafordíthatatlan lesz és a megtapadt sejtek eltávolításához már valamilyen kémiai (takarítószer, enzim) vagy fizikai behatás kell (súrolás) (Palmer és mtsi., 2007; Srey és mtsi., 2013).

$\mathrm{Az}$ irreverzibilis tapadás után a sejtek elkezdenek extracelluláris polimer anyagot (EPS) termelni (Srey és mtsi., 2013). Az EPS-ben lévő poliszacharidok és proteinek meghatározzák a biofilm mechanikus stabilitását. A lipidek és nukleinsavak pedig befolyásolják a biofilm reológiáját és a stabilitását is (Simões és mtsi., 2010). Az EPS védi a sejteket a biofilmben. A biofilmnek több mint 90\%-a EPS (Flemming és Wingender, 2010), ami ioncserélő gyantaként müködik, így képes megkötni a nagy molekulájú antibiotikus molekulákat, és a jelenlévő enzimek lebontják a béta-laktám típusú antibiotikumokat. Prakash és munkatársai (2003) megállapították, hogy a $P$. aeruginosa 32-szer több béta-laktamáz enzimet termel biofilmben, mint szabad sejtként. A különböző antimikrobiális szerek, fertőtlenítőszerek deaktiválása gyorsabban megy végbe a külső rétegekben, mint ahogy azok elérnének a belső rétegekhez (Prakash és mtsi., 2003; Satpathy és mtsi., 2016). A biofilm fejlődése során egyre több sejt kapcsolódik a mátrixhoz és termel EPS-t (Srey és mtsi., 2013), melynek a termelése nő a biofilm korával. Ehhez köthető, hogy az EPS és a liposzacharidok miatt a Gram-pozitív baktériumok a hidrofil felülethez tapadhatnak inkább, míg a tapadási csillókkal rendelkező mikrobák inkább a hidrofób felülethez (Prakash és mtsi., 2003). A fejlődés során kialakul a biofilm alakja (lapos, gomba alakú vagy elterülő), mely a tápanyagforrástól is függ (Srey és mtsi., 2013). A biofilmben már egyes gének kifejeződése is megváltozhat, például a flagellin fehérje (tapadási csillókért felelős) termelése leáll (Shi és Zhu, 2009), külső membránfehérjék mennyisége lecsökken (Goulter és mtsi., 2009) és a fehérjék mennyisége és típusa is megváltozik (Garrett és mtsi., 2008).

A biofilm érése addig folytatódik, amíg el nem éri a kritikus sejtszámot, mely után baktériumok válnak ki a mátrixból és új felületet keresnek, ahol meg tudnak tapadni. A folyamatot indukálhatja enzimatikus bomlás is, az EPS termelés csökkenése vagy a felületkötő fehérjék csökkenése. Az is okozhatja a biofilmből történő kiválást, ha a külső 
környezet nem megfelelő, kevés a tápanyag, ezért a baktériumok éheznek (Srey és mtsi., 2013).

\subsection{Bakteriális biofilmek}

Az első biofilmmel kapcsolatos feljegyzés a 17. század végéről (1684) Leeuwenhoek-tól származik, aki kezdetleges mikroszkóppal vizsgált fogakat, melyek felületén kolóniákba rendeződött baktériumokat talált. Az 1920-as években hajók felületén, majd az 1980-as években már ipari környezetben is azonosítottak biofilmeket (szennyvíztisztítók, ecetgyártó berendezések, élelmiszeripari gépek), majd implantátumokon és katétereken is (Garrett és mtsi., 2008; Shi és Zhu, 2009). A biofilm kifejezésnek több definíciója is létezik, összességében a mikroorganizmusok által különbözö felületeken alkotott halmazt tekintjük biofilmnek, ahol a sejteket egy hidratált EPS anyag veszi körbe (Flemming és Wingender, 2010; Giaouris és mtsi., 2015; Kumar és Anand, 1998; Sanchez-Vizuete és mtsi., 2015; Shi és Zhu, 2009; Srey és mtsi., 2013, Van Houdt és Michiels, 2010).

Az élelmiszer eredetü megbetegedések gyakoriak mind a fejlett, mind a fejlődő országokban. Számos fertőzés kitörésének hátterében a bakteriális biofilmek kialakulását és ezekben a sejtek ellenállóképességét említik (Listeria, Staphylococcus, Campylobacter, Salmonella spp., E. coli) (Simões és mtsi., 2010; Van Houdt és Michiels, 2010). A biofilmben a sejtek akár ezerszer ellenállóbbak lehetnek, mint a szabad sejtek (Phillips, 2016), mert az EPS védi a sejteket a külső káros tényezőktől (pl. UV fény, fertőtlenítőszerek, antibiotikumok, sugárzás, kiszáradás) (Flemming és Wingender, 2010; Prakash és mtsi., 2003; Van Houdt és Michiels, 2010). A rezisztencia hátterében több mechanizmus állhat: mutációk kialakulása, efflux pumpa müködése, célhely megváltoztatása vagy a célmolekula túltermelése, enzimek termelése, melyek lebontják az adott szert (Davidson és Harrison, 2002; Phillips, 2016). Az egyes szereknek az EPS védőrétegen keresztül kell átjutnia és előfordul, hogy hamarabb aktivitásukat veszítik, mint ahogy a célhelyre érnének (Prakash és mtsi., 2003; Satpathy és mtsi., 2016). A biofilm alsó rétegeiben a körülmények megváltoznak, ezáltal mikroaerofil közeg alakulhat ki. A savtermelés következtében a pH változik és egyes antibiotikumok (pl. aminoglikozidok) ilyen körülmények között hatástalanok lehetnek, ami szintén a rezisztencia kialakulását eredményezi (Satpathy és mtsi., 2016; Gupta és mtsi., 2016). 


\subsubsection{Vegyes populációjú biofilmek}

A legtöbb esetben egy biofilmben több baktérium faj található, ezek aránya függ attól, hogy hol helyezkednek el a biofilmben, illetve az egymás között kialakuló kölcsönhatásoktól is. Egyes baktériumok képesek hasznos anyagokat termelni más baktériumok számára, melyek segítik őket a megtapadásban és az együttélésben, míg más esetekben képesek egymással harcolni a tápanyagért, oxigénért vagy pedig olyan enzimeket termelnek, melyek a másikra biocidként hatnak (Elias és Banin, 2012; Giaouris és mtsi., 2015). Ezek a vegyes populációjú biofilmek laposabbak, de stabilabbak, ellenállóbbak, mint a monofajú képződmények (Gomes és mtsi., 2016; Kumar és Anand, 1998; Lebert és mtsi., 2007; Sanchez-Vizuete és mtsi., 2015). Heterogén összetételü kolóniák is megtalálhatóak különféle felületen (fa, müanyag, fém, gumi, üveg) (Aviat és mtsi., 2016; Kumar és Anand, 1998; Prakash és mtsi., 2003; Simões és mtsi., 2010). Különböző oxigénigényü baktériumok (pl. anaerobok és aerobok) szintén képesek együttélni, az anaerobok többnyire a biofilm belsejében találhatóak (Stewart és Franklin, 2008).

Fernandes és munkatársai (2015) Enterococcus faecalis-t vagy E. faecium-ot és $L$. monocytogenes kevertek össze, és azt tapasztalták, hogy a két baktérium tudott egymás mellett szaporodni. Egy tanulmány szerint a $P$. putida az EPS termelés közben megváltoztatja a felület tulajdonságait, mely kedvezően hat a L. monocytogenes biofilm képzésére is. Ennek a hasznos együttélésnek köszönhetően a $P$. putida is kedvező feltételek közé kerül, mivel nő a benzalkónium-kloriddal szembeni toleranciája (Giaouris és mtsi., 2015). Egy másik kísérletben, ahol B. cereus és $P$. fluorescens közös biofilmet alakított ki, a baktériumok kölcsönösen növelték egymás ellenállását klór-dioxidra és glutáraldehid fertőtlenítőszerre (Sanchez-Vizuete és mtsi., 2015). Egy négyes populációjú biofilmben $(P$. fragi, E. coli, S. aureus, L. monocytogenes) egy nap után a baktériumok erőteljesen szaporodtak, kivéve a $S$. aureus-t, ahol a sejtszám stagnált (Lebert és mtsi., 2007). Hasonló eredményre jutottak Rendueles és Ghigo (2012), ahol az E. coli és a $S$. aureus versengése következtében olyan anyag termelödött, mely hatására a $S$. aureus a biofilmben nem tudott szaporodni. Giaouris és munkatársai (2015) szeirnt a $S$. aureus és a L. monocytogenes, illetve a $S$. aureus és a $P$. aeruginosa semleges hatást gyakoroltak egymásra a biofilmben, ugyanakkor Sanchez-Vizuete és munkatársai (2015) szerint a S. aureus virulenciája növekedett $P$. aeruginosa jelenlétében és a $B$. subtilis is kevésbé volt érzékeny a perecetsavra a $S$. aureus-szal alkotott biofilmben (Røder és mtsi., 2016). Salmonella, 
Lactobacillus, Pseudomonas, Listeria nemzetségekhez tartozó baktériumok egymással történő keverése során a Salmonella sejtek száma alacsonyabb volt a biofilmben az egyfajú Salmonella spp. biofilmben tapasztaltakhoz képest (Chorianopoulos és mtsi., 2008).

\subsubsection{Biofilmek az élelmiszeriparban}

A biofilmek az élelmiszeriparban higiéniai és technológiai problémákat is okozhatnak (Kumar és Anand, 1998). Higiéniai probléma esetén a termék mikroorganizmusokkal szennyeződik; ha ennek mértéke eléri vagy meghaladja a jogszabályban előírtakat, akkor egészségügyi kockázatot jelent a termék elfogyasztása. Egyes baktériumok a melléktermékeikkel a termék érzékszervi tulajdonságaira kedvezőtlenül hathatnak (szín, íz, állomány) (4/1998 EüM; 2073/2005 EK; WHO, 2006). Jelenleg az élelmiszer eredetü betegségek elkerülésére még nincs lehetőség, mivel az egész világot átíveli az élelmiszerlánc (egyre messzebb történik a szállítás) és nincs olyan hatékony megoldás, mely a veszélyes mikrobákat megöli, de az élelmiszerekben nem okozna kedvezőtlen elváltozásokat (WHO, 2015).

A zöldségek és gyümölcsök feldolgozása esetén a termékeket mossák, majd csomagolják. A mosóvízbe lévő fertőtlenítőszer elpusztítja a felületen lévő mikrobákat, hogy azok a későbbi munkafolyamatoknál ne jelentsenek kockázatot. Ugyanakkor a szennyezett csomagolóanyagok is keresztszennyezhetik a mikrobiológiailag megfelelő minőségű termékeket, ez állt a 2011-es L. monocytogenes járvány hátterében is (Srey és mtsi., 2013). A friss zöldségek a nagy vízaktivitásuk és tápanyagtartalmuk miatt is segíthetik a mikrobák megtapadását, mivel a feldolgozásuk során elveszíthetik a természetes védörétegüket (Gutierrez és mtsi., 2009). Egyes zöldségek szöveteiben 12 mikrométer mélyen is izoláltak baktériumokat. Kimutatták, hogy a biofilmek ellen sem a klór vagy szerves savakkal történő zöldségmosás, sem az ózonkezelés nem hatott megfelelően. Gutierrez és munkatársai (2009) kísérletében például az E. coli sejtek képesek voltak retekcsírán túlélni 20000 ppm klórtartalmú vizes mosást is. A minimálisan feldolgozott zöldségek esetén az Enterobacteriaceae család képviselői mellett jellemző a Pseudomonadaceae családba tartozó baktérium fajok jelenléte is (Gutierrez és mtsi., 2009). Nagyon jelentős a fogyasztásra kész élelmiszerek szennyeződése is. Már többször izoláltak L. monocytogenes-t hütést igénylő RTE élelmiszerekről (Srey és mtsi., 2013).

Tejipari termékek esetében az Enterobacter, Listeria, Streptococcus, Micrococcus, Pseudomonas és Bacillus nemzetségek jelenthetnek veszélyt. A tejtermék csomagoló berendezésben, illetve a pasztőröző gép utáni csövekben is mutattak ki biofilmeket 
(Simões és mtsi., 2010; Srey és mtsi., 2013), melynek hátterében az állhat, hogy a lassan növekvő populáció képes alkalmazkodni a tejiparban használatos zárt rendszerü fertőtlenítési módszerhez.

Hal- és hústermékek esetén is kockázatot jelentenek a baktériumok (Bajpai és Baek, 2016; Srey és mtsi., 2013), de e termékek a háztartásokban általában hőkezelésen esnek át. Ha az üzemre specifikus Jó Higiéniai Gyakorlat előírásait betartják a gyártás során, a termékek az előírásoknak megfelelőek és a hütőlánc megfelelően biztosított, akkor az esetleges élelmiszer eredetü megbetegedések a helytelen konyhai technológia miatt következhetnek be (Kusumaningrum és mtsi., 2003; Srey és mtsi., 2013). Ezen termékek esetén a következő baktériumok fordulnak elő leggyakrabban: E. coli, Listeria, Salmonella, Pseudomonas, Aeromonas és Campylobacter spp. (Srey és mtsi., 2013). A konyhában a keresztszennyezést okozhatják a konyharuhák, szivacsok és a nem megfelelően tisztított eszközök (Kusumaningrum és mtsi., 2003). A vendéglátói előírásoknak megfelelően külön eszközöket kell alkalmazni a hús és a zöldség, illetve a nyers és a kész ételek kezeléséhez (Útmutató A Vendéglátás és Étkeztetés Jó Higiéniai Gyakorlatához, 2012; WHO, 2006). Otthoni háztartások esetén az az ajánlás, hogy ha nem megoldható a külön eszközök használata, akkor az eszközöket a nyers és a kész ételek (pl. kezeletlen csirkemell és saláta) között fertőtlenítsük, így csökkenteni tudjuk a különböző bakteriális eredetü megbetegedések kockázatát (Goh és mtsi., 2014).

A biofilmek a higiéniai problémák mellett gyakran technológiai problémákat is okoznak, például a biofilmek képesek a membránok eltömítésével a szürés hatékonyságát csökkenteni. A csőrendszerekben az áramlást is csökkenthetik, így a hőcserélö berendezések hatásfoka is csökkenhet. A biofilmekben szulfát felhasználás és savtermelés történik, ami elősegítheti a fém felületek korrózióját is (Kumar és Anand, 1998; Satpathy és mtsi., 2016; Simões és mtsi., 2010).

\subsubsection{Biofilmek elleni védekezés és megszüntetés}

A biofilmek elleni védekezés során az első és legfontosabb, hogy megakadályozzuk a kialakulásukat. Ennek érdekében a Jó Higiéniai Gyakorlat előírásait be kell tartani, tartatni és megfelelő alapanyagokat és berendezéseket kell használni.

A kialakult biofilmek ellen kémiai szerekkel és fizikai behatásokkal lehet védekezni, illetve azokat megszüntetni. A biofilmek ellen a kémiai szerek közül a nátriumhipoklorit a leghatékonyabb, amely alacsony pH-n alkalmazva fejti ki hatását leginkább. Hat százalék nátrium-hipoklorit oldat képes volt az E. feacalis biofilm eltüntetésére. 
Tizenöt perces hatóidővel az 5\%-os hidrogén-peroxid is megszüntette a biofilmet, de a perecetsav alapú fertőtlenítőszert 15\%-os mennyiségben kellett alkalmazni (Srey és mtsi., 2013). Ezzel ellentétben a hidrogén-peroxid alapú fertőtlenítőszer hatástalan volt $L$. monocytogenes biofilm ellen, és kimutatták, hogy a baktérium rezisztens a kvaterner ammónium alapú fertőtlenítőszerre is. A közönséges lúg alapú Easyclean fertőtlenítőszer és a sav alapú Ambersan takarítószer csak egy nagyságrenddel csökkententette a $S$. aureus és a P. aeruginosa biofilmek sejtszámát (Shi és Zhu, 2009). A Listeria, a Pseudomonas és a Staphylococcus fajok kevésbé érzékenyek a benzalkónium-kloridra, míg a $B$. subtilis a glutáraldehidre (Gomes és mtsi., 2016). A biofilmek megszüntetéséhez sok tényezőt kell figyelembe venni, például a felület fajtáját, hatóidőt, a hőmérsékletet, és hogy milyen mikroorganizmusok lehetnek az adott felületen. Aktív klór esetén százszor nagyobb koncentrációt kell alkalmazni biofilmek (Pseudomonas, Staphylococcus, Listeria spp.) ellen, mint szabad sejtek esetén (Van Houdt és Michiels, 2010). A biocidek kevésbé hatásosak vegyes populációjú biofilmek ellen, mint egyfajú baktérium mátrix esetében (Otter és mtsi., 2015).

A fogyasztók körében egyre kedveltebbek a környezetkímélő, úgynevezett zöld megoldások, mint például az enzimek (amiláz, nizin, proteáz, tripszin) és növényi kivonatok (hagymakivonat, illóolajok, növényi szárítmányok) használata a fertőtlenítőszerekben. A biológiai megoldások közé tartozik a fágok használata, amelyek hátránya, hogy egy célfajon hatnak csak, így nem alkalmasak a vegyes tenyészetü biofilmek elleni védekezésre (Phillips, 2016; Satpathy és mtsi., 2016; Srey és mtsi., 2013). A kémiai szerekkel szembeni rezisztencia növekedése miatt egyre többször alkalmaznak illóolajokat a baktériumok elleni védekezésben (Gomes és mtsi., 2016). Rhoades és munkatársai (2013) kísérletükben 3 különböző felülettakarítási módot hasonlítottak össze (vizes rongy, közönséges szappan, oregánó illóolajat tartalmazó szappan), melyek közül a hozzáadott illóolajat tartalmazó szappannal sikerült a legtöbb baktériumot eltávolítani a felületről. Egy másik kutatásban 240 órás Salmonella enterica biofilmet tartalmazó fémlapokat fertőtlenítettek borsmenta és citromfü illóolajos oldattal, és már 20 perc után sikerült a felületröl eltávolítani a baktérium telepeket (Valeriano és mtsi., 2012). A citronella (Cymbopogon nardus) illóolaj 60 perces kezelés után a L. monocytogenes biofilm 94\%-át elpusztította (de Oliveira és mtsi., 2010). Egy másik kísérletben a fahéj, kakukkfü és oregánó illóolajok már 0,031\%-os koncentrációban képesek voltak megakadályozni a bakteriális biofilmek kialakulását (Szczepanski és Lipski, 2014). Vegyes populációjú (Listeria sp., Pseudomonas sp., Staphylococcus sp., E. coli) biofilm ellen már 
a 2\%-os Satureja tymbra (borsikafü) oldat is hatásosnak bizonyult, de teljesen nem tudta elpusztítani a sejteket a biofilmben (Lebert és mtsi., 2007). Desai és munkatársai (2012) 24 órás L. monocytogenes biofilmen történő hatás alapján a következő rangsort állították fel: a leghatékonyabb a kakukkfü és az oregánó illóolaj volt (0,5\%-os mennyiségben), ezután következett a babér és a fahéj, majd a különböző citrusfélék (citrom, narancs), amelyek közül a tangerin volt a legkevésbé hatásos. Az illóolajok amellett, hogy környezetbarát védekezést biztosítanak, olyan szempontból is előnyösek, hogy kevésbé valószínü a rezisztencia kifejlödése, mivel több, különböző hatáspontú komponensböl állnak. Emellett széles hatásspektrummal rendelkeznek (Sieniawska és mtsi., 2013).

A biofilmek elleni fizikai védekezési módszerek közé tartozik a szupermágneses tér, ultrahang technológia és a pulzáló elektromos térerő alkalmazása. E technológiák hátránya, hogy alkalmazásuk nem minden esetben kivitelezhető (élelmiszeripari nagy berendezések, szállítószalag) (Kumar és Anand, 1998). A leghatásosabb és legkíméletesebb eljárás a Hurdle-technológia, mely során több mikrobagátló/pusztító eljárást alkalmaznak együtt, ami lehetővé teszi, hogy a kölcsönhatások miatt az egyes eljárások mértékét csökkentsük (Satpathy és mtsi., 2016; Srey és mtsi., 2013). Erre példa Simões és munkatársai (2010) kísérlete, amelyben rozsdamentes acél felületen lévő $E$. coli biofilmet enzim és ultrahang együttes alkalmazásával 10 másodperc alatt 61-93\%-os hatékonysággal távolítottak el. Egyre jobban elterjed az antibiotikus felületek alkalmazása is, mely során a felületet egy antimikrobiális szerrel vonják be (ezüst, kálcium-karbonát, nano-plazma tirmetil-szilán, szilán xerogél) vagy pedig változtatják a felület bizonyos tulajdonságait (érdesség, töltés, hidrofobicitás). Minél egyenletesebb ugyanis egy felület és minél hidrofilebb, annál kevésbé tapadnak meg rajta a sejtek (Arnold és Bailey, 2000; Satpathy és mtsi., 2016; Srey és mtsi., 2013).

A biofilmek kialakulásának azonban pozitív hatása is lehet. Jelentős szerepük van a biodegradációban a toxikus, illetve káros anyagok lebontása révén. Szennyvíztisztításban a biológiai fázisban alkalmazott baktériumok egy része szintén biofilm formában van jelen, illetve megemlíthető, hogy az élelmiszeriparban használnak olyan fermentációkat, ahol a mikroorganizmusok ellenőrzött körülmények között biofilm formában müködnek (Kumar és Anand, 1998). 


\section{Célkitüzések}

Az élelmiszeriparban egyre nagyobb gondot okoz a különböző hatóanyagokkal szemben kialakuló bakteriális rezisztencia. A baktériumok érzékenységének csökkenése révén az élelmiszer eredetű megbetegedések kockázata is növekszik. Emiatt előtérbe került az olyan új, lehetőség szerint természetes eredetü antimikrobiális anyagok keresése és vizsgálata, amelyek az élelmiszeriparban is felhasználhatók. Ilyen természetes hatóanyagok lehetnek az illóolajok, melyek közül néhányat már tartósítószerként alkalmaznak az élelmiszeriparban, illetve a népi gyógyászatban is alkalmazzák őket különböző megbetegedések kezelésére.

Kutatásunk fő célkitüzése egy természetes hatóanyagot (illóolajat) tartalmazó fertőtlenítőszer kifejlesztése volt, amely hatékonyan képes gátolni a bakteriális biofilmek kialakulását szilárd felületen.

Kutatási célkitüzéseink a következők voltak:

1. A kiválasztott illóolajok (boróka-, citrom-, fahéj-, kakukkfü-, majoránna- és muskotályzsálya-illóolaj) antimikrobiális hatásának vizsgálata.

2. Illóolaj keverékek antibakteriális hatásának vizsgálata és jellemzése.

3. Illóolajok tapadásgátló hatásának vizsgálata élelmiszeriparból származó felületeken, beleértve a technológiai folyamatokra jellemző variációkat (tiszta és élelmiszermaradványt tartalmazó felületek).

4. Az illóolajok baktericid kinetikájának meghatározása.

5. Illóolajos fertőtlenítőoldat különböző érettségü biofilmekre gyakorolt hatásának vizsgálata.

6. Vegyes populációjú biofilmképzés csempe, fém, mủanyag és fa felületen, a biofilmképzés gátlásának vizsgálata.

7. Természetes alapú fertőtlenítőszer optimalizálása és hatékonyságának ellenőrzése. 


\section{Anyagok és módszerek}

\subsection{Vizsgált illóolajok és összetételük}

A kísérletek során felhasznált illóolajokat és azok fő komponenseinek arányát a 2. táblázat foglalja össze. Az adatok az Aromax Kft.-től származnak.

2. táblázat. Illóolajok fö összetevőinek százalékos aránya.

\begin{tabular}{|c|c|c|c|c|c|c|}
\hline \multirow{2}{*}{ Fő összetevő } & \multicolumn{6}{|c|}{ Illóolaj } \\
\hline & Boróka & Citrom & Fahéj & Kakukkfü & Majoránna & Muskotályzsálya \\
\hline$\alpha$-pinén & 40,7 & & & & & \\
\hline ß-pinén & 36,0 & 9,5 & & & & \\
\hline$\gamma$-Terpinén & & 5,6 & & 6,2 & 19,5 & \\
\hline Fahéjaldehid & & & 93,1 & & & \\
\hline Limonén & & 83,2 & & & & \\
\hline Linalil-acetát & & & & & & 84,0 \\
\hline Linalool & & & & 5,1 & & 13,6 \\
\hline p-cimén & 18,9 & & & 31,7 & & \\
\hline Terpinén-4-ol & & & & & 33,6 & \\
\hline Timol & & & & 51,8 & & \\
\hline
\end{tabular}

\subsection{A vizsgált baktériumok és tenyésztési körülményeik}

A kísérletek során felhasznált baktériumokat a 3. táblázatban látható hőmérsékleteken tenyésztettük. A vizsgálatok során vegyes populációjú tenyészettel is dolgoztunk (friss tenyészetek 1:1 arányú keveréke). A baktériumok a Szegedi Mikrobiológiai Törzsgyüjteményből (SZMC) származtak.

3. táblázat. A vizsgált baktériumok azonosítója és tenyésztési körülményei.

\begin{tabular}{lcccc}
\hline Mikroorganizmusok & $\begin{array}{c}\text { Törzsgyüjteményi } \\
\text { azonosító }\end{array}$ & $\begin{array}{c}\text { Gram szerinti } \\
\text { besorolás }\end{array}$ & Tápközeg & $\begin{array}{c}\text { Tenyésztési } \\
\text { hömérséklet }\left({ }^{\circ} \mathrm{C}\right)\end{array}$ \\
\hline Bacillus cereus & SZMC 0042 & pozitív & TGE & 30 \\
Bacillus subtilis & SZMC 0209 & pozitív & TGE & 30 \\
Escherichia coli* & SZMC 0582 & negatív & LB & 37 \\
Listeria monocytogenes* & SZMC 21307 & pozitív & TSB & 37 \\
Staphylococcus aureus* & SZMC 110007 & pozitív & LB & 37 \\
Staphylococcus aureus & SZMC 6270 & pozitív & LB & 37 \\
(MRSA) & & & & \\
Pseudomonas putida* & SZMC 291T & negatív & LB & 25 \\
\hline Vegyes tenyészet & - & mindkettó & LB & 30 \\
\hline
\end{tabular}

*Vegyes tenyészet tagjai

TGE: tripton-glükóz-élesztő tápközeg; LB: Luria-Bertani tápközeg; TSB: tripton-szójatápközeg 
A 4. táblázat a kísérletek során felhasznált tápoldatokat tartalmazza. Táptalajok esetén a tápoldatokat 20g/l agar-agarral egészítettük ki.

4. táblázat. A felhasznált tápközegek összetétele.

\begin{tabular}{ll}
\hline Tápoldat & Összetevők \\
\hline LB & $10 \mathrm{~g}$ pepton \\
& $10 \mathrm{~g} \mathrm{NaCl}$ \\
& $5 \mathrm{~g}$ élesztő \\
\hline TGE & $5 \mathrm{~g}$ pepton \\
& $10 \mathrm{~g}$ glükóz \\
& $2,5 \mathrm{~g}$ élesztő \\
\hline TSB/TSA & $17 \mathrm{~g}$ kazein pepton \\
& $3 \mathrm{~g}$ szója pepton \\
& $2,5 \mathrm{~g}$ glükóz \\
& $5 \mathrm{~g} \mathrm{NaCl}$ \\
& $2,5 \mathrm{~g} \mathrm{~K} \mathrm{HPO}_{4}$ \\
\hline
\end{tabular}

Az adatok $1000 \mathrm{ml}$ tápoldatra vonatkoznak.

Az izolátumok vizsgálata során LB tápközeget használtunk, míg a vegyes populációs vizsgálatokhoz az LB tápközeg mellett szelektív táptalajokat is használtunk (5. táblázat).

5. táblázat. A kísérletek során alkalmazott szelektív táptalajok.

\begin{tabular}{lll}
\hline Baktérium & Táptalaj \\
\hline E. coli & EMB agar (eozin metilén kék) (Scharlau) \\
L. monocytogenes & PALCAM agar (polimixin-B-szulfát, akriflavin, lítium-klorid, \\
& $\begin{array}{l}\text { ceftazidim, eszkulin, mannitol) (Merck) } \\
\text { P. putida }\end{array}$ & Cetrimid agar (Merck) \\
S. aureus & Baird-Parker agar (Biolab) \\
\hline
\end{tabular}

\section{3. Élelmiszeriparból izolált baktériumok}

\subsubsection{Mintavétel}

A mintavétel két különböző élelmiszeripari szektorba tartozó üzemben valósult meg: az egyik egy fagyasztott péksüteményeket gyártó üzem, a másik egy hústermékeket előállító tanüzem. A mintavétel steril mintavevő pálcákkal történt a szállítószalagok és a berendezések felületéröl $(10$ x $10 \mathrm{~cm})$. A levett mintákat steril pepton vízbe helyeztük és a lehető legrövidebb időn belül a laboratóriumba szállítottuk hütött körülmények között, majd rögtön feldolgoztuk. 


\subsubsection{Tiszta tenyészetek készítése}

A mintákat szélesztéssel oltottuk le LB táptalajra, majd a baktériumokat $37^{\circ} \mathrm{C}$-on 24 órán keresztül tenyésztettük. A különálló telepekből vett sejteket LB tápoldatba szuszpendáltuk, majd ismét szélesztettük. A morfológiailag különböző telepeket egyesével izoláltuk, majd LB tápoldatba oltva tenyésztettük $37^{\circ} \mathrm{C}$-on $(24$ h) azonosítás céljából.

\subsubsection{Törzsazonosítás}

Az izolátumok azonosításához DNS-t tisztítottunk a baktérium telepekből, majd a tisztított DNS-ből polimeráz láncreakcióhoz oldatot készítettünk, végül a kapott terméket szekvenáló laborba küldtük és azonosítottuk a mikroorganizmust.

\section{DNS tisztítás}

A DNS tisztítás során az előző nap LB tápoldatba leoltott tiszta tenyészetekből 1,5 ml-t sejtszuszpenziót lecentrifugáltunk és DNS-t kivontuk belőle. $0,5 \mathrm{ml}$ LETS puffert $(0,1$ $\mathrm{M} \mathrm{LiCl}, 10 \mathrm{mM}$ EDTA, $10 \mathrm{mM}$ Tris/HCl, pH8, 0,5\% SDS) adtunk a DNS kivonathoz és 1 percig kevertettük. Ezután 0,5 ml fenol:kloroform:izoamil-alkohol (25:24:1) keverékét is hozzá pipettáztuk és kevertettük, ezután 10 percen át centrifugáltuk. A felső fázist átpipettáztuk egy újabb Eppendorf csőbe és hozzáadtunk 0,6 $\mathrm{ml}$ abszolút etanolt, összekevertük és 10 percig centrifugáltuk. A felülúszót leöntöttük, a kiülepedett DNS-t 0,6 ml 70\%-os etanollal mostuk, majd a beszárított DNS-t $50 \mu 1$ steril desztillált vízben felszuszpendáltuk.

\section{$\underline{\text { Polimeráz láncreakció (PCR) }}$}

A 16S rRNS gént kódoló szakaszt PCR technikával felszaporítottuk. A PCR reakciót az alábbi összetétel szerint végeztük el $25 \mu$ l végtérfogatra:

- 2,5 $\mu$ l puffer (10 x DreamTaq puffer, $20 \mathrm{mM} \mathrm{MgCl}_{2}$ tartalmaz, Thermo Scientific)

- 0,625-0,625 $\mu \mathrm{l}$ EuB8F és $534 \mathrm{R}$ primer (10 x hígítás, tömény: $100 \mu \mathrm{M}$, Thermo Scienfic)

- $2,5 \mu \mathrm{d}$ dNTP mix (2 mM, Fermentas)

- $16,2 \mu 1$ bidesztillált víz

- $0,05 \mu 1$ Taq (10x hígítás, DreamTaq DNA polymerase, $500 \mathrm{U}, 5 \mathrm{U} / \mu 1$, Thermo Scientific)

- $2 \mu 1 \mathrm{DNS}$ 
A PCR program az alábbi lépésekböl állt:

$94{ }^{\circ} \mathrm{C} 2$ perc denaturálás

$94^{\circ} \mathrm{C} 30$ másodperc denaturálás

$51{ }^{\circ} \mathrm{C} 45$ másodperc primer kötődés

$68^{\circ} \mathrm{C} 1$ perc lánchosszabítás

$68^{\circ} \mathrm{C} 10$ perc láncelvarrás

30 ciklus

Az amplifikálásnál alkalmazott primerek az EuB8F (5' AGA GTT TGA TCC TGG CTC AG 3') és az 534 R (5’ ATT ACC GCG GCT GCT GG 3') voltak (Thermo Scienfic).

\section{Agaróz gélelektroforézis}

A nukleinsavak elválasztására agaróz gélelektroforézist használtunk. Az amplifikált mintákat 2\%-os TAE (trisz-acetát-EDTA) agaróz gélen választottuk el TEA (40 mM Trisecetsav, pH 7,6; 1 mm Na2EDTA) puffer használata mellett $120 \mathrm{~V}$-on (40-50 perc), majd etídium-bromidos ( $10 \mathrm{mg} / \mathrm{ml}$ törzsoldat desztillált vízben oldva) festés után UV fény alatt detektáltuk a nukleinsavakat. Az amplifikált fragmentumokat 100 - 1000 bp nagyságú molekulasúly markerhez viszonyítottuk.

$\underline{\text { Szekvenálás }}$

A PCR minták szekvenálását a BAYGEN Intézet (Szeged, Hungary) végezte EuB8F és 534 R primerekkel, majd a mintákhoz tartozó szekvenciák alapján azonosítottuk a baktériumokat a FinchTV program és az NCBI BLAST (National Center for Biotechnology Information - Basic Local Alignment Search Tool) internetes adatbázis alapján.

\subsection{Az illóolajok antibakteriális hatásának vizsgálata}

Az illóolajok minimális gátló koncentrációinak (MIC) meghatározása során mikrohígításos módszert használtunk. Összemértünk $100 \quad \mu 1 \quad 18-20$ órás baktérium tenyészetet $\left(10^{5} \mathrm{CFU} / \mathrm{ml}\right)$ és $100 \mu 1$ különböző koncentrációjú illóolajat 96 lyukú mikrotiter lemezekben (Costar, USA). A kiindulási törzskoncentráció $200 \mathrm{mg} / \mathrm{ml}$ volt, az illóolajokat a baktériumnak megfelelő tápoldatban (lásd 3. táblázat) hígítottuk 2\% Tween 40 segítségével. Az illóolajok végkoncentrációi az alábbiak voltak a mikrotiter lemezekben: $100 ; 50 ; 25 ; 12,5 ; 6,3 ; 3,2 ; 1,6 ; 0,8 ; 0,4 ; 0,2 ; 0,1 ; 0,05 \mathrm{mg} / \mathrm{ml}$. Pozitív kontrollként az illóolajmentes, de Tween 40-t tartalmazó, baktériummal inokulált tápoldat, míg negatív kontrollként és egyben vak mintaként az adott illóolajat és Tween 40-t tartalmazó, 
sejtmentes tápoldat szolgált. Ezután a lemezeket a baktériumok számára optimális hőmérsékleten 24 óráig inkubáltuk, majd kétféle módszer segítségével megállapítottuk az illóolajok MIC értékeit.

Fotometriás módszer: Tenyésztés után a szuszpenziók optikai denzitását (OD) 620 nm-en mértük spektrofotométer (SPECTROstar mikroplate leolvasó, BMG Labtech) segítségével. A negatív kontrollok mérésével ki tudtuk küszöbölni az illóolajos tápoldatok zavarosságát, míg a pozitív kontrollokban tapasztalt baktérium növekedést 100\%-nak tekintettük, ehhez viszonyítottuk az illóolajos tápoldatokban mért OD értékeket. Az egyes illóolajok MIC értékeinek azt a koncentrációt tekintettük, ahol 90\% vagy afeletti növekedésgátlást tapasztaltunk.

Rezazurinos festési módszer: Tenyésztés után a lemezeket $20 \mu 1$ 0,2\%-os rezazurin oldattal (Cell Titer-Blue ${ }^{\circledR}$ Reagent, Promega) festettük meg. A baktériumok oxidoredukciós folyamataik során a kék rezazurint rózsaszín rezorufinná bontják el. Ebből következően a MIC értéket annál a legkisebb illóolaj koncentrációnál határoztuk meg, ahol a festék színe még nem változott (Sarker és mtsi., 2007). Ezt a módszert akkor alkalmaztuk, ha az illóolaj hozzáadása után a tápoldat annyira zavarossá vált, hogy zavarta a fotometriás mérés elvégzését, illetve kiértékelését.

Az illóolajok minimális baktericid koncentrációinak (MBC) meghatározásához 10 $\mu \mathrm{l}$ baktérium szuszpenziót szélesztettünk a megfelelő táptalajra (lásd 3.-5. táblázat) a MIC értéket eredményező, illetve az annál nagyobb koncentrációt tartalmazó lyukakból (Jett és mtsi., 1977). Az MBC értéket annál az illóolaj koncentrációnál határoztuk meg, ami teljesen elpusztította a tápoldatban a baktériumokat, azaz abból kioltva nem jelentek meg telepek a táptalajon.

A további kísérletek során azokat az illóolajokat használtuk, melyek MBC értéke nem haladta meg a $25 \mathrm{mg} / \mathrm{ml}$ értéket. Mivel az illóolajok meglehetősen költségesek, ezért gazdasági szempontokat is figyelembe véve az ipari alkalmazás során a lehető legkisebb, de még hatásos koncentrációban célszerü az alkalmazásuk.

\subsection{Az illóolajok közötti kölcsönhatások vizsgálata}

Az illóolajok közötti kölcsönhatások vizsgálatához 3 illóolajat használtunk, melyek részletezését a 6 . táblázat mutatja be. A kísérletek során a három illóolajat minden lehetséges kombinációban összekevertük, tehát összesen 6 keveréket vizsgáltunk. A sakktábla módszerben használt illóolaj koncentrációk a következők voltak: a baktériumokra jellemző minimális gátló koncentráció, és annak 5 lépcsős felező hígítása, 
valamint a MIC kétszerese (az esetleges antagonista hatások észlelése miatt). Az összes lehetséges illóolaj kombinációt összemértük úgy, hogy a mikrotiter lemez egy sorában az állandó koncentrációjú A illóolaj mellé adtuk a B illóolajat változó koncentrációban, míg az oszlopokban a B illóolaj változatlan koncentrációja mellett az A illóolaj koncentrációja változott. A 96 lyukú mikrotiter lemezek minden zsebében 100-100 $\mu 1$ 10 $\mathrm{CFU} / \mathrm{ml}$ töménységű baktérium szuszpenziót (+2\% Tween 40) kevertünk össze 50+50 $\mu 1$ különböző koncentrációjú, a végkoncentrációhoz képest négyszer töményebb fahéj-, kakukkfü-, illetve majoránna illóolajokkal. A lemezeket 24 órán keresztül a baktériumoknak megfelelő hőmérsékleten inkubáltuk, majd rezazurinnal való festés alapján meghatároztuk a frakcionált gátló koncentráció (FIC) értékeket az egyes illóolajokra az alábbi képlet segítségével.

$$
\mathrm{FIC}_{\mathrm{A} \text { vagy } \mathrm{B}}=\mathrm{MIC}_{\mathrm{A} \text { vagy } \mathrm{B} \text { kombinációban }} / \mathrm{MIC}_{\mathrm{A} \text { vagy B egyedül }}
$$

$\mathrm{Az}$ egyes illóolajok esetén kapott FIC értékek összegéből meghatároztuk a frakcionált gátló koncentrációs indexet (FICI), melynek értékéből következtetni lehet az illóolajok közötti kölcsönhatás típusára.

$$
\mathrm{FICI}=\mathrm{FIC}_{\mathrm{A}}+\mathrm{FIC}_{\mathrm{B}}
$$

Az értékelés az alábbiak szerint történt: FICI $<0,5$ szinergizmus; $0,5 \leq$ FICI $\leq 1$ additív hatás; $1<$ FICI $\leq 4$ indifferens hatás; FICI $>4$ antagonizmus (Gutierrez és mtsi., 2009).

6. táblázat. A kölcsönhatási teszthez használt illóolajok és a fö komponensek kémiai tulajdonságai.

\begin{tabular}{lll}
\hline Illóolaj & Fő komponens & Típus \\
\hline Kakukkfü & Timol & Monociklikus monoterpén-fenol \\
Majoránna & Terpinén-4-ol & Monociklikus monoterpén-alkohol \\
Fahéj & Fahéjaldehid & Aldehid \\
\hline
\end{tabular}

\subsection{Baktériumok kitapadási képességének meghatározása különböző felületeken}

Az élelmiszeriparban leggyakrabban használt felületek a rozsdamentes acél (Arnold és Bailey, 2000) és a különböző müanyagok. Munkánk során ezeken a felületeken vizsgáltuk a baktériumok kitapadási képességét kezeletlen és elökezelt, illetve szennyezett felületek esetén. 


\subsubsection{Felületek és előkészítésük}

A tapadási kísérlet során élelmiszeriparból származó mủanyag (polipropilén hablapát, PP) és rozsdamentes acél (mintázó-gép, SS) 2 x $2 \mathrm{~cm}$-es lapokat használtunk. A lapokat első lépésben mosogatószerrel (Cif) zsírtalanítottuk, desztillált vízzel leöblítettük, megszárítottuk, végül pedig $121,5^{\circ} \mathrm{C}$-on 25 percig sterilizáltuk.

\subsubsection{A baktériumok tapadása illóolajos közegben}

A steril felületeket fahéj-, kakukkfü- és majoránna illóolajat szubletális koncentrációban (7. táblázat) tartalmazó 2-3 x $10^{6} \mathrm{CFU} / \mathrm{ml}$ töménységű baktérium szuszpenzióba helyeztük, amelyet az illóolajok elegyedésének elősegítése érdekében $1 \%$ Tween 40 oldattal egészítettünk ki.

7. táblázat. A tapadásgátlás során használt illóolaj koncentrációk ( $\mathrm{mg} / \mathrm{ml})$.

\begin{tabular}{lccc}
\hline Illóolaj & Kakukkfü & Majoránna & Fahéj \\
\hline E. coli & 0,8 & 0,4 & 0,2 \\
P. putida & - & 0,8 & 0,4 \\
B. cereus & 1,6 & 1,6 & 0,2 \\
B. subtilis & 1,6 & 0,8 & 0,2 \\
L. monocytogenes & 0,8 & 1,6 & 0,8 \\
MSSA & 0,8 & 3,2 & 0,4 \\
MRSA & 6,3 & 0,8 & 1,6 \\
\hline Vegyes populáció & 6,3 & 6,3 & 0,8 \\
\hline Citrobacter sp. & 1,6 & 6,3 & 0,8 \\
Serratia sp. & - & 25 & 1,6 \\
Enterobacter sp. & 0,8 & 12,5 & 1,6 \\
Escherichia sp. & 3,2 & 25 & 1,6 \\
Pseudomonas sp. & 1,6 & 25 & 3,2 \\
\hline
\end{tabular}

A kísérletek során kontrollként illóolaj-mentes tápoldatot használtunk. A mintákat négy órán keresztül inkubáltuk, majd óránként eltávolítottunk egy-egy lapkát. A mintavétel során a felületeket steril vízzel leöblítettük, hogy eltávolítsuk a ki nem tapadt sejteket. Ezután a lapkákat fiziológiás sóoldatba raktuk $(9 \mathrm{~g} / \mathrm{l} \mathrm{NaCl})$ és 5 percen keresztül ultrahanggal (SilverCrest Sur 46 B1, Ultrasonic Cleaner, Németország; 50 kHz, 50 W) kezeltük azokat, annak érdekében, hogy a megtapadt sejteket eltávolítsuk a lapkák felületéről. A lemosott sejteket tartalmazó elegyből decimális hígítási sort készítettünk, majd 100-100 $\mu 1-\mathrm{t}$ a baktériumoknak megfelelő táptalajra (lásd 3.-5. táblázat) szélesztettünk és 24 órás tenyésztés után megállapítottuk a kitapadt élő sejtszámot. 


\subsubsection{Tapadás élelmiszermaradványt tartalmazó felülethez}

Az élelmiszerüzemi körülményeket modellezve kétféle élelmiszert vittünk fel a felületre. A kiolvasztott csirkemell lé a fehérje és zsírszennyeződés hatását, míg a paradicsomlés felület a rostok és szénhidrátok hatását modellezte. A paradicsompürét (Sbudget, $500 \mathrm{ml}$ paradicsompüré, forgalmazza: Spar Magyarország) és az egy hetes fagyasztás után kiolvasztott csirkemell (Spar, Magyarország) levét is 10\%-osra hígítottuk. A pasztörözött paradicsompürét a csomag aszeptikus felbontása után steril desztillált vízzel hígítottuk. A felolvasztott csirkemellből elfolyó levet kuktában sterileztük 15 percig, hogy megakadályozzuk a csirkehús felületéről a lébe bekerült baktériumok elszaporodását.

Az élelmiszerek előkészítése után a lapkákat belemártottuk a hígított oldatokba és lamináris boxban hagytuk rászáradni az élelmiszermaradványokat. A felületeket az 5.6.2. fejezetben leírt módon kezeltük, azaz 2-3 x $10^{6} \mathrm{CFU} / \mathrm{ml}$ töménységű sejt szuszpenziót és különböző koncentrációjú illóolajat tartalmazó tápoldatba helyeztük (lásd 7. táblázat). A kontroll sejtszuszpenzióban nem volt illóolaj. Négyórán keresztül óránkénti mintavétellel meghatároztuk az élelmiszermaradványokat tartalmazó felületeken megtapadt sejtek számát.

\section{Csirkemell lé fehérje-, szénhidrát- és zsírtartalmának meghatározása}

A fehérje meghatározás a csirkemell lében Biuret módszer (Layne, 1957) szerint történt, a teljes szénhidrát tartalom Anthron módszer (Hedge és Hofreiter, 1962) segítségével, míg a zsírtartalom meghatározása a Magyar Szabvány 6830-11:1999 szerint történt petróleum éteres kioldás után. A Biuret-módszer a fehérjék rézionokkal képzett komplexét méri 540 nm-en. A fehérjekoncentrációt marha szérum albumin kalibrációs egyenes segítségével határoztuk meg. Az Anthron-módszernél a cukorkomponensek az Anthron reagenssel kénsavas közegben zöldes-kék színt adnak, melyet 620 nm-en mérhetünk. A kalibrációt glükózra végeztük.

A paradicsompüré adatai a gyártótól származnak és 100 g-ra vonatkoznak: fehérje $1,3 \mathrm{~g}$, szénhidrát $5,3 \mathrm{~g}$, zsír $0 \mathrm{~g}$, só $0,4 \mathrm{~g}$, rost $2 \mathrm{~g}$.

Fehérje kicsapás

Juven és munkatársai (1994) tanulmánya szerint egyes fehérjék képesek megkötni egyes illóolaj komponenseket, így gyöngítik az illóolajok hatását. A fehérjék szerepének vizsgálatához a csirkemell léből és a paradicsomléből 5\% triklór-ecetsavval kicsaptuk a 
fehérjéket, majd 3000 rpm-en 30 percig centrifugáltuk az elegyet. A fehérjementes felülúszókat a már leírtak szerint használtuk a tapadásgátlás vizsgálatokban.

\subsubsection{Illóolajjal bevont felülethez való tapadási képesség vizsgálata}

A vizsgálat során az antimikrobiális bevonattal ellátott felületek mintájára a polipropilén és rozsdamentes acél felületeket illóolajos oldattal vontuk be, amit rászárítottunk egy lamináris boxban. Az illóolajos oldat fiziológiás sóoldatot és 1\% Tween 40-t tartalmazott, valamint fahéj, majoránna vagy kakukkfü illóolajat MBC/2 koncentrációban, amely baktériumonként eltérő volt. Ezután 2-3 x 10 6 CFU/ml baktérium szuszpenzióba helyeztük a lapkákat és a fentebb leírtak alapján (5.6.2. és 5.6.3. fejezet) 4 óra hosszán keresztül néztük a sejtszámot óránként.

\subsubsection{DAPI festés tapadás vizsgálat során}

A rozsdamentes acél felületen megtapadt sejtek megjelenítésére $0,5 \mu \mathrm{g} / \mathrm{ml}$ DAPI (4',6-diamidin-2'-fenilindol-dihidroklorid) (Sigma Aldrich) festéket használtunk. A festés előtt a felületeket leöblítettük steril vízzel, ezután 10 percig festettük a mintákat, majd a felesleges festéket foszfát pufferrel $\left(8 \mathrm{~g} / 1 \mathrm{NaCl}, 0,2 \mathrm{~g} / 1 \mathrm{KCl}, 1,42 \mathrm{~g} / 1 \mathrm{Na}_{2} \mathrm{HPO}_{4}, 0,24 \mathrm{~g} / \mathrm{l}\right.$ $\mathrm{KH}_{2} \mathrm{PO}_{4}$ ) mostuk le. A képalkotás fluoreszcens mikroszkóp segítségével történt (LR 66238C, Carl Zeiss, Axiolab; kamera: AxioCam ERc 5s, Carl Zeiss, Axiolab). A vizsgált polipropilén a felvételek készítése során zavaró hátteret adott, ezért ennél a felületnél a festést nem tudtuk alkalmazni.

\subsection{Illóolajok baktericid kinetikájának meghatározása a koncentráció és pH alapján}

Ebben a kísérletben azt vizsgáltuk, hogy az illóolajok különböző koncentrációban és pH-án hogyan módosítják a pusztulási görbék meredekségét. Célunk volt a 120 percnél rövidebb pusztulási időkhöz tartozó paraméterek megtalálása. Mivel az illóolajok MBC értékét 24 óra után határoztuk meg, ezért szükség volt a koncentráció többszörözésére és/vagy az oldat kémhatásának változtatására. Az irodalmi adatok szerint savas vagy lúgos pH-n az illóolajok hatékonyabbak. Alacsony pH-n az illóolajok hidrofób jellege erösödik, könnyebben átjuthatnak a sejtfalon (Burt, 2004).

A beállított sejtszámú (2-3 x $\left.10^{6} \mathrm{CFU} / \mathrm{ml}\right)$ 18-20 órás tenyészethez hozzáadtuk az illóolajat egyszeres és többszörös MBC koncentrációban. Az illóolaj hozzáadása előtt és utána 5 percenként mintát vettünk és szélesztéssel meghatároztuk az élő sejtszámot 120 percen keresztül. Ezután vizsgáltuk az illóolajat is tartalmazó baktériumszuszpenzió pH 
változásának ( $\mathrm{pH} 4,5 ; 8,5)$ hatását a baktériumok pusztulási idejére. A pH beállítást $0,1 \mathrm{~N}$ nátrium-hidroxiddal vagy ecetsavval végeztük. Előkísérletek alapján a két vizsgált pH (4,5 és 8,5$)$ önmagában nem okozott sejtpusztulást.

\subsection{Biofilmek létrehozása és eliminálása}

A biofilmeket polipropilén és rozsdamentes acél lapkákon hoztuk létre. A 18-20 órás baktériumszuszpenzió sejtszámát hígítással 4-5 x 10 $\mathrm{CFU} / \mathrm{ml}$-re állítottuk be és ebbe merítettük bele és hagytuk állni a lapkákat. A hígító folyadék a baktériumnak megfelelö (lásd 3. táblázat) friss tápoldat volt. A lapkákat 24 vagy 168 óráig hagytuk a szuszpenzióban, ezalatt a feltapadt sejtekből biofilm képződött. Az inkubációt követően a lapkákat steril vízzel leöblítettük a meg nem tapadt sejtek eltávolítása végett, és fertőtlenítő oldatba (illóolaj a megfelelő koncentrációban $+1 \%$ Tween 40 tartalmú fiziológiás sóoldat) helyeztük. A fertőtlenítő oldatokban az illóolaj koncentráció az előző fejezetben megállapított 120 percen belüli pusztulást okozó koncentráció volt. A pusztulási görbékről leolvasott idők a szabad sejtekre vonatkoztak, így megdupláztuk azokat a biofilm teljes eliminálása érdekében. A kontroll oldat csak fiziológiás sóoldatot és 1\% Tween 40-t tartalmazott. A megfelelő fertőtlenítési idő után a lapkákat eltávolítottuk, leöblítettük a felületeket és 5 perc, $50 \mathrm{kHz}$-en való szonikálás után szélesztéssel meghatároztuk a túlélő sejtszámot.

\subsubsection{Biofilmek festése}

A kialakult biofilmeket $0,1 \mathrm{mg} / \mathrm{ml}$ akridin-narancs oldattal festettük meg (Pérez Ibarreche és mtsi., 2014), a festés ideje 20 perc volt. Ezután a lapkákat leöblítettük desztillált vízzel, majd az akridin-naranccsal festett biofilmekröl fluoreszcens mikroszkóp segítségével felvételeket készítettünk (LR 66238C, Carl Zeiss, Axiolab; kamera: AxioCam ERc 5s, Carl Zeiss, Axiolab).

\subsection{Kevert biofilmek eliminálása}

A vegyes tenyészet tagjait 18-20 órás tenyészetekböl kevertük össze 1:1 arányban (végső sejtszám $8 \times 10^{6} \mathrm{CFU} / \mathrm{ml}$ ). Az előkészített, steril fa (nyírfa spatula, Romer, Hollandia), PP, SS, és csempe (Kwadro Ceramica, Magyarország) lapkákat belehelyeztük a sejtszuszpenzióba. A PP, SS és csempe felület előkészítése az 5.6.1. fejezetben leírtak alapján történt, a fa felületet nem kellett zsírtalanítani, mivel gyári új lapkákat használtunk. A lapkákat tartalmazó szuszpenziókat $30^{\circ} \mathrm{C}$-on 24 és 168 óráig inkubáltuk, majd az 5.6.2. fejezetben leírtak szerint fertőtlenítettük, majd meghatároztuk a biofilmben lévő élő 
sejtszámot szélesztéssel. A vegyes populáció egyes tagjainak meghatározására szelektív táptalajokat (lásd 5. táblázat) is használtunk az LB táptalaj mellett. Az illóolajos fertőtlenítő oldat hatását a perecetsav alapú HC-DPE (HungaroChemicals, Magyarország) fertőtlenítőszerrel hasonlítottuk össze. A fertőtlenítőszer alkalmazásának paramétereit a gyártó utasításai szerint állítottuk be: 0,1\%-os koncentráció és 10 perces fertőtlenítési idő. A fertőtlenítési müveleteket szobahőmérsékleten $\left(20-23^{\circ} \mathrm{C}\right)$ végeztük.

Mivel a fa képes magát megszívni nedvességgel, ezért a fa lapkákat csak 10 percig merítettük a sejtszuszpenzióba, majd Petri-csészébe tettük és inkubáltuk $30{ }^{\circ} \mathrm{C}$-on 24 óra hosszáig. A 168 órás biofilm képzésnél a lapkákat minden 2. nap 10 percig friss sejtszuszpenzióba merítettük. A fa felületekkel az otthoni vágódeszka használatát szerettük volna modellezni, mely csak használat közben és mosogatásnál találkozik több nedvességgel.

\subsection{A fertőtlenítőszer optimalizálása}

Az optimális, természetes alapú fertőtlenítőszer kifejlesztéséhez szükséges volt a lehető legalacsonyabb illóolaj koncentráció és a legrövidebb hatóidő meghatározása. A korábbi kísérletek eredményei alapján az optimalizálást 24 órás $E$. coli és $L$. monocytogenes egyfajú biofilmek müanyag felületröl, valamint E. coli, L. monocytogenes, $S$. aureus és $P$. putida kevert tenyészetének fa és müanyag felületről történő eltávolításának 3 paraméteres és 3 szintes kísérlettervezésével végeztük (Box-Behnken Response Surface Design) a Desing Expert 9 programcsomag segítségével. A független változók a koncentráció (A), a hatóidő (B) és a pH (C) voltak. A változók szélső értékeit, az előzetes kísérletek alapján, mi határoztuk meg, míg a program generálta a középértéket. A kísérlettervezés paramétereit a 8. táblázat foglalja össze. A kísérlet során a függő változó a túlélő sejtszám volt. Célunk volt azon paraméterek megtalálása, ahol a felületeken már nem mutatható ki élő sejt. A program alapján egy-egy baktériumra, illetve a vegyes biofilmre felületenként 17 összeállítás/illóolaj készült, melyekben már ott voltak a szükséges ismétlések is. A kísérlet során a 24 órás biofilmet tartalmazó lapkákat a program által meghatározott koncentrációjú, pH-jú oldatba helyeztük a meghatározott ideig, majd öblítést és szonikálást követően szélesztéssel meghatároztuk a túlélő sejtszámot. 
A modell egy másodfokú polinomiális egyenletre épült:

$$
y=\beta_{0}+\beta_{1} A+\beta_{2} B+\beta_{3} C+\beta_{11} A^{2}+\beta_{22} B^{2}+\beta_{33} C^{2}+\beta_{12} A B+\beta_{13} A C+\beta_{23} B C
$$

ahol y a túlélő sejtszám; $\beta_{0}$ az x tengely metszete; $\beta_{1}, \beta_{2}, \beta_{3}$ lineáris koefficiens; $\beta_{11}, \beta_{22}, \beta_{33}$ négyzetes koefficiens; $\beta_{12}, \beta_{13}, \beta_{23}$ interakciós koefficiensek; $A, B, C$ változók. A program az eredményeket az ANOVA statisztikai programmal értékelte.

8. táblázat. A kísérlettervezés paraméterei.

\begin{tabular}{llccccccccc}
\hline \multirow{2}{*}{ Baktérium } & Illóolaj & \multicolumn{3}{c}{ Kakukkfü } & \multicolumn{3}{c}{ Majoránna } & \multicolumn{3}{c}{ Fahéj } \\
\cline { 2 - 11 } & Szint & -1 & 0 & +1 & -1 & 0 & +1 & -1 & 0 & +1 \\
\hline E. coli & $\mathrm{A}(\mathrm{mg} / \mathrm{ml})$ & 1,6 & 3,2 & 4,8 & 1,6 & 3,2 & 4,8 & 0,4 & 0,8 & 1,2 \\
L. monocytogenes & $\mathrm{A}(\mathrm{mg} / \mathrm{ml})$ & 6,3 & 12,5 & 18,9 & 6,3 & 12,5 & 18,9 & 1,6 & 3,2 & 4,8 \\
& $\mathrm{~B}(\mathrm{~min})$ & 10 & 60 & 110 & 10 & 60 & 110 & 10 & 60 & 110 \\
& $\mathrm{C}$ & 4,5 & 6,0 & 7,5 & 4,5 & 6,0 & 7,5 & 4,5 & 6,0 & 7,5 \\
\hline Vegyes & $\mathrm{A}(\mathrm{mg} / \mathrm{ml})$ & 12,5 & 56,25 & 100 & 12,5 & 56,25 & 100 & 1,6 & 7,2 & 12,5 \\
& $\mathrm{~B}(\mathrm{~min})$ & 10 & 20 & 30 & 10 & 20 & 30 & 10 & 20 & 30 \\
& $\mathrm{C}$ & 4,5 & 6,0 & 7,5 & 4,5 & 6,0 & 7,5 & 4,5 & 6,0 & 7,5 \\
\hline
\end{tabular}

A: koncentráció; B: hatóidö; C: $\mathrm{pH}$ (B és $\mathrm{C}$ adatok az E. coli és L. monocytogenes esetén megegyeznek).

Az optimalizálás során kapott statisztikai eredményeket az alábbiak szerint értékeltük: ha a szignifikancia $\mathrm{p}<0,05$ alatt volt, a modell alkalmas optimalizálásra; ha a többszörös korrelációs koefficiens ( $\mathrm{R}^{2}$ : fitness of the model - elfogadhatósági határ) 0,9 feletti értékü, akkor az összefüggés az előrejelzett és a mért értékek között megfelelő volt. $\mathrm{Az}$ adequate precision (zavaró tényezők) 4 feletti értéke azt jelezte, hogy a kapott diagramok használhatóak optimalizálásra. Ha e paraméterek mindegyike megfelelt, akkor az optimalizálás során kapott, adott illóolaj alapú fertőtlenítőoldatot használtuk a továbbiakban.

A kísérlet további részében az optimalizált paraméterek alapján fertőtlenítettük a különböző felületeket, melyeken 24 és 168 órás egyfajú és vegyes populációjú biofilmek voltak (5.8. fejezet alapján). Az optimalizált fertőtlenítőszer hatását összehasonlítottuk az iparban használatos HC-DPE savas fertőtlentőszerrel és az egészségügyben is használatos Brandolin alkoholos felületfertőtlenítő szerrel (Florin Zrt., Szeged; 70\% Etanol).

\subsection{Elektronmikroszkópos vizsgálatok}

Az elektronmikroszkópos vizsgálatok segítségével jól tanulmányozhatók a felületek, illetve a fertőtlenítőszer hatására a baktériumokon bekövetkező változások. A 
kísérlet során mủanyag felületen lévő biofilmeket vizsgáltunk. A minta elökészítése a következő lépésekből állt:

- biofilm képzése a müanyagon (24 és 168 órás) és fertőtlenítés

- a minta fixálása: 2,5\%-os glutáraldehidben (0,05 M kakodilát puffer-7,5 pH) 2 órás inkubáció

- víztelenítés: 50\%, 70\%, 80\%-os etanolban 2x15 percig, majd 96\%-os etanolban 90 percig és 100\%-os etanolban 2 óra hosszáig, ezután t-butilalkohol és 100\% etanol 1:2; 1:1; 2:1 arányú keverékében 1-1 óra hosszáig, végül abszolút t-butil-alkoholban 2 óra hosszáig álltak a lapok

- liofilizáltuk a mintát a teljes kiszáradás elérése érdekében (kb. 4-6 óra)

- minta rögzítése a mintatartóra ezüstpaszta segítségével

- a mintát arany membránnal vontuk be és a Hitachi S4700 pásztázó elektronmikroszkóppal felvételeket készítettünk.

\subsection{Statisztikai analízis}

A különböző kezelések és az optimalizálás során kapott eredményeket egyutas ANOVA programmal ( $\mathrm{R}$ software, $\mathrm{R}$ version 3.1.1) értékeltük ki, és középértékek közti különbséget Tukeys teszttel vizsgáltuk. A különbséget szignifikánsnak tekintettük, ha a pérték kisebb volt 0,05-nál. 


\section{Eredmények és értékelésük}

\subsection{Az élelmiszeripari üzemekben izolált baktériumok azonosítása}

Az élelmiszeripari izolálást, PCR-rel való felamplifikálást és baktériumok szekvenciáinak beazonosítását követően az alábbi baktériumokat azonosítottuk Pseudomonas sp., Enterobacter sp., Escherichia sp., Citrobacter sp., Serratia sp., melynek izolálási helyét a 9. táblázat tartalmazza. A fajszintü meghatározásra nem kaptunk megbízható eredményeket, így csak nemzetség szinten tudtuk meghatározni az izolátumokat. A PCR során kapott génfragmentek 500-600 kilobázispár között voltak. A PCR termékek agaróz gélelektroforézisének eredményét a 3. ábra mutatja be.

9. táblázat. Azonosított baktériumok a származási felület megnevezésével.

\begin{tabular}{lll}
\hline Minta kódja & Felület megnevezése & Baktériumok megnevezése \\
\hline Vágóhíd & & \\
V1 & Felsőpálya horog & Citrobacter sp. $(100 \%)$ \\
V2 & Feldolgozó-asztal & Serratia sp. $(100 \%)$ \\
\hline Péksütemény gyártó & \\
P1 & Tojáscső & Enterobacter sp. $(100 \%)$ \\
P2 & Mérleg & Escherichia sp. $(100 \%)$ \\
P3 & Szállítószalag & Pseudomonas sp. $(100 \%)$ \\
\hline
\end{tabular}

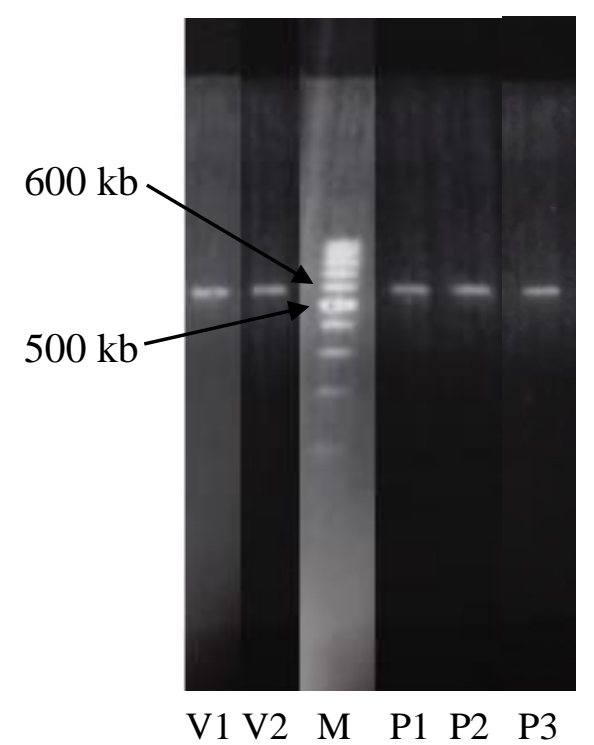

3. ábra. Az izolált baktériumok PCR termékei az azonosított baktérium nemzetségek jelölésével. M-marker, V1 Citrobacter sp., V2 Serratia sp., P1 Enterobacter sp., P2 Escherichia sp., P3 Pseudomonas sp. 
Az azonosított Escherichia, Serratia, Enterobacter és Citrobacter nemzetségekbe tartozó izolátumok Gram-negatív baktériumok, ezek közül az Enterobacteriaceae családba tartozó coliformok szinte minden élelmiszert képesek szennyezni és ezáltal betegséget okozni (Deák és mtsi., 2006; Guentzel, 1996). A 4/1998 EüM rendelet értelmében a csomagoló anyagokon és a személyi higiéniás vizsgálat során nem lehet jelen Enterobacteriaceae családba tartozó baktérium.

\subsection{Az alkalmazott illóolajok MIC és MBC értékeinek meghatározása}

A kísérletek elején meghatároztuk mikrodilúciós kísérletekkel az illóolajok MIC és MBC értékeit az SZMC törzsgyüjteményből származó baktériumokon, vegyes tenyészeten és az élelmiszeripari üzemekből izolált baktériumok esetében. Az eredményeket a 10. táblázatban mutatjuk be. A vizsgált illóolajok közül három illóolaj mutatkozott ígéretesnek, ezek a fahéj-, a majoránna- és kakukkfüolaj. A fahéj illóolaj esetében kaptuk a legkisebb MBC értékeket (10. táblázat). Az eredmények összehasonlítása más kutatások eredményeivel nem egyszerű a különböző módszerek és az eltérő illóolaj összetétel miatt.

A legkevésbé hatásos a citrom illóolaj volt, ahol a legtöbb esetben a MIC és MBC értékek $100 \mathrm{mg} / \mathrm{ml}$ fölé estek (10. táblázat). Desai és munkatársai (2012) tanulmánya során a citrom illóolaj szintén hatástalannak bizonyult a baktériumok ellen.

A 10. táblázatban jól látható, hogy összességében az általunk vizsgált baktériumokra is igaz az a teória, hogy a Gram-negatív baktériumok kevésbé érzékenyek az illóolajokra, mint a Gram-pozitív baktériumok. A legérzékenyebb a B. subtilis volt, míg a $P$. putida volt a legellenállóbb baktérium, mivel az illóolajok többsége nem befolyásolta a növekedését. A két Bacillus faj illóolajokkal szembeni érzékenységében különbséget tapasztaltunk, melyre magyarázat lehet Anderson és munkatársai (2005) megállapítása, hogy a B. cereus és B. subtilis másképp viselkedik stresszhelyzetben. 
10. táblázat. A vizsgált illóolajok MIC és MBC értékei (mg/ml).

\begin{tabular}{|c|c|c|c|c|c|c|c|c|c|c|c|c|}
\hline \multirow{2}{*}{$\begin{array}{l}\text { Illóolaj } \\
\text { Baktériumok a } \\
\text { törzsgyüjteményböl }\end{array}$} & \multicolumn{2}{|c|}{ Kakukkfü } & \multicolumn{2}{|c|}{ Majoránna } & \multicolumn{2}{|c|}{ Fahéj } & \multicolumn{2}{|c|}{$\begin{array}{c}\text { Muskotály- } \\
\text { zsálya }\end{array}$} & \multicolumn{2}{|c|}{ Boróka } & \multicolumn{2}{|c|}{ Citrom } \\
\hline & $\stackrel{U}{\Sigma}$ & $\stackrel{v}{\sum}$ & $\stackrel{\cup}{\Sigma}$ & $\sum_{i}^{U}$ & $\stackrel{\cup}{\Sigma}$ & $\sum_{\Sigma}^{\cup}$ & $\stackrel{U}{\Sigma}$ & $\stackrel{\cup}{\sum}$ & $\stackrel{\cup}{\Sigma}$ & $\stackrel{v}{\sum}$ & $\stackrel{U}{\Sigma}$ & $\sum_{\Sigma}^{\cup}$ \\
\hline E. coli & 1,6 & 1,6 & 1,6 & 1,6 & 0,2 & 0,4 & 60,0 & 70,0 & 6,3 & 25,0 & $>100$ & $>100$ \\
\hline P. putida & $>100$ & $>100$ & 3,2 & 6,3 & 0,8 & 0,8 & 6,3 & 12,5 & $>100$ & $>100$ & $>100$ & $>100$ \\
\hline B. cereus & 1,6 & 3,2 & 1,6 & 3,2 & 0,2 & 0,4 & 6,3 & 12,5 & 6,3 & 6,3 & 100 & $>100$ \\
\hline B. subtilis & 0,8 & 1,6 & 1,6 & 3,2 & 0,4 & 0,4 & 0,8 & 1,6 & 3,2 & 6,3 & 3,2 & 3,2 \\
\hline L. monocyto & 3,2 & 6,3 & & 6,3 & 0,8 & 1,6 & 100 & $>100$ & 12,5 & 50,0 & $>100$ & $>100$ \\
\hline MSSA & 0,8 & 1,6 & 3,2 & 6,3 & 0,4 & 0,8 & 25,0 & 50,0 & 3,2 & 6,3 & 12,5 & $>100$ \\
\hline MRSA & 3,2 & 12,5 & 3,2 & 6,3 & 1,6 & 3,2 & 6,3 & 12,5 & 3,2 & 6,3 & $>100$ & $>100$ \\
\hline Vegyes populáció & 3,2 & 12,5 & 6,3 & 12,5 & 0,8 & 1,6 & 50,0 & $>100$ & $>100$ & $>100$ & 100 & $>100$ \\
\hline \multicolumn{13}{|l|}{ Iparból izolált törzsek } \\
\hline Citrobacter sp. & 0,2 & 3,2 & 3,2 & 12,5 & 0,8 & 1,6 & 50,0 & 100 & 50,0 & 100 & $>100$ & $>100$ \\
\hline Serratia sp. & 100 & $>100$ & 12,5 & 50,0 & 0,8 & 3,2 & 50,0 & $>100$ & $>100$ & $>100$ & $>100$ & $>100$ \\
\hline Enterobacter sp. & 0,2 & 1,6 & 1,6 & 25,0 & 0,2 & 3,2 & 25,0 & 100 & 100 & $>100$ & $>100$ & $>100$ \\
\hline Escherichia sp. & 3,2 & 6,3 & 12,5 & 50,0 & 0,8 & 3,2 & $>100$ & $>100$ & $>100$ & $>100$ & $>100$ & $>100$ \\
\hline Pseudomonas sp. & 1,6 & 3,2 & 6,3 & 50,0 & 0,4 & 6,3 & 50,0 & 100 & 100 & $>100$ & $>100$ & $>100$ \\
\hline
\end{tabular}

Az iparból izolált baktériumok ellenállóbbak voltak, mint a törzsgyüjteményből származók. Megfigyeltük, hogy a vegyes tenyészet (E. coli, P. putida, S. aureus, L. monocytogenes 1:1 arányban) esetén az illóolajok MBC értékei gyakran azonosak voltak a legellenállóbb baktériumnál tapasztalt MBC értékkel.

Az antibiotikum rezisztens és érzékeny $S$. aureus törzsek eltérő érzékenységet mutattak az illóolajok esetén is. Az MRSA rezisztens volt a fahéjolajra és a kakukkfüolajra, míg a muskotályzsálya-olajra igen érzékeny volt, szemben az MSSA-val. Warnke és munkatársai (2009) kimutatták, hogy a fahéjolaj egyenlően hatott a két típusra, míg a fehér kakukkfüolaj, a teafaolaj és a citromfüolaj jobban hatott az MRSA-ra.

A kevésbé vizsgált boróka illóolaj esetén eredményeink alapján megállapítottuk, hogy a Gram-pozitív baktériumok kevésbé ellenállók vele szemben, mint a Gram-negatív baktériumok, kivéve a L. monocytogenes-t, ahol a többihez képest csak két-három nagyságrenddel nagyobb borókaolaj koncentráció (MIC: 12,5 mg/ml) eredményezett teljes növekedésgátlást. Rusenova és Parvanov (2009) kutatásaik során a kakukkfü-, majoránna-, fahéj- és muskotályzsálya illóolajok közül a legnagyobb MIC értéket a muskotályzsályaolaj esetén kapták, míg fahéjolaj alkalmazásakor kapták a legkisebb MIC értékeket. Ez a 
megállapítás az általunk vizsgált baktériumok többségére is igaz, azaz a muskotályzsályaolajra voltak a legkevésbé érzékenyek a citrom illóolaj után.

Penna és munkatársai (2001) a perecetsav és a hidrogén-peroxid hatását vizsgálták E. coli és $S$. aureus baktériumoknál. Ezek a szerek ma is az ipari fertőtlenítőszerek fő összetevői. A kísérlet során 2,3 és $4,6 \mathrm{mg} / \mathrm{ml}$ perecetsav, illetve 2,5 és $0,94 \mathrm{mg} / \mathrm{ml}$ hidrogén-peroxid alkalmazása eredményezte a baktériumok elpusztítását. Az illóolajok (majoránna, kakukkfü, fahéj) alkalmazásával kisebb koncentrációkkal tudtuk ugyanezt a hatást elérni, ez alapján ezek az illóolajok megfelelő alternatívái lehetnek a jelenleg alkalmazott fertőtlenítőszereknek. A boróka-, citrom- és muskotályzsálya illóolajat kizártuk a további vizsgálatainkból a magas MBC értékek miatt.

\subsection{Az illóolajok közötti kölcsönhatások vizsgálata}

A MIC értékek megállapítása után a továbbiakban már csak a hatékonynak bizonyuló fahéj-, kakukkfü- és majoránna illóolajokkal dolgoztunk tovább. A sakktábla módszer alapján vizsgáltuk az illóolajok között kialakuló kölcsönhatások típusát. Az eredményeket a 11. táblázatban mutatjuk be, ezek alapján elmondható, hogy azon keverékek bizonyultak hatásosabbnak, melyekben fenolos vegyület is található (pl. kakukkfüolaj), ahol a FICI 1 vagy az alatt volt.

Egyöntetü eredményről nem lehet beszélni, mivel a baktériumok különböző választ adtak a keverékekre. Szinergizmust a Bacillus fajoknál és a L. monocytogenes esetén tapasztaltunk a fahéj-kakukkfü illóolajok és a majoránna-kakukkfü illóolajok között, míg jelentős mértékü indifferens hatást az Enterobacter izolátum esetében. Elmondhatjuk, hogy a törzsgyüjteményből származó baktériumok esetén az E. coli-n kívül mindenhol csökkenteni tudtuk a teljes növekedésgátlást eredményező illóolajok mennyiségét a kombinációban, míg az ipari izolátumok esetén ez nem sikerült. Itt is látható, hogy másképp reagálnak az azonos nemzetségbe tartozó baktériumok is, mivel az iparból izolált Escherichia törzs érzékenyebb volt a majoránnaolaj-fahéjolaj vagy a kakukkfüolajfahéjolaj keverékekre, mint a törzsgyüjteményből származó E. coli. A 11. táblázat adatai jól tükrözik, hogy általánosságban nem csak az egyes illóolajokkal szemben ellenállóbbak a Gram-negatív fajok, hanem az illóolaj keverékekkel szemben is.

Pei és munkatársai (2009), Bajpai és munkatársai (2012) és Bassolé és Juliani (2012) összefoglalói is alátámasztja az eredményeinket, miszerint a fahéjaldehid (fahéjolaj) és timol (kakukkfüolaj) keveréke esetén érhető el szinergizmus. 
11. táblázat. Az illóolajok közötti kölcsönhatás vizsgálatok eredményei.

\begin{tabular}{|c|c|c|c|}
\hline \multirow[t]{2}{*}{ Baktériumok } & $\begin{array}{l}\text { Majoránnaolaj- } \\
\text { kakukkfúolaj }\end{array}$ & $\begin{array}{l}\text { Majoránnaolaj- } \\
\text { fahéjolaj }\end{array}$ & $\begin{array}{c}\text { Kakukkfüolaj- } \\
\text { fahéjolaj }\end{array}$ \\
\hline & FICI & FICI & FICI \\
\hline E. coli & 1,5 & 2 & 5 \\
\hline P. putida & - & 1,06 & - \\
\hline B.cereus & 0,18 & 0,62 & 0,31 \\
\hline B. subtilis & 0,31 & 0,62 & 0,41 \\
\hline L. monocytogenes & 0,18 & 0,65 & 0,31 \\
\hline MSSA & 1,12 & 1 & 0,75 \\
\hline MRSA & 1 & 1 & 1 \\
\hline Vegyes populáció & 1 & 0,75 & 1,25 \\
\hline Citrobacter sp. & 2 & 4 & 2 \\
\hline Serratia sp. & - & 1 & - \\
\hline Enterobacter sp. & 4 & 4 & 4 \\
\hline Escherichia sp. & 1,5 & 1,06 & 2,25 \\
\hline Pseudomonas sp. & 2,06 & 2,06 & 4 \\
\hline
\end{tabular}

Rózsaszín kiemelés: szinergizmus (FICI $<0,5)$; sárga kiemelés: additív hatás $(0,5 \leq$ FICI $\leq 1)$; nincs kiemelés: indifferens hatás $1<$ FICI $\leq 4$; antagonista hatás FICI $>4$ - nem végeztük kölcsönhatás vizsgálatot, mert az egyik illóolajra a MIC nagyobb volt, mint $100 \mathrm{mg} / \mathrm{ml}$.

\subsection{Tapadás vizsgálat eredményei illóolajos közegben}

A tapadás során a baktérium szuszpenzióból kitapadt sejtek számát a polipropilén és rozsdamentes acél felületeken a 12-14. táblázatok mutatják be, amelyben az első óra végére megtapadt sejtek számát és a 4. és 1. óra végén mért sejtszámok közötti különbséget tüntettük fel. Ha ez a különbség pozitív volt, az azt jelentette, hogy a megtapadt sejtek száma nőtt az idővel, a negatív előjelü számok sejtpusztulásra vagy az irreverzibilis kötődés elmaradására engednek következtetni. Az első esetben valószínüleg már az első óra végén megtörtént az irreverziblis kötődés és a sejtszám növekedését a letapadt sejtek osztódása, mikrotelep képzése okozta.

Összességében elmondható, hogy a kontrollnál (szuszpenzió nem tartalmazott illóolajat) nincs jelentős különbség a két felülethez való tapadás között (12. táblázat). A kakukkfüolaj mindkét felületen teljes mértékben gátolta az $E$. coli, az MRSA és a $L$. monocytogenes tapadását, míg az MSSA esetében csak az acél felületre történő kitapadást gátolta. A kakukkfüolaj egyik fö összetevője a p-cimén, amely képes csökkenteni a sejtmozgást (Hyldgaard és mtsi., 2012; Nazzaro és mtsi., 2013), melynek szerepe van a reverzibilis tapadásnál (Hori és Matsumoto, 2010; Petrova és Sauer, 2012). A 
majoránnaolaj szintén teljes tapadásgátlást okozott a $P$. putida esetében, míg a többi baktériumnál csak az acélon való megtapadást gátolta. Az egyébként igen jó antimikrobiális hatással rendelkező fahéjolaj csak az acélon való kitapadást gátolta $E$. coli és az MRSA esetében, a többi baktériumnál vagy nem tapasztaltunk gátlást vagy a kezdeti gátlás után a sejtek adaptálódtak és képesek voltak a felülethez kötődni. A fahéj illóolaj összeségében csak csökkentette a megtapadt sejtek számát.

A Gram-pozitív MSSA bizonyult a legellenállóbbnak az illóolajokkal szemben, míg az MRSA esetében az illóolajok jobban hatottak (12. táblázat).

A Bacillus fajok a vizsgált idő alatt valószínüleg nem voltak képesek irreverzibilis kötődést kialakítani a felületen, egy általános öblítés eltávolította a sejteket a felületről, mivel a kezeletlen kontrollnál sem tudtunk sejtszámot meghatározni.

12. táblázat. Rozsdamentes acél és polipropilén felületen megtapadt törzsgyüjteményböl származó baktériumok száma $\left(\log \mathrm{CFU} / \mathrm{cm}^{2}\right)$ az első óra végén, és a különbség a 4 . és az 1 . óra végén mért sejtszám között $\left(\Delta, \log \mathrm{CFU} / \mathrm{cm}^{2}\right)$.

\begin{tabular}{llcccc}
\hline Baktérium & Felület & \multicolumn{2}{c}{ Rozsdamentes acél } & \multicolumn{2}{c}{ Polipropilén } \\
\hline E. coli & & 1. óra & $\Delta$ & 1. óra & $\Delta$ \\
& kontroll & ND & $+3,23$ & $3,18 a$ & $+1,34 a^{*}$ \\
& kakukkfúolaj & ND & ND & ND & ND \\
& majoránnaolaj & ND & ND & $3,21 \mathrm{a}$ & $-0,46 \mathrm{~b}$ \\
& fahéjolaj & ND & ND & $2,95 \mathrm{~b}$ & $+0,41 \mathrm{c}$ \\
\hline P. putida & kontroll & $3,61 a$ & $+0,20 a$ & 3,08 & $+1,77 a^{*}$ \\
& majoránnaolaj & ND & ND & ND & ND \\
& fahéjolaj & $2,93 \mathrm{~b}$ & $-0,52 \mathrm{~b}$ & $\mathrm{ND}$ & $+2,49 \mathrm{~b}$ \\
\hline S. aureus & kontroll & $3,23 a$ & $+0,92 a$ & $3,77 a$ & $+0,34 a$ \\
& kakukkfúolaj & ND & ND & $3,19 \mathrm{~b}$ & $-0,53 \mathrm{~b}$ \\
& majoránnaolaj & ND & ND & $2,75 \mathrm{c}$ & $-0,63 \mathrm{~b}$ \\
& fahéjolaj & $3,12 \mathrm{a}$ & $+0,97 \mathrm{a}$ & $3,32 \mathrm{~b}$ & $+0,44 \mathrm{a}$ \\
\hline MRSA & kontroll & 3,43 & $+1,02$ & $3,21 a$ & $+1,19 a$ \\
& kakukkfúolaj & ND & ND & ND & ND \\
& majoránnaolaj & ND & ND & $3,33 \mathrm{a}$ & $-0,41 \mathrm{~b}$ \\
& fahéjolaj & ND & ND & $3,39 \mathrm{a}$ & $+0,35 \mathrm{c}$ \\
\hline L. monocytogenes & kontroll & 3,47 & $+0,33 a$ & $3,70 a$ & $+1,04 a$ \\
& kakukkfúolaj & ND & ND & ND & ND \\
& majoránnaolaj & ND & ND & $3,46 \mathrm{~b}$ & $+0,29 \mathrm{~b}$ \\
& fahéjolaj & ND & $+2,15 \mathrm{~b}$ & $3,68 \mathrm{a}$ & $-0,56 \mathrm{c}$ \\
\hline
\end{tabular}

ND: nem detektálható feltapadt baktérium a felületen;

A különböző kisbetük az egy baktériumra vonatkozó kezelések (beleértve a kontrollt is) közötti szignifikáns eltéréseket mutatják $(\mathrm{p}<0,05)$

*: a szignifikáns különbséget mutatja a két felülethez való tapadás között $(\mathrm{p}<0,05)$.

A 12. táblázat alapján megállapítható, hogy az illóolajok rozsdamentes acélon jobban tudták befolyásolni a tapadást. Ennek hátterében a felületek és az illóolajok 
hidrofób tulajdonságai állhatnak, illetve a befolyásolhatja a felületi érdesség is, mégpedig minél érdesebb egy felület, annál könnyebb rajta a baktériumok megtapadása.

Vegyes tenyészet (E. coli, L. monocytogenes, $P$. putida és $S$. aureus kevert tenyészete) esetén is hasonló megállapításra jutottunk, miszerint nincs szignifikáns különbség a két felületre kitapadt baktérium sejtszám között a kontrollok esetében (p>0,05). Mindegyik illóolaj csökkentette a baktériumok tapadási képességét, de egyik sem okozott teljes gátlást, mutatva, hogy a kevert tenyészetek ellenállóbbak a külső hatásokkal szemben, mint a monotenyészetek (13. táblázat).

13. táblázat. Rozsdamentes acél és polipropilén felületen megtapadt kevert tenyészet sejtszáma $\left(\log C F U / \mathrm{cm}^{2}\right)$ az első óra végén, és a különbség a 4 . és az 1. óra végén mért sejtszám között $\left(\Delta, \log \mathrm{CFU} / \mathrm{cm}^{2}\right)$.

\begin{tabular}{lcccc}
\hline Felület & \multicolumn{2}{c}{ Rozsdamentes acél } & \multicolumn{2}{c}{ Polipropilén } \\
\hline & 1. óra & $\Delta$ & 1. óra & $\Delta$ \\
\hline Kontroll & $4,72 \mathrm{a}$ & $+0,60 \mathrm{a}$ & $4,95 \mathrm{a}$ & $+0,45 \mathrm{a}$ \\
Kakukkfüolaj & $3,49 \mathrm{~b}$ & $+0,47 \mathrm{~b}$ & $3,77 \mathrm{~b}$ & $+0,58 \mathrm{~b}$ \\
Majoránnaolaj & $3,25 \mathrm{~b}$ & $+0,21 \mathrm{c}$ & $3,23 \mathrm{c}$ & $+0,16 \mathrm{c}$ \\
Fahéjolaj & $3,70 \mathrm{c}$ & $+0,26 \mathrm{~d}$ & $3,81 \mathrm{~b}$ & $+0,25 \mathrm{~b}$
\end{tabular}

A különböző kisbetük az egy baktériumra vonatkozó kezelések (beleértve a kontrollt is) közötti szignifikáns eltéréseket mutatják $(\mathrm{p}<0,05)$.

A 14. táblázat az ipari üzemekböl izolált törzsekkel végzett kísérletek eredményeit mutatja be. Ezeknél sem tapasztaltunk különbséget a két felülethez történő kapcsolódásban, még az Escherichia izolátum esetében sem, ahol feltételeztük, hogy hasonlóan fog viselkedni, mint a törzsgyüjteményből származó E. coli. Kivétel nélkül minden illóolaj szignifikánsan csökkentette a megtapadt sejtek számát a kontrollhoz képest $(\mathrm{p}<0,05)$ a negyedik óra végére. A majoránna illóolaj az Escherichia és a Pseudomonas izolátumnál a kezdeti tapadást több mint egy nagyságrenddel csökkentette és a letapadt Escherichia sejtek szaporodását is gátolta. Egyik illóolajjal sem sikerült elérnünk az izolátumok tapadásának teljes gátlását.

A tapadási kísérletből látszik, hogy az illóolajok hatása baktériumfüggő volt és kevésbé függött a felülettől. A különbség a baktériumok adaptációs képességében lehet, és az eredménynek alapján azt feltételezzük, hogy az ipari izolátumok jobb adaptációs képességgel rendelkeznek. 
14. táblázat. Rozsdamentes acél és polipropilén felületen megtapadt izolátumok sejtszáma $\left(\log C F U / \mathrm{cm}^{2}\right)$ az első óra végén, és a különbség a 4. és az 1. óra végén mért sejtszám között $\left(\Delta, \log \mathrm{CFU} / \mathrm{cm}^{2}\right)$.

\begin{tabular}{lllccc}
\hline Felület & & \multicolumn{2}{c}{ Rozsdamentes acél } & \multicolumn{2}{c}{ Polipropilén } \\
\hline Baktérium & & 1. óra & $\Delta$ & 1. óra & $\Delta$ \\
\hline Citrobacter sp. & kontroll & $4,21 \mathrm{a}$ & $+0,86 \mathrm{a}$ & $4,26 \mathrm{a}$ & $+0,85 \mathrm{a}$ \\
& kakukkfüolaj & $3,74 \mathrm{~b}$ & $+0,37 \mathrm{~b}$ & $3,76 \mathrm{~b}$ & $+0,37 \mathrm{~b}$ \\
& majoránnaolaj & $3,77 \mathrm{~b}$ & $+0,06 \mathrm{c}$ & $3,73 \mathrm{~b}$ & $+0,17 \mathrm{c}$ \\
& fahéjolaj & $3,82 \mathrm{~b}$ & $+0,04 \mathrm{c}$ & $3,74 \mathrm{~b}$ & $+0,16 \mathrm{c}$ \\
\hline Escherichia sp. & kontroll & $3,64 \mathrm{a}$ & $+0,73 \mathrm{a}$ & $3,84 \mathrm{a}$ & $+0,75 \mathrm{a}$ \\
& kakukkfüolaj & $3,52 \mathrm{a}$ & $+0,45 \mathrm{~b}$ & $3,50 \mathrm{~b}$ & $+0,57 \mathrm{~b}$ \\
& majoránnaolaj & $2,97 \mathrm{~b}$ & $-0,48 \mathrm{c}$ & $3,05 \mathrm{c}$ & $-0,41 \mathrm{c}$ \\
& fahéjolaj & $3,71 \mathrm{a}$ & $+0,24 \mathrm{~b}$ & $3,71 \mathrm{a}$ & $+0,24 \mathrm{~b}$ \\
\hline \multirow{2}{*}{ Enterobacter sp. } & kontroll & $4,27 \mathrm{a}$ & $+0,74 \mathrm{a}$ & $4,29 \mathrm{a}$ & $+0,73 \mathrm{a}$ \\
& kakukkfüolaj & $4,03 \mathrm{~b}$ & $+0,18 \mathrm{~b}$ & $4,05 \mathrm{~b}$ & $+0,16 \mathrm{~b}$ \\
& majoránnaolaj & $3,80 \mathrm{c}$ & $+0,24 \mathrm{c}$ & $3,80 \mathrm{c}$ & $+0,24 \mathrm{c}$ \\
& fahéjolaj & $3,34 \mathrm{~d}$ & $+0,73 \mathrm{~b}$ & $3,87 \mathrm{c}$ & $+0,58 \mathrm{~b}$ \\
\hline Pseudomonas sp. & kontroll & $4,05 \mathrm{a}$ & $+0,73 \mathrm{a}$ & $4,06 \mathrm{a}$ & $+0,78 \mathrm{a}$ \\
& kakukkfüolaj & $4,00 \mathrm{a}$ & $+0,30 \mathrm{~b}$ & $4,07 \mathrm{a}$ & $+0,23 \mathrm{~b}$ \\
& majoránnaolaj & $2,25 \mathrm{~b}$ & $+0,75 \mathrm{c}$ & $3,01 \mathrm{~b}$ & $+0,12 \mathrm{c}$ \\
& fahéjolaj & $3,26 \mathrm{c}$ & $+0,48 \mathrm{~d}$ & $3,74 \mathrm{c}$ & $+0,13 \mathrm{~d}$ \\
\hline Serratia sp. & kontroll & $4,74 \mathrm{a}$ & $+0,39 \mathrm{a}$ & $4,75 \mathrm{a}$ & $+0,48 \mathrm{a}$ \\
& majoránnaolaj & $3,83 \mathrm{~b}$ & $+0,36 \mathrm{~b}$ & $4,01 \mathrm{~b}$ & $+0,43 \mathrm{~b}$ \\
& fahéjolaj & $3,07 \mathrm{c}$ & $+0,52 \mathrm{c}$ & $3,26 \mathrm{c}$ & $+0,52 \mathrm{c}$ \\
\hline
\end{tabular}

A különböző kisbetűk az egy baktériumra vonatkozó kezelések (beleértve a kontrollt is) közötti szignifikáns eltéréseket mutatják ( $\mathrm{p}<0,05)$.

Egyértelmű magyarázatot nem találtunk az irodalomban arra vonatkozólag, hogy az illóolajok hogyan képesek befolyásolni a baktériumok kitapadását. Feltételezésünk szerint, az illóolajok többféleképpen is befolyásolják a sejteket, egyrészt a homeosztázisukat zavarhatják meg, ezáltal a baktériumok nem a felülethez való kötődésre fogják az energiájuka használni, hanem saját életfenntartásukra. Nazzaro és munkatársai (2013) szerint szubletális koncentrációban alkalmazva az illóolajok az energiatermelés során megzavarják az enzimek müködését. An és Friedman (1998) tanulmányukban azt a megállapítást tették, hogy a megtapadás energiaigényes folyamat, így a felhalmozott ATP készlet is kimerül, mely egyik oka lehet a tapadásgátlásnak, mivel az illóolajok csökkentik az ATP termelést. További magyarázat lehet az is, hogy az illóolaj reakcióba lép a membrán- és citoplazma fehérjékkel, így megváltoztatja a membrán szerkezetét, ezáltal a tapadási folyamatokat is. 


\subsection{Tapadás vizsgálat eredményei élelmiszermaradványt tartalmazó felületen}

A különböző felületekre szárított paradicsompüré és csirkemell lé esetén is vizsgáltuk a baktériumok kitapadását illóolajos közegben. Eredményeink alapján a különböző élelmiszermaradványok elösegítik a baktériumok megtapadását a használt felületeken, mivel extra tápanyagforrásként vagy ragasztóanyagként szolgálnak. Petrova és Sauer (2012) összefoglalója szerint a felületeken található kondicionáló réteg (fehérje, szénhidrát, egyéb molekulák a környezetből) energiaforrásként szolgálhat a baktériumok számára és segíti a kitapadásukat.

$\mathrm{Az}$ eredmények értelmezéséhez először megállapítottuk a tízszeresére kihígított csirkemell lé összetételét, amely a következő volt: a fehérje $0,97 \mathrm{~g}$, a zsír 4,51 g és a glükózban kifejezett szénhidrát $0,53 \mathrm{~g}$ volt 100 g-ban. Ezután értékeltük az izolátumok élelmiszermaradványt tartalmazó felületekhez történő kitapadását, amelyet a 15. táblázat mutat be, és az első szembetünő különbség az előző vizsgálatokhoz képest az volt, hogy a törzsgyüjteményből származó baktériumok esetén, az MRSA és a Bacillus fajok kivételével, nem tapasztaltunk teljes tapadásgátlást, azaz az élelmiszermaradványok egyértelmủen javították a baktériumok megkötődését a felületeken. Az illóolaj-mentes közegből még a Bacillus fajok is képesek voltak kismértékủ kitapadásra, igaz, illóolajok alkalmazásával ez a kismértékü kitapadás is gátolható volt. A legtöbb esetben a csirkemell lé vékony rétege jobban elősegítette a tapadást, mint a paradicsomlé, kivéve az E. coli esetében, ahol a paradicsomos felületre több sejt tapadt ki (15. táblázat).

A két $S$. aureus esetén megállapítottuk, hogy az MRSA tapadását az illóolajok jobban gátolták, mint az MSSA-ét (15. táblázat). MRSA esetén egyértelműen kimondható, hogy a kakukkfüolaj és a majoránnaolaj gátolta a megtapadást a magasabb szénhidráttartalmú közegben (paradicsom). Ez a 4. ábrán is jól látható, mivel a 4. óra végére már nem volt megtapadt sejt a felületen. A fahéj illóolajnak csak tapadást csökkentő hatása volt. Fisher és Phillips (2006) kísérletükben csirkebőrön és káposztalevélen vizsgálták az illóolajok és komponenseik hatását és megállapították, hogy bergamott illóolaj és a citrál komponens alkalmazásakor a $S$. aureus sejtek nagyobb számban voltak jelen csirkebőrön, mint a káposztalevélen a kezelések hatására, míg ez fordított volt $E$. coli és L. monocytogenes baktériumoknál. Szerintük az illóolajok ilyen módon való tartósító hatása szerfüggő és baktériumfüggő is. 
15. táblázat. Élelmiszermaradványokat tartalmazó rozsdamentes acél és polipropilén felületen megtapadt törzsgyüjteményből származó baktériumok száma $\left(\log \mathrm{CFU} / \mathrm{cm}^{2}\right)$ az első óra végén, és a különbség a 4. és az 1. óra végén mért sejtszám között $(\Delta, \log$ $\left.\mathrm{CFU} / \mathrm{cm}^{2}\right)$.

\begin{tabular}{|c|c|c|c|c|c|c|c|c|c|}
\hline \multirow{3}{*}{ Felület } & & \multicolumn{4}{|c|}{ Csirkemell } & \multicolumn{4}{|c|}{ Paradicsompüré } \\
\hline & & \multicolumn{2}{|c|}{ Rozsdamentes acél } & \multicolumn{2}{|c|}{ Polipropilén } & \multicolumn{2}{|c|}{ Rozsdamentes acél } & \multicolumn{2}{|c|}{ Polipropilén } \\
\hline & & 1. óra & $\Delta$ & 1. óra & $\Delta$ & 1. óra & $\Delta$ & 1. óra & $\Delta$ \\
\hline \multirow[t]{4}{*}{ E. coli } & kont & $3,54 a$ & $+0,85 a$ & $3,67 a$ & $+0,89 a$ & $4,54 a$ & $+0,86 a$ & $4,22 a$ & $+0,88 a^{* \#}$ \\
\hline & $\mathrm{kf}$ & $3,24 b$ & $+0,43 \mathrm{~b}$ & $3,26 \mathrm{~b}$ & $-0,36 b$ & $4,44 \mathrm{a}$ & $+0,97 \mathrm{a}$ & $3,96 \mathrm{~b}$ & $+1,07 \mathrm{a}$ \\
\hline & maj & $3,02 \mathrm{c}$ & $-0,49 \mathrm{c}$ & $2,94 \mathrm{c}$ & $+0,05 \mathrm{c}$ & $4,68 \mathrm{a}$ & $+0,14 \mathrm{~b}$ & $4,35 \mathrm{a}$ & $+0,21 \mathrm{~b}$ \\
\hline & fah & $3,45 \mathrm{a}$ & $+0,33 \mathrm{~b}$ & $3,63 \mathrm{~d}$ & $-0,32 \mathrm{~d}$ & $4,28 \mathrm{~b}$ & $+0,80 \mathrm{~b}$ & $4,02 \mathrm{~b}$ & $+0,95 \mathrm{a}$ \\
\hline \multirow[t]{3}{*}{ P. putida } & kont & $4,79 a$ & $+0,32 a$ & $4,74 a$ & $+0,24 a$ & $4,53 a$ & $+0,48 a$ & $4,37 a$ & $+0,35 a^{*}$ \\
\hline & maj & $4,16 \mathrm{~b}$ & $+0,82 \mathrm{~b}$ & $4,14 \mathrm{~b}$ & $+0,78 \mathrm{a}$ & $4,32 \mathrm{~b}$ & $+0,54 \mathrm{a}$ & $4,11 \mathrm{~b}$ & $+0,55 \mathrm{a}$ \\
\hline & fah & $3,03 \mathrm{c}$ & $+0,72 \mathrm{c}$ & $4,11 \mathrm{~b}$ & $+0,39 \mathrm{~b}$ & $4,32 \mathrm{~b}$ & $+0,06 \mathrm{~b}$ & $4,17 \mathrm{~b}$ & $-0,18 b$ \\
\hline \multirow[t]{4}{*}{ S. aureus } & kont & $4,24 a$ & $+0,55 a$ & $4,38 a$ & $+0,57 a$ & $4,24 a$ & $+0,20 a$ & $4,74 a$ & $+0,11 a^{*}$ \\
\hline & $\mathrm{kf}$ & $3,24 \mathrm{~b}$ & $+1,07 \mathrm{~b}$ & $3,69 \mathrm{~b}$ & $+1,10 \mathrm{a}$ & ND & $+4,12 \mathrm{~b}$ & ND & $+4,14$ \\
\hline & maj & $2,73 \mathrm{c}$ & $+0,19 \mathrm{c}$ & $3,27 \mathrm{c}$ & $+0,08 \mathrm{c}$ & ND & $+3,02 \mathrm{~b}$ & ND & $+3,50 \mathrm{c}$ \\
\hline & fah & $3,60 \mathrm{~d}$ & $+0,46 \mathrm{~d}$ & $4,08 \mathrm{~d}$ & $+0,18 \mathrm{~d}$ & $3,51 \mathrm{c}$ & $+0,63 \mathrm{~b}$ & $3,41 \mathrm{c}$ & $+0,69 \mathrm{~b}$ \\
\hline \multirow[t]{4}{*}{ MRSA } & kont & $3,94 a$ & $+0,42$ & $4,12 a$ & $+0,28 a$ & $3,95 a$ & $+0,39 a$ & $3,63 a$ & $+0,69 a$ \\
\hline & $\mathrm{kf}$ & $3,66 \mathrm{~b}$ & ND & $3,86 \mathrm{~b}$ & $-0,67 \mathrm{~b}$ & ND & ND & ND & ND \\
\hline & maj & $3,03 \mathrm{c}$ & ND & $3,19 \mathrm{c}$ & ND & ND & ND & ND & ND \\
\hline & fah & $2,57 \mathrm{~d}$ & ND & $2,85 \mathrm{~d}$ & ND & $2,52 \mathrm{~b}$ & $+0,97 \mathrm{~b}$ & $2,85 \mathrm{~b}$ & $+0,51 \mathrm{~b}$ \\
\hline \multirow[t]{4}{*}{ L. monocytogenes } & kont & $3,93 a$ & $+0,61 a$ & $4,47 a$ & $+0,49 a^{*}$ & $3,78 a$ & $+0,22 a$ & $3,62 a$ & $+0,19 a \#$ \\
\hline & $\mathrm{kf}$ & $2,90 \mathrm{~b}$ & $+0,40 \mathrm{~b}$ & $3,64 \mathrm{~b}$ & $-0,36 \mathrm{~b}$ & $3,70 \mathrm{a}$ & $-0,42 b$ & $3,54 \mathrm{a}$ & $-0,08 \mathrm{~b}$ \\
\hline & maj & $3,03 \mathrm{c}$ & $+0,79 \mathrm{c}$ & $3,91 \mathrm{c}$ & $-0,41 \mathrm{c}$ & $3,51 \mathrm{~b}$ & $+0,01 \mathrm{c}$ & $3,29 \mathrm{~b}$ & $+0,01 \mathrm{c}$ \\
\hline & fah & $3,91 \mathrm{a}$ & $+0,34 \mathrm{a}$ & $4,40 \mathrm{a}$ & $+0,38 \mathrm{a}$ & $3,61 \mathrm{a}$ & $-0,97 \mathrm{~d}$ & $2,29 \mathrm{c}$ & $+1,11 \mathrm{c}$ \\
\hline \multirow[t]{4}{*}{ B. cereus } & kont & ND & ND & $2,42 a$ & $+0,39 a^{*}$ & $2,10 a$ & $+0,37 a$ & $2,48 a$ & $+0,19 a \#$ \\
\hline & $\mathrm{kf}$ & ND & ND & ND & ND & ND & ND & $2,37 \mathrm{a}$ & $-0,07 \mathrm{~b}$ \\
\hline & maj & ND & ND & ND & ND & ND & ND & ND & ND \\
\hline & fah & ND & ND & ND & ND & ND & ND & ND & ND \\
\hline \multirow[t]{4}{*}{ B. subtilis } & kont & $2,32 a$ & $+0,08 a$ & $2,37 a$ & $0,23 a$ & $2,46 a$ & $0,33 a$ & $2,52 a$ & $+0,32 a$ \\
\hline & $\mathrm{kf}$ & $\mathrm{ND} b$ & $\mathrm{ND} b$ & $\mathrm{ND} b$ & $\mathrm{ND} b$ & $\mathrm{ND} b$ & $\mathrm{ND} b$ & $2,00 \mathrm{a}$ & $+0,43 \mathrm{a}$ \\
\hline & maj & $\mathrm{ND} b$ & $\mathrm{ND} b$ & $\mathrm{ND} b$ & $\mathrm{ND} b$ & $2,22 \mathrm{a}$ & $0,48 \mathrm{a}$ & $2,22 \mathrm{a}$ & $0,26 \mathrm{a}$ \\
\hline & fah & $\mathrm{ND} \mathrm{b}$ & $\mathrm{ND} \mathrm{b}$ & $2,12 \mathrm{a}$ & $0,48 \mathrm{a}$ & $\mathrm{ND} b$ & $\mathrm{ND} b$ & $2,00 \mathrm{a}$ & $+0,22 \mathrm{a}$ \\
\hline
\end{tabular}

ND: nem detektálható feltapadt baktérium a felületen;

A különböző kisbetűk az egy baktériumra vonatkozó kezelések (beleértve a kontrollt is) közötti szignifikáns eltéréseket mutatják $(\mathrm{p}<0,05)$

*: a szignifikáns különbséget mutatja a két felülethez való tapadás között $(\mathrm{p}<0,05)$;

\#: a két élelmiszer maradvánnyal szennyezett (csirkemell lé, paradicsompüré) felülethez való tapadás közti szignifikáns eltérést mutatja $(\mathrm{p}<0,05)$.

Kont: kontroll, kf: kakukkfüolaj, maj: majoránnaolaj, fah: fahéjolaj. 
Kísérleteinkben a három különböző tényező (felület tulajdonságai, a tápanyagillóolaj kapcsolat és a baktérium tapadási képessége) együtt határozta meg az eredményeinket.

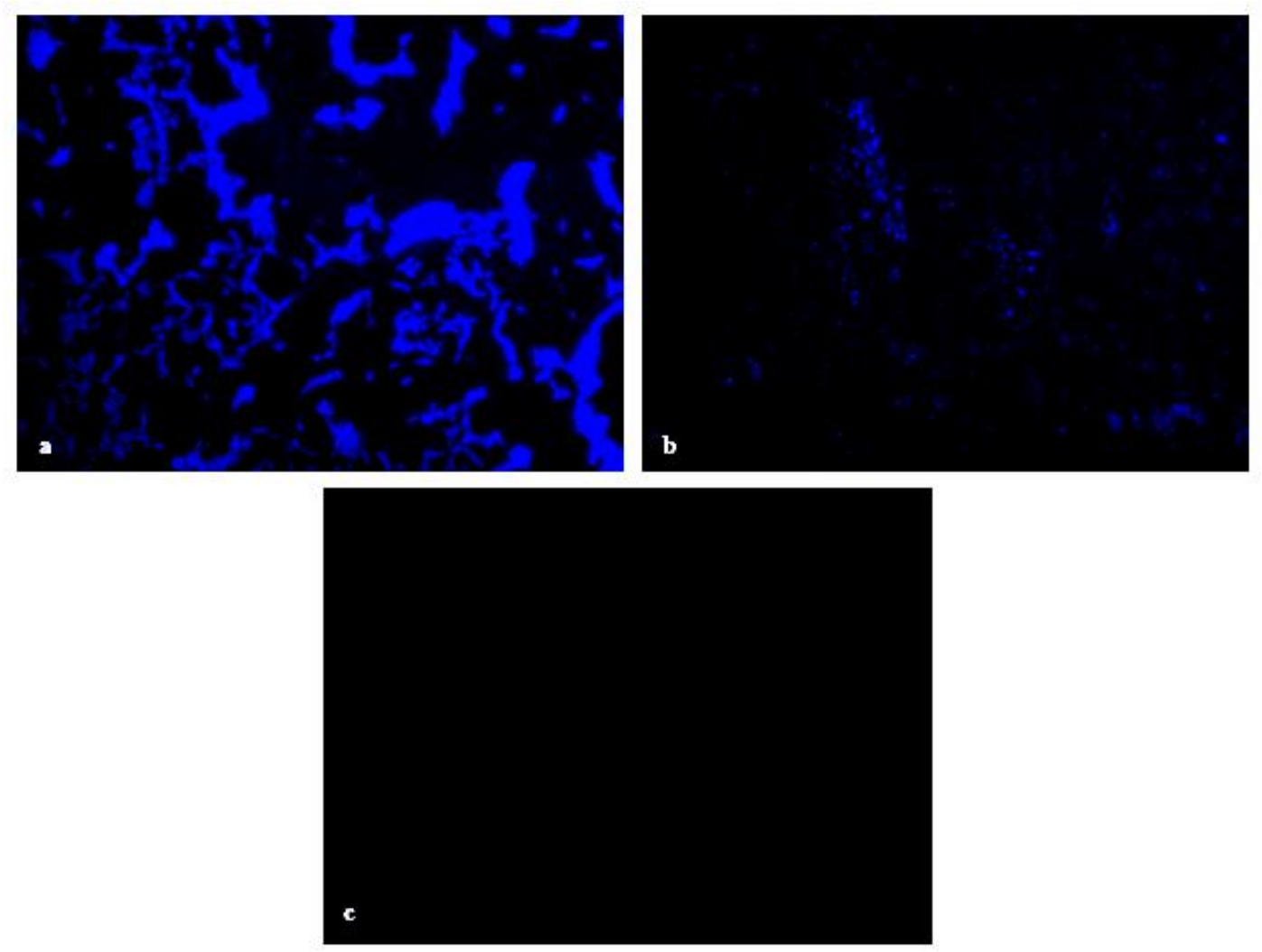

4. ábra. Az MRSA tapadásának vizsgálata DAPI festéssel csirkemell lével kezelt fém felületen (20x nagyítás) a 4. órában (kontroll) (a), a 3. órában (b) és a 4. órában (c) majoránna illóolaj kezelés esetén.

A vegyes tenyészet tapadóképességét szignifikánsan befolyásolta mind a három illóolaj $(\mathrm{p}<0,05)$ (16. táblázat). Ha a populáció egészét nézzük, nem találtunk különbséget a két felülethez való tapadás között $(\mathrm{p}>0,05)$, de a fehérje maradványokat tartalmazó felületen nagyobb számban voltak képesek megtapadni a sejtek $(\mathrm{p}<0,05)$. Ha egyesével néztük az egyes baktériumokat, akkor megállapítható volt, hogy E. coli és $P$. putida sejtek voltak többségben mindkét felületen, de L. monocytogenes sejtek a csirkemelles felületeken nagyobb számban voltak jelen, mint a paradicsompürével kezelten. Az E. coli esetében szignifikáns különbséget nem tapasztaltunk a két felület között. 
16. táblázat. Élelmiszermaradványokat tartalmazó rozsdamentes acél és polipropilén felületen megtapadt kevert tenyészet sejtszáma $\left(\log \mathrm{CFU} / \mathrm{cm}^{2}\right)$ az első óra végén, és a különbség a 4. és az 1. óra végén mért sejtszám között $\left(\Delta, \log \mathrm{CFU} / \mathrm{cm}^{2}\right)$.

\begin{tabular}{lcccccccc}
\hline \multicolumn{9}{c}{ Csirkemell } \\
\hline Felület & \multicolumn{1}{c}{ Rozsdamentes acél } & \multicolumn{2}{c}{ Polipropilén } & \multicolumn{3}{c}{ Rozsdamentes acél } & \multicolumn{2}{c}{ Polipropilén } \\
& 1. óra & $\Delta$ & 1 . óra & $\Delta$ & 1 . óra & $\Delta$ & 1 . óra & $\Delta$ \\
\hline Kontroll & $4,73 \mathrm{a}$ & $0,29 \mathrm{a}$ & $4,70 \mathrm{a}$ & $0,31 \mathrm{a}$ & $4,10 \mathrm{a}$ & $0,83 a$ & $4,12 \mathrm{a}$ & $0,69 \mathrm{a \#}$ \\
Kakukkfüolaj & $3,49 \mathrm{~b}$ & $0,07 \mathrm{~b}$ & $3,74 \mathrm{~b}$ & $0,13 \mathrm{~b}$ & $3,62 \mathrm{~b}$ & $0,36 \mathrm{~b}$ & $3,51 \mathrm{~b}$ & $0,28 \mathrm{~b}$ \\
Majoránnaolaj & $3,91 \mathrm{c}$ & $-0,14 \mathrm{c}$ & $3,83 \mathrm{~b}$ & $-0,03 \mathrm{c}$ & $3,86 \mathrm{c}$ & $-0,29 \mathrm{c}$ & $3,67 \mathrm{~b}$ & $0,20 \mathrm{~b}$ \\
Fahéjolaj & $3,99 \mathrm{c}$ & $-0,11 \mathrm{c}$ & $4,04 \mathrm{c}$ & $-0,40 \mathrm{c}$ & $3,97 \mathrm{c}$ & $-0,48 \mathrm{c}$ & $3,95 \mathrm{a}$ & $-0,57 \mathrm{c}$ \\
\hline
\end{tabular}

A különböző kisbetük az egy baktériumra vonatkozó kezelések (beleértve a kontrollt is) közötti szignifikáns eltéréseket mutatják $(\mathrm{p}<0,05)$;

\#: a két élelmiszer maradvánnyal szennyezett (csirkemell lé, paradicsompüré) felülethez való tapadás közti szignifikáns eltérést mutatja $(\mathrm{p}<0,05)$.

Az ipari üzemekből izolált törzsekkel kapott eredményeket a 17. táblázat tartalmazza. Megállapítottuk, hogy nem volt szignifikáns eltérés $(p>0,05)$ a szénhidrát-rost (paradicsompüré) és fehérje-zsír (csirkemell lé) tartalmú felülethez való tapadás között és a két különböző típusú felülethez való tapadás között sem. A vizsgált izolátumok közül a legellenállóbb az Enterobacter izolátum volt, ahol az illóolajok csak a 3.-4. órában tudták szignifikánsan befolyásolni a tapadást. Megállapítható az eddigi adatok alapján, hogy az Enterobacter izolátum mutatja a legnagyobb rezisztenciát az illóolajokkal szemben (17. táblázat), melyet már a kölcsönhatási vizsgálatok is jól mutattak (11. táblázat). Megállapítottuk, hogy a tápanyagforrás az ipari üzemekből izolált törzsek esetén is csökkentette az illóolajok hatását. A nemzetségen belüli különbségek itt is jól láthatóak, míg a törzsgyüjteményből származó $E$. coli (15. táblázat) szénhidráttartalmú felülethez kötődött jobban és a fahéj befolyásolta legkevésbé a kötődését, addig az ipari üzemből izolált Escherichia törzsnél (17. táblázat) nem tapasztaltunk különbséget a két tápanyag alkalmazásakor. A Pseudomonas izolátumoknál is elmondható, hogy a $P$. putida esetén különbséget tapasztaltunk a fahéjolaj és a majoránnaolaj között, addig az ipari üzemből izolált Pseudomonas törzsnél (15. táblázat) ez nem volt megfigyelhető, azaz itt egységesen hatottak az illóolajok. Összességében elmondhatjuk, hogy a majoránna illóolaj volt a leghatásosabb, néhány kivételtől eltekintve. A Serratia izolátum esetén ugyanis ugyanazt figyeltük meg, mint a $P$. putida-nál, azaz a majoránnaolaj és fahéj illóolaj közül a fahéjolaj tudta a tapadás elleni hatását jobban kifejteni. 
17. táblázat. Élelmiszermaradványokat tartalmazó rozsdamentes acél és polipropilén felületen megtapadt izolátumok sejtszáma $\left(\log C F U / \mathrm{cm}^{2}\right)$ az első óra végén, és a különbség a 4. és az 1. óra végén mért sejtszám között $\left(\Delta, \log C F U / \mathrm{cm}^{2}\right)$.

\begin{tabular}{|c|c|c|c|c|c|c|c|c|c|}
\hline \multirow{3}{*}{ Felület } & & \multicolumn{4}{|c|}{ Csirkemell } & \multicolumn{4}{|c|}{ Paradicsompüré } \\
\hline & & \multicolumn{2}{|c|}{ Rozsdamentes acél } & \multicolumn{2}{|c|}{ Polipropilén } & \multicolumn{2}{|c|}{ Rozsdamentes acél } & \multicolumn{2}{|c|}{ Polipropilén } \\
\hline & & 1. óra & $\Delta$ & 1. óra & $\Delta$ & 1. óra & $\Delta$ & 1. óra & $\Delta$ \\
\hline \multirow[t]{4}{*}{ Citrobacter sp. } & kont & $4,23 a$ & $+0,69 a$ & $4,26 a$ & $+0,84 a$ & $4,11 a$ & $+0,75 a$ & $4,19 a$ & $+0,85 a$ \\
\hline & $\mathrm{kf}$ & $4,00 \mathrm{~b}$ & $+0,70 \mathrm{~b}$ & $3,00 \mathrm{~b}$ & $+1,30 \mathrm{~b}$ & $3,91 \mathrm{~b}$ & $+0,15 \mathrm{~b}$ & $4,02 \mathrm{~b}$ & $+0,34 \mathrm{~b}$ \\
\hline & maj & $3,78 \mathrm{c}$ & $-0,24 c$ & $3,22 \mathrm{~b}$ & $+1,63 \mathrm{c}$ & $2,97 \mathrm{c}$ & $-0,42 c$ & $2,40 \mathrm{c}$ & $+0,42 \mathrm{c}$ \\
\hline & fah & $3,59 \mathrm{c}$ & $-0,11 c$ & $3,83 \mathrm{c}$ & $-0,20 d$ & $3,57 \mathrm{~d}$ & $+0,30 \mathrm{~b}$ & $3,91 \mathrm{~d}$ & $+0,11 \mathrm{~d}$ \\
\hline \multirow[t]{4}{*}{ Escherichia sp. } & kont & $4,03 a$ & $+0,67 a$ & $4,11 a$ & $+0,84 a$ & $4,15 a$ & $+0,48 a$ & $4,34 a$ & $+0,42 a$ \\
\hline & $\mathrm{kf}$ & $3,96 \mathrm{a}$ & $-0,50 \mathrm{~b}$ & $3,98 \mathrm{a}$ & $-0,57 \mathrm{~b}$ & $3,80 \mathrm{~b}$ & $-0,05 \mathrm{~b}$ & $3,42 \mathrm{~b}$ & $+0,23 \mathrm{~b}$ \\
\hline & maj & $3,24 \mathrm{~b}$ & $+1,18 \mathrm{~b}$ & $3,22 \mathrm{~b}$ & $+0,98 \mathrm{c}$ & $3,40 \mathrm{c}$ & $+0,87 \mathrm{c}$ & $3,34 \mathrm{~b}$ & $+0,79 \mathrm{c}$ \\
\hline & fah & $3,82 \mathrm{c}$ & $+0,88 \mathrm{a}$ & $3,76 \mathrm{c}$ & $+1,18 \mathrm{a}$ & $4,07 \mathrm{a}$ & $+0,56 \mathrm{a}$ & $3,94 \mathrm{c}$ & $+0,82 \mathrm{a}$ \\
\hline \multirow[t]{4}{*}{ Enterobacter sp. } & kont & $4,51 a$ & $+0,29 a$ & $4,43 a$ & $+0,31 a$ & $4,42 a$ & $+0,25 a$ & $4,44 a$ & $+0,28 a$ \\
\hline & $\mathrm{kf}$ & $4,31 \mathrm{a}$ & $+0,24 \mathrm{~b}$ & $4,31 \mathrm{a}$ & $+0,37 \mathrm{~b}$ & $4,19 \mathrm{~b}$ & $+0,31 \mathrm{~b}$ & $4,37 \mathrm{a}$ & $+0,48 \mathrm{~b}$ \\
\hline & maj & $4,39 \mathrm{a}$ & $-0,15 \mathrm{c}$ & $4,33 \mathrm{a}$ & $-0,13 \mathrm{c}$ & $4,36 \mathrm{a}$ & $-0,18 \mathrm{c}$ & $4,40 \mathrm{a}$ & $-0,16 \mathrm{c}$ \\
\hline & fah & $4,36 \mathrm{a}$ & $+0,21 \mathrm{~b}$ & $4,38 \mathrm{a}$ & $+0,35 \mathrm{~b}$ & $4,37 \mathrm{a}$ & $+0,45 \mathrm{~b}$ & $4,39 \mathrm{a}$ & $+0,47 \mathrm{~b}$ \\
\hline \multirow[t]{4}{*}{ Pseudomonas sp. } & kont & $4,29 a$ & $+0,49 a$ & $4,45 a$ & $+0,41 a$ & $4,15 a$ & $+0,63 a$ & $4,14 a$ & $+0,76 a$ \\
\hline & $\mathrm{kf}$ & $3,43 \mathrm{~b}$ & $+0,36 \mathrm{~b}$ & $3,66 \mathrm{~b}$ & $+0,18 \mathrm{~b}$ & $3,29 \mathrm{~b}$ & $+0,51 \mathrm{~b}$ & $3,43 \mathrm{~b}$ & $+0,38 \mathrm{~b}$ \\
\hline & maj & $3,12 \mathrm{c}$ & $+0,65 \mathrm{~b}$ & $3,61 \mathrm{~b}$ & $+0,17 \mathrm{~b}$ & $3,07 \mathrm{c}$ & $+0,64 \mathrm{~b}$ & $3,22 \mathrm{~b}$ & $+0,53 \mathrm{~b}$ \\
\hline & fah & $3,25 \mathrm{c}$ & $+0,62 \mathrm{~b}$ & $3,77 \mathrm{~b}$ & $+0,12 \mathrm{~b}$ & $3,24 \mathrm{~b}$ & $+0,73 \mathrm{~b}$ & $3,63 \mathrm{c}$ & $+0,43 \mathrm{c}$ \\
\hline \multirow[t]{3}{*}{ Serratia sp. } & kont & $4,59 a$ & $+0,06 a$ & $4,55 a$ & $+0,08 a$ & $4,53 a$ & $+0,12 a$ & $4,47 a$ & $+0,18 a$ \\
\hline & maj & $3,97 \mathrm{~b}$ & $+0,27 \mathrm{~b}$ & $4,13 b$ & $+0,16 \mathrm{~b}$ & $3,84 \mathrm{~b}$ & $+0,30 \mathrm{~b}$ & $4,05 \mathrm{~b}$ & $+0,18 \mathrm{~b}$ \\
\hline & fah & $3,41 \mathrm{c}$ & $+0,10 \mathrm{c}$ & $3,79 \mathrm{c}$ & $+0,20 \mathrm{c}$ & $2,25 \mathrm{c}$ & $+1,62 \mathrm{c}$ & $2,97 \mathrm{c}$ & $+0,17 \mathrm{c}$ \\
\hline
\end{tabular}

A különböző kisbetük az egy baktériumra vonatkozó kezelések (beleértve a kontrollt is) közötti szignifikáns eltéréseket mutatják; $(\mathrm{p}<0,05)$. Kont: kontroll, kf: kakukkfüolaj, maj: majoránnaolaj, fah: fahéjolaj.

Az élelmiszermaradványt tartalmazó környezetben a fehérje és a zsír megkötheti az illóolajokat és befolyásolhatja a baktériumok kötődését. Ha a felületről eltávolítjuk a fehérjét, az illóolaj hatása javulhat. A fahéj illóolaj fő komponense, a fahéjaldehid képes kovalensen kötődni a fehérjékhez. A fahéjolaj a L. monocytogenes (15. táblázat) esetén nem hatott szignifikánsan ( $\mathrm{p}>0,05)$, föleg a nagyobb fehérje tápanyagforrású felületen. A fehérjék eltávolítása után javult a fahéjolaj tapadást befolyásoló hatása. Hyldgaard és munkatársai (2012), majd Nazzaro és munkatársai (2013) is azt a megállapítást tették, hogy a fahéjaldehid képes gátolni az enzimeket és ezáltal mintegy ATP gátlóként is müködik. A 6.5. fejezet eredményei alapján megállapíthatjuk, hogy a fahéj illóolaj jobban befolyásolta a tapadást paradicsompürével kezelt felületen, mint a csirkemell lével kezelten. Ez a különbség abból adódhat, hogy a két szennyezés különböző fehérjéket tartalmaz. A 
csirkemell esetén vízben oldható szarkoplazmatikus fehérjék lehettek a felületen (Bowker és Zhuang, 2013), melyeknek nagy az illékony komponens megkötő képessége (kovalens vagy hidrogénkötéssel). Ezzel szemben a növényi fehérjék esetén nincs szulfhidril csoport és az aldehidekkel való reakció limitált (Krisch és mtsi., 2012).

A 6.4. és az 6.5. fejezet alapján az illóolajok hatását negatívan befolyásolja, ha van a felületen valamilyen élelmiszermaradvány. A felület, illóolaj, tápanyagforrás és baktérium közötti kölcsönhatások értékelése további vizsgálatok célpontja lehet, mivel az irodalomban e tényezők együttes hatását még nem vizsgálták. Az irodalomban a legtöbb megállapítás az illóolaj-baktérium-élelmiszer hármasára vonatkozott, ahol az illóolaj tartósítószerként volt jelen. A fehérjék, rostok, zsírok, összetett szénhidrátok képesek csökkenteni az illóolajok hatását, míg a só és az egyszerü szénhidrátok növelhetik (Ahn és mtsi., 2007; Busatta és mtsi., 2008; Cava és mtsi., 2007; Gutierrez és mtsi., 2008, 2009; Hyldgaard és mtsi., 2012; Juven és mtsi., 1994; Nazzaro és mtsi., 2013; Periccone és mtsi., 2015; Shelef és mtsi., 1984; Singh és mtsi., 2003).

Az illóolajok pontos hatásmechanizmusának leírása nehezen kivitelezhető, mert az összetételük és kémiai tulajdonságuk miatt a baktériumokon másképpen hatnak. A baktériumok különböző tapadási képessége miatt is eltérő a hatásuk, más mechanizmust tudnak befolyásolni. Mindenesetre eredményeink alapján elmondhatjuk, hogy az illóolajok felületi fertőtlenítőként való használata előtt a szerves szennyeződéseket el kell távolítani az alkalmazni kívánt felületről, mely ipari környezetben megfelel a szokásos tisztításifertőtlenítési eljárásnak.

\subsection{Tapadás vizsgálat eredményei illóolajjal bevont felületen}

Ezen kísérleti résznél a felületek illóolaj réteget tartalmaztak és a közeg (baktériumszuszpenzió) illóolajmentes volt. Ebben az esetben is szignifikáns kitapadás csökkenést $(\mathrm{p}<0,05)$ kaptunk a kontroll felületekhez képest (illóolajmentes felületek), a különbség mértéke 1-2 log CFU/ml nagyságrendű volt. A legtöbb esetben a rozsdamentes acél felületen volt itt is kisebb mértékü a sejtmegtapadás. $P$. putida tapadásánál nem volt szignifikáns különbség a kezelt és kezeletlen lapokhoz való kötődés között ( $p>0,05)$. Ezen vonalon haladva polimer réteget lehetne alkalmazni a felületeken, mely illóolajat vagy azok komponenseit tartalmazza. 


\subsection{Illóolajok hatásának kinetikai vizsgálata az idő, koncentráció és pH alapján}

A vizsgálatok célja a minél rövidebb, lehetőleg 30 percnél kisebb hatóidő alatt teljes pusztulást okozó illóolaj koncentráció és pH megtalálása volt. Ezek a kísérletek egyben elökísérletekként szolgáltak a biofilm eliminálási vizsgálatokhoz. Az első kísérlet során az illóolajok korábban meghatározott MBC értékeinek megfelelő koncentrációkat alkalmaztuk. A három illóolaj közül csak a majoránnaolaj volt képes egyszeres MBC koncentrációnál a $P$. putida pusztulását okozni 10 perc alatt, míg a többi törzsgyüjteményből származó baktériumnál ehhez 30 percnél több idő kellett (18. táblázat). Az irodalomban kevés adatot találtunk arról, hogy az illóolajok milyen gyorsan képesek elpusztítani a baktériumokat. Tisserand (2014) könyvében a Staphylococcus fajok pusztulási ideje kakukkfü illóolajjal történő kezelés esetén 150 perc volt.

Az előzetes kísérletek után az MBC értékek két- háromszorosát alkalmaztuk. A koncentráció növelésével már csökkenteni tudtuk a pusztulási időt, de ehhez a legtöbb esetben még 30 perc vagy annál is több idő kellett a legnagyobb alkalmazott koncentráció esetében is (18. táblázat). A fahéjolaj rendelkezett a legalacsonyabb MBC értékkel, de rövid távú hatása alul maradt a többi illóolajjal szemben, mivel az $E$. coli, a $L$. monocytogenes, a $S$. aureus és az MRSA izolátum esetén sem kaptunk 30 perc alatti vagy azzal egyenlő pusztulási időket (30 perces hatóidő még elfogadható ipari felhasználásra). A két Bacillus faj közül a B. subtilis volt érzékenyebb az illóolajokra. Az izolátumok sokkal érzékenyebben reagáltak a fahéj illóolajra, koncentrációtól függetlenül akár 5 perc alatt elpusztultak (18. táblázat). A 30 perc feletti értékek még túl hosszúak egy fertőtlenítés során, ezért a koncentráció emelése mellett a további pusztulási idő csökkentés érdekében a savas és lúgos kémhatást is alkalmaztuk. Emellett a további kinetikai kísérletek során a vizsgált hatóidő intervallumát is lecsökkentettük 30 percre a későbbi ipari alkalmazhatóság érdekében. 
18. táblázat. A baktériumok pusztulási ideje (perc) az illóolaj koncentráció függvényében.

\begin{tabular}{|c|c|c|c|c|c|c|}
\hline \multirow{2}{*}{$\begin{array}{l}\text { Illóolaj } \\
\text { Baktérium }\end{array}$} & \multicolumn{2}{|c|}{ Kakukkfü } & \multicolumn{2}{|c|}{ Majoránna } & \multicolumn{2}{|c|}{ Fahéj } \\
\hline & $\begin{array}{c}\text { Koncentráció } \\
{[\mathrm{mg} / \mathrm{ml}]}\end{array}$ & $\begin{array}{l}\text { Pusztulási } \\
\text { idő (perc) }\end{array}$ & $\begin{array}{c}\text { Koncentráció } \\
{[\mathrm{mg} / \mathrm{ml}]}\end{array}$ & $\begin{array}{l}\text { Pusztulási } \\
\text { idő (perc) }\end{array}$ & $\begin{array}{c}\text { Koncentráció } \\
{[\mathrm{mg} / \mathrm{ml}]}\end{array}$ & $\begin{array}{l}\text { Pusztulási } \\
\text { idő (perc) }\end{array}$ \\
\hline \multirow[t]{3}{*}{ E. coli } & 1,6 & $>120$ & 1,6 & $>120$ & 0,2 & $>120$ \\
\hline & 3,2 & 60 & 3,2 & $>120$ & 0,4 & $>120$ \\
\hline & 4,8 & 25 & 4,8 & 25 & 0,6 & 90 \\
\hline \multirow[t]{3}{*}{ P. putida } & NA & NA & 6,3 & 10 & 0,8 & 120 \\
\hline & NA & NA & 12,6 & 10 & 1,6 & 60 \\
\hline & NA & NA & 18,9 & 5 & 2,4 & 25 \\
\hline \multirow[t]{3}{*}{ S. aureus } & 1,6 & $>120$ & 6,3 & $>120$ & 0,8 & $>120$ \\
\hline & 3,2 & 90 & 12,6 & 30 & 1,6 & 60 \\
\hline & 4,8 & 60 & 18,9 & 25 & 2,4 & 90 \\
\hline \multirow[t]{4}{*}{ MRSA } & 12,5 & $>120$ & 6,3 & $>120$ & 3,2 & $>120$ \\
\hline & 25 & 30 & 12,6 & 60 & 6,4 & $>120$ \\
\hline & 37,5 & 30 & 18,9 & 30 & 9,6 & 90 \\
\hline & 6,3 & $>120$ & 6,3 & $>120$ & 1,6 & $>120$ \\
\hline \multirow[t]{2}{*}{ L. monocytogenes } & 12,6 & 10 & 12,6 & 30 & 3,2 & $>120$ \\
\hline & 18,9 & 10 & 18,9 & 20 & 4,8 & $>120$ \\
\hline \multirow[t]{3}{*}{ B. cereus } & 3,2 & 30 & 3,2 & 30 & 0,8 & $>120$ \\
\hline & 6,4 & 30 & 6,4 & 30 & 1,6 & 90 \\
\hline & 9,6 & 25 & 9,6 & 25 & 2,4 & 60 \\
\hline \multirow[t]{3}{*}{ B. subtilis } & 1,6 & $>120$ & 3,2 & $>120$ & 0,4 & $>120$ \\
\hline & 3,2 & 10 & 6,4 & 5 & 0,8 & 60 \\
\hline & 4,8 & 10 & 9,6 & 5 & 1,2 & 15 \\
\hline \multirow[t]{3}{*}{ Vegyes tenyészet } & 12,5 & 10 & 12,5 & 90 & 1,6 & 90 \\
\hline & 25 & 10 & 25 & 60 & 3,2 & 60 \\
\hline & 37,5 & 5 & 37,5 & 25 & 3,8 & 25 \\
\hline \multirow[t]{3}{*}{ Citrobacter sp. } & 3,2 & 10 & 12,5 & 10 & 1,6 & 30 \\
\hline & 6,4 & 5 & 25 & 5 & 3,2 & 5 \\
\hline & 9,6 & 5 & 37,5 & 5 & 4,8 & 5 \\
\hline \multirow[t]{3}{*}{ Serratia sp. } & NA & NA & 50 & 90 & 3,2 & 5 \\
\hline & NA & NA & 100 & 60 & 6,4 & 5 \\
\hline & NA & NA & 150 & 25 & 9,6 & 5 \\
\hline \multirow[t]{3}{*}{ Enterobacter sp. } & 1,6 & 10 & 25 & 30 & 3,2 & 5 \\
\hline & 3,2 & 5 & 50 & 30 & 6,4 & 5 \\
\hline & 4,8 & 5 & 75 & 10 & 9,6 & 5 \\
\hline \multirow[t]{3}{*}{ Escherichia sp. } & 6,3 & 10 & 50 & 90 & 3,2 & 5 \\
\hline & 12,6 & 10 & 100 & 60 & 6,4 & 5 \\
\hline & 18,9 & 5 & 150 & 30 & 9,6 & 5 \\
\hline \multirow[t]{3}{*}{ Pseudomonas sp. } & 3,2 & 10 & 50 & 30 & 6,3 & 5 \\
\hline & 6,3 & 10 & 100 & 30 & 12,6 & 5 \\
\hline & 9,5 & 5 & 150 & 25 & 18,9 & 5 \\
\hline
\end{tabular}

NA nincs MBC adat $25 \mathrm{mg} / \mathrm{ml}$ koncentráció alatt 
Az illóolajos oldat kémhatásának változtatása során lúgos $\mathrm{pH}$ esetén kaptunk már egyszeres MBC alkalmazásánál is olyan pusztulási időket, melyeket a későbbiekben a biofilm eliminálási vizsgálatokban fel tudtunk használni a fertőtlenítési idő meghatározására. A törzsgyüjteményből származó baktériumokra főleg a lúgos kémhatású illóolajos közeg hatott jól, míg az ipari üzemböl izolált törzsek főleg a savas kémhatású illóolajokra voltak érzékenyek. Nostro és munkatársai (2012) megállapították, hogy a savas környezet elősegíti az illóolajok hatását, mivel még inkább hidrofóbbá teszi őket, ezáltal könnyebben lépnek kölcsönhatásba a sejtfallal. A pH eltolás hatására a hatóidő általában 525 percre csökkent. Az illóolaj koncentrációjának emelésével, és a fertőtlenítőoldat lúgosításával a kakukkfü illóolaj baktericid képességét javítottuk a legnagyobb mértékben (19.-20. táblázat).

A pH változtatásával a fahéj illóolaj hatóidejét csak kis mértékben tudtuk javítani, szinte csak a B. subtilis és a P. putida esetén. Sutherland és munkatársai (1996) megállapították, hogy a vizsgált $B$. cereus izolátum esetében az antimikrobiális szer még pH 4,0 esetén sem eredményezett jobb hatóidőt, mivel a $B$. cereus izolátum még 4,35-ös pH-n is tudott szaporodni. Kísérletünkben a két Staphylococcus aureus szinte hasonlóan reagált a fahéj illóolajra (19. táblázat). Az eddigi eredmények alapján e tekintetben nincs egyértelmü különbség a Gram-negatív és Gram-pozitív baktériumok között. Azonban mindenféleképpen számolnunk kell a baktériumok egyéni érzékenységével.

Vegyes populáció esetében a kakukkfü illóolaj hatóideje 10 perc volt. A 8,5-ös pHjú illóolaj oldat kevésbé volt hatásos a vegyes tenyészeten, mint az azt alkotó baktériumokon külön-külön. Jól látható a 19. táblázatban, hogy a savas környezet jobban elősegítette a vegyes populáció pusztulását. Mint minden vegyes tenyészettel való kísérlet során, itt is megvizsgáltuk a populáció összetételét az idő változása során. Összeségben elmondható, hogy a Gram-negatív baktériumok túlnőtték a Gram-pozitív baktériumokat: $P$. putida $>$ E. coli $>$ L. monocytogenes $>$ S. aureus, az eltérés egy log CFU/ml alatt maradt. $\mathrm{Az}$ ipari üzemből izolált törzsek lúgos $\mathrm{pH}$-val szembeni érzéketlensége hátterében az adaptáció állhat. A mintavétel helyéül szolgáló üzemekben főként lúgos tisztítószert használnak, így a baktériumok alkalmazkodhattak már a lúgos környezethez. 
19. táblázat. A baktériumok pusztulási ideje (perc) az illóolaj koncentráció és a pH változatás együttes hatására.

\begin{tabular}{|c|c|c|c|c|c|c|c|c|c|}
\hline \multirow{3}{*}{$\begin{array}{l}\text { Illóolaj } \\
\text { Baktérium }\end{array}$} & \multicolumn{3}{|c|}{ Kakukkfü } & \multicolumn{3}{|c|}{ Majoránna } & \multicolumn{3}{|c|}{ Fahéj } \\
\hline & \multirow{2}{*}{$\begin{array}{l}\text { Konc. } \\
{[\mathrm{mg} / \mathrm{ml}]}\end{array}$} & \multicolumn{2}{|c|}{$\begin{array}{l}\text { Pusztulási idő } \\
\text { (perc) }\end{array}$} & \multirow{2}{*}{$\begin{array}{c}\text { Konc. } \\
{[\mathrm{mg} / \mathrm{ml}]}\end{array}$} & \multicolumn{2}{|c|}{$\begin{array}{l}\text { Pusztulási idő } \\
\text { (perc) }\end{array}$} & \multirow{2}{*}{$\begin{array}{l}\text { Konc. } \\
{[\mathrm{mg} / \mathrm{ml}]}\end{array}$} & \multicolumn{2}{|c|}{$\begin{array}{l}\text { Pusztulási idő } \\
\text { (perc) }\end{array}$} \\
\hline & & $4,5 \mathrm{pH}$ & $8,5 \mathrm{pH}$ & & $4,5 \mathrm{pH}$ & $8,5 \mathrm{pH}$ & & $4,5 \mathrm{pH}$ & $8,5 \mathrm{pH}$ \\
\hline \multirow[t]{2}{*}{ E. coli } & 1,6 & $>30$ & 5 & 1,6 & $>30$ & 5 & 0,2 & $>30$ & $>30$ \\
\hline & 3,2 & 10 & 5 & 3,2 & $>30$ & 5 & 0,4 & $>30$ & $>30$ \\
\hline \multirow[t]{2}{*}{ P. putida } & NA & NA & NA & 6,3 & 10 & 5 & 0,8 & $>30$ & 15 \\
\hline & NA & NA & NA & 12,6 & 10 & 5 & 1,6 & 15 & 10 \\
\hline \multirow[t]{2}{*}{ S. aureus } & 1,6 & $>30$ & $>30$ & 6,3 & $>30$ & $>30$ & 0,8 & $>30$ & $>30$ \\
\hline & 3,2 & 25 & 10 & 12,6 & 15 & 10 & 1,6 & $>30$ & 5 \\
\hline \multirow[t]{2}{*}{ MRSA } & 12,5 & $>30$ & 5 & 6,3 & $>30$ & $>30$ & 3,2 & $>30$ & $>30$ \\
\hline & 25 & 15 & 5 & 12,6 & 30 & 5 & 6,4 & $>30$ & 5 \\
\hline \multirow[t]{2}{*}{ L. monocytogenes } & 6,3 & $>30$ & 5 & 6,3 & $>30$ & 5 & 1,6 & $>30$ & $>30$ \\
\hline & 12,6 & 5 & 5 & 12,6 & 5 & 5 & 3,2 & $>30$ & $>30$ \\
\hline \multirow[t]{2}{*}{ B. cereus } & 3,2 & 15 & 5 & 3,2 & 30 & 25 & 0,8 & $>30$ & 25 \\
\hline & 6,4 & 15 & 5 & 6,4 & 30 & 25 & 1,6 & $>30$ & 20 \\
\hline \multirow[t]{2}{*}{ B. subtilis } & 1,6 & 30 & 5 & 3,2 & $>30$ & 10 & 0,4 & $>30$ & 15 \\
\hline & 3,2 & 10 & 5 & 6,4 & 5 & 10 & 0,8 & 15 & 10 \\
\hline \multirow[t]{2}{*}{ Vegyes tenyészet } & 12,5 & 10 & 10 & 12,5 & 10 & 15 & 1,6 & 15 & $>30$ \\
\hline & 25 & 10 & 10 & 25 & 10 & 15 & 3,2 & 15 & $>30$ \\
\hline \multirow[t]{2}{*}{ Citrobacter sp. } & 3,2 & 10 & $>30$ & 12,5 & 10 & $>30$ & 1,6 & 10 & $>30$ \\
\hline & 6,4 & 10 & $>30$ & 25 & 10 & $>30$ & 3,2 & 10 & $>30$ \\
\hline \multirow[t]{2}{*}{ Serratia sp. } & NA & NA & NA & 50 & 5 & $>30$ & 3,2 & 5 & $>30$ \\
\hline & NA & NA & NA & 100 & 5 & $>30$ & 6,4 & 5 & $>30$ \\
\hline \multirow[t]{2}{*}{ Enterobacter sp. } & 1,6 & 10 & $>30$ & 25 & 10 & $>30$ & 3,2 & 5 & $>30$ \\
\hline & 3,2 & 10 & $>30$ & 50 & 10 & $>30$ & 6,4 & 5 & $>30$ \\
\hline \multirow[t]{2}{*}{ Escherichia sp. } & 6,3 & 10 & $>30$ & 50 & 10 & $>30$ & 3,2 & 5 & $>30$ \\
\hline & 12,6 & 10 & $>30$ & 100 & 10 & $>30$ & 6,4 & 5 & $>30$ \\
\hline \multirow[t]{2}{*}{ Pseudomonas sp. } & 3,2 & 10 & $>30$ & 50 & 10 & $>30$ & 6,3 & 5 & $>30$ \\
\hline & 6,3 & 10 & $>30$ & 100 & 10 & $>30$ & 12,6 & 5 & $>30$ \\
\hline
\end{tabular}

NA - nincs MBC adat $25 \mathrm{mg} / \mathrm{ml}$ koncentráció alatt, eért nem néztük a pusztulási kinetikát

Az ipari izolátumok és a törzsgyüjteményből származó fajok összehasonlítása alapján megállapítható, hogy az izolátumok hamarabb pusztulnak el savas és semleges kémhatású illóolajos fertőtlenítőoldatban. Összességében megállapítható, hogy a kakukkfü eredményezte a legrövidebb hatóidőket. A hatóidő általában csökkent a koncentráció növekedésével is, de ez egyben a fertőtlenítés költségének növekedését is maga után vonja. A pH eltolásával azonban, a hatás megőrzése mellett, a koncentráció csökkenthető. A 20. táblázat tartalmazza az előző kísérletek alapján megállapított optimális paramétereket, melyeket a biofilmek eliminálási kísérleteiben alkalmazunk. 
20. táblázat. A biofilm eliminálás során alkalmazott paraméterek: fertőtlenítési idő (perc) koncentráció (mg/ml) és pH értékek.

\begin{tabular}{|c|c|c|c|c|c|c|c|c|c|}
\hline \multirow{2}{*}{$\frac{\text { Illóolaj }}{\text { Baktérium }}$} & \multicolumn{3}{|c|}{ Kakukkfü } & \multicolumn{3}{|c|}{ Majoránna } & \multicolumn{3}{|c|}{ Fahéj } \\
\hline & $\mathrm{cc}$ & $\mathrm{pH}$ & idő & $\mathrm{cc}$ & $\mathrm{pH}$ & idő & $\mathrm{cc}$ & $\mathrm{pH}$ & idő \\
\hline \multirow[t]{3}{*}{ E. coli } & 4,8 & 6,0 & 50 & 4,8 & 6,0 & 50 & & & \\
\hline & 1,6 & 8,5 & 10 & 1,6 & 8,5 & 10 & & & \\
\hline & 3,2 & 4,5 & 10 & & & & & & \\
\hline \multirow[t]{3}{*}{ P.putida } & & & & 6,3 & 6,0 & 20 & 2,4 & 6,0 & 50 \\
\hline & & & & 6,3 & 8,5 & 10 & 0,8 & 8,5 & 30 \\
\hline & & & & 6,3 & 4,5 & 10 & 1,6 & 4,5 & 30 \\
\hline \multirow[t]{3}{*}{ B. cereus } & 6,4 & 6,0 & 50 & 3,2 & 6,0 & 60 & 0,4 & 8,5 & 40 \\
\hline & 3,2 & 8,5 & 10 & 3,2 & 8,5 & 50 & & & \\
\hline & 3,2 & 4,5 & 60 & 3,2 & 4,5 & 60 & & & \\
\hline \multirow[t]{3}{*}{ B. subtilis } & 3,2 & 6,0 & 10 & 6,4 & 6,0 & 10 & 1,2 & 6,0 & 30 \\
\hline & 1,6 & 8,5 & 10 & 3,2 & 8,5 & 10 & 0,4 & 8,5 & 10 \\
\hline & 3,2 & 4,5 & 20 & 6,4 & 4,5 & 10 & 0,8 & 4,5 & 30 \\
\hline \multirow[t]{3}{*}{ L. monocytogenes } & 12,6 & 6,0 & 20 & 18,9 & 6,0 & 40 & & & \\
\hline & 6,3 & 8,5 & 10 & 6,3 & 8,5 & 10 & & & \\
\hline & 12,6 & 4,5 & 10 & 6,3 & 4,5 & 10 & & & \\
\hline \multirow[t]{3}{*}{ MSSA } & 3,2 & 8,5 & 10 & 12,6 & 6,0 & 60 & 1,6 & 8,5 & 10 \\
\hline & & & & 12,6 & 8,5 & 20 & & & \\
\hline & & & & 12,6 & 4,5 & 30 & & & \\
\hline \multirow[t]{3}{*}{ MRSA } & 25,0 & 6,0 & 60 & 12,6 & 6,0 & 60 & 6,3 & 8,5 & 10 \\
\hline & 12,5 & 8,5 & 10 & 12,6 & 8,5 & 10 & & & \\
\hline & 25,0 & 4,5 & 30 & & & & & & \\
\hline \multirow[t]{3}{*}{ Vegyes populáció } & 12,5 & 6,0 & 20 & 25,0 & 6,0 & 50 & 4,8 & 6,0 & 20 \\
\hline & 12,5 & 8,5 & 10 & 12,5 & 8,5 & 30 & 1,6 & 4,5 & 30 \\
\hline & 12,5 & 4,5 & 20 & 12,5 & 4,5 & 20 & & & \\
\hline \multirow[t]{2}{*}{ Citrobacter sp. } & 6,4 & 6,0 & 20 & 12,5 & 6,0 & 50 & 3,2 & 6,0 & 10 \\
\hline & 3,2 & 4,5 & 20 & 12,5 & 4,5 & 20 & 1,6 & 4,5 & 20 \\
\hline \multirow[t]{2}{*}{ Serratia sp. } & & & & 50 & 6,0 & 50 & 3,2 & 6,0 & 10 \\
\hline & & & & 50 & 4,5 & 20 & 3,2 & 4,5 & 20 \\
\hline \multirow[t]{2}{*}{ Enterobacter sp. } & 1,6 & 6,0 & 20 & 25,0 & 6,0 & 25 & 3,2 & 6,0 & 10 \\
\hline & 1,6 & 4,5 & 20 & 25,0 & 4,5 & 20 & 3,2 & 4,5 & 10 \\
\hline \multirow[t]{2}{*}{ Escherichia sp. } & 6,3 & 6,0 & 20 & 100 & 6,0 & 20 & 3,2 & 6,0 & 10 \\
\hline & 6,3 & 4,5 & 20 & 50,0 & 4,5 & 20 & 3,2 & 4,5 & 10 \\
\hline \multirow[t]{2}{*}{ Pseudomonas sp. } & 3,2 & 6,0 & 20 & 100 & 6,0 & 20 & 6,3 & 6,0 & 20 \\
\hline & 3,2 & 4,5 & 20 & 50,0 & 4,5 & 20 & 6,3 & 4,5 & 10 \\
\hline
\end{tabular}

cc: koncentráció;

ahol nincs adat, azon esetekben nem kaptunk alkalmazható fertőtlenítési paramétereket

\subsection{Biofilmek eliminálása illóolajokkal}

Az előző kísérletekben megállapított fertőtlenítési paraméterek alapján (20. táblázat) elimináltuk a kialakult 24 és 168 órás biofilmeket a felületekről. Az illóolajokkal történő felületi fertőtlenítés eredményei ígéretesek, az illóolajos fertőtlenítőszerek képesek 
voltak a felületekről eltávolítani a biofilmeket, vagy szignifikánsan csökkentették $(\mathrm{p}<0,05)$ a biofilm élősejtszámát (21.-22. táblázat). Felületek fertőtlenítésével kapcsolatban kevés irodalmi adatot találtunk, a legtöbb kísérlet szabad sejteken történt (Simões és mtsi., 2010).

Kísérletünk során a 24 órás biofilmben általában több sejt volt, mint a 168 órás mátrixban (21.-22. táblázat). Kusumaningrum és munkatársai (2003) kísérleteik során szintén azt tapasztalták, hogy 100 óra után a sejtszám lecsökkent akár 2 nagyságrenddel is S. aureus esetén. A sejtszámcsökkenést valószínüleg a legbelső rétegben található, anaerob és táplálékszegény viszonyok közé került sejtek pusztulása okozhatta.

A két felületen történő biofilmképzés között nem találtunk szignifikáns különbséget (p>0,05). A leggyengébb biofilmképzők a Bacillus fajok voltak (biofilm sejtszáma $<\log 3$ $\mathrm{CFU} / \mathrm{cm}^{2}$ ). A B. subtilis esetén 24 óra alatt nem is tudott biofilm kialakulni a felületen.

A törzsgyüjteményböl származó baktériumok esetén a savas kémhatású közegben az illóolajok jobb fertőtlenítő tulajdonsággal rendelkeztek. Nostro és munkatársai (2012) munkássága alapján a karvakrol (fenolos típusú komponens) szintén jobb hatású volt savas közegben. A leggyengébb hatással a lúgos fertőtlenítőszerek bírtak, kivéve a $B$. cereus esetében (21. táblázat). A 6.7. fejezetben megállapított eredmények ezzel ellentétesek, mivel ott a lúgos kémhatás esetén javult az illóolajok hatása. A jelenség magyarázatára egyetlen szakirodalmi adatot találtunk; Stewart és munkatársai szerint (2015) a Staphylococcus epidermitis-esetében az EPS réteg stabilitása $\mathrm{pH}$ 8,0 felett növekedett. Nem kizárt, hogy a mi esetünkben is hasonló változások következtek be, de a jelenség magyarázata további kutatásokat kíván.

Az L. monocytogenes biofilmen a lúgos fertőtlenítőszer kivételével minden kezelés 100\%-osan hatott. Desai és munkatársai (2012) közleményében a L. monocytogenes sejtek által képzett biofilmet nem tudták eltüntetni 4 órás kakukkfüolajos kezelés után $(\sim 4,5$ $\mathrm{mg} / \mathrm{ml}$ ), azonban 24 órás kezelés után már igen. Az általunk alkalmazott fertőtlenítés ezzel szemben kivitelezhetőnek tünik (10 perc; 12,6 mg/ml; pH 4,5). Soni és munkatársai (2013) kísérletében is szükséges volt a hatóidő emelése Salmonella sejtekből képzett biofilm esetén. 
21. táblázat. Biofilm eliminálás eredményei: túlélő baktériumszám $\left(\log \mathrm{CFU} / \mathrm{cm}^{2}\right)$ a törzsgyüjteményből származó baktériumok esetén.

\begin{tabular}{|c|c|c|c|c|c|c|c|c|c|c|}
\hline \multirow{3}{*}{\multicolumn{3}{|c|}{$\begin{array}{l}\text { Felületek } \\
\text { Biofilm kora (óra) }\end{array}$}} & \multicolumn{4}{|c|}{ Rozsdamentes acél } & \multicolumn{4}{|c|}{ Polipropilén } \\
\hline & & & \multicolumn{2}{|c|}{24} & \multicolumn{2}{|c|}{168} & \multicolumn{2}{|c|}{24} & \multicolumn{2}{|c|}{168} \\
\hline & & & \multirow{2}{*}{$\begin{array}{c}\text { átlag } \\
4,99\end{array}$} & szórás & átlag & szórás & átlag & szórás & átlag & szórás \\
\hline \multirow[t]{8}{*}{ E. coli } & \multirow{2}{*}{$4,5 \mathrm{pH}$} & kontroll & & $\pm 0,07 a$ & 4,65 & $\pm 0,03 a^{*}$ & 5,06 & $\pm 0,08 a$ & \multicolumn{2}{|c|}{$4,59 \pm 0,03 a$} \\
\hline & & kakukkfüolaj & \multicolumn{2}{|c|}{ ND } & 1,96 & $\pm 0,04 \mathrm{~b}$ & \multicolumn{2}{|c|}{ ND } & 2,74 & $\pm 0,05 \mathrm{~b}$ \\
\hline & \multirow[t]{3}{*}{$6,0 \mathrm{pH}$} & kontroll & 5,03 & $\pm 0,02 a$ & 4,59 & $\pm 0,05 a^{*}$ & 4,97 & $\pm 0,08 a$ & 4,55 & $\pm 0,03 a$ \\
\hline & & kakukkfüolaj & 1,82 & $\pm 0,01 \mathrm{~b}$ & & ND & 3,16 & $\pm 0,02 \mathrm{~b}$ & 2,62 & $\pm 0,01 \mathrm{~b}$ \\
\hline & & majoránnaolaj & 1,75 & $\pm 0,02 \mathrm{~b}$ & & ND & 3,28 & $\pm 0,02 \mathrm{~b}$ & 2,09 & $\pm 0,01 \mathrm{c}$ \\
\hline & $8,5 \mathrm{pH}$ & kontroll & 5,05 & $\pm 0,03 a$ & 4,68 & $\pm 0,04 a^{*}$ & 5,01 & $\pm 0,04 a$ & 4,57 & $7 \pm 0,08 a^{2}$ \\
\hline & & kakukkfüolaj & & ND & & ND & 3,56 & $\pm 0,04 \mathrm{~b}$ & 2,27 & $\pm 0,00 \mathrm{~b}$ \\
\hline & & majoránnaolaj & & ND & & ND & 3,33 & $\pm 0,02 \mathrm{c}$ & & ND \\
\hline P. putida & $4,5 \mathrm{pH}$ & kontrol & 5,10 & $\pm 0,09 a$ & 5,03 & $\pm 0,04 a$ & 5,07 & $\pm 0,03 a$ & 5,03 & $\pm 0,09 a$ \\
\hline & & fahéjolaj & & ND & & ND & & ND & & ND \\
\hline & & majoránnaolaj & & ND & & ND & & ND & & ND \\
\hline & $6,0 \mathrm{pH}$ & kontrol & 5,07 & $\pm 0,06 a$ & 5,00 & $\pm 0,02 a$ & 4,97 & $\pm 0,07 a$ & 4,91 & $\pm 0,05 a$ \\
\hline & & fahéjolaj & & ND & & ND & & ND & 2,41 & $\pm 0,03 \mathrm{~b}$ \\
\hline & & majoránnaolaj & & ND & & ND & 1,22 & $\pm 0,00 \mathrm{~b}$ & & ND \\
\hline & $8,5 \mathrm{pH}$ & kontrol & 5,12 & $\pm 0,12 a$ & 5,02 & $\pm 0,05 a$ & 5,04 & $\pm 0,10 a$ & 5,06 & $5 \pm 0,09 a$ \\
\hline & & fahéjolaj & & ND & & ND & & ND & & ND \\
\hline & & majoránnaolaj & 4,44 & $\pm 0,02 \mathrm{~b}$ & 4,02 & $\pm 0,01 \mathrm{~b}$ & 4,24 & $\pm 0,09 \mathrm{~b}$ & 4,47 & $\pm 0,09 \mathrm{~b}$ \\
\hline B. cereus & $6,0 \mathrm{pH}$ & kontroll & 2,61 & $\pm 0,09 a$ & 2,57 & $\pm 0,12 a$ & 2,83 & $\pm 0,19 a$ & 2,64 & $4 \pm 0,15 a$ \\
\hline & & kakukkfüolaj & & ND & & ND & 1,82 & $\pm 0,13 \mathrm{~b}$ & 1,96 & $5 \pm 0,09 \mathrm{~b}$ \\
\hline & & majoránnaolaj & & ND & & ND & 1,62 & $\pm 0,12 \mathrm{~b}$ & 2,07 & $7 \pm 0,16 \mathrm{~b}$ \\
\hline & $8,5 \mathrm{pH}$ & kontroll & 2,64 & $\pm 0,21 a$ & 2,49 & $\pm 0,17 a$ & 2,80 & $\pm 0,25 a$ & 2,74 & $4 \pm 0,24 a$ \\
\hline & & kakukkfüolaj & & ND & & ND & & ND & & ND \\
\hline & & majoránnaolaj & & ND & & ND & & ND & & ND \\
\hline & & fahéjolaj & & ND & & ND & & ND & & ND \\
\hline B. subtilis & $4,5 \mathrm{pH}$ & kontroll & - & - & 2,33 & $\pm 0,18 a^{*}$ & - & - & $2,22 \pm$ & $\pm 0,09 a^{*}$ \\
\hline & & fahéjolaj & - & - & 1,47 & $\pm 0,12 \mathrm{~b}$ & - & - & & ND \\
\hline & & kakukkfüolaj & - & - & & ND & - & - & & ND \\
\hline & & majoránnaolaj & - & - & & ND & - & - & & ND \\
\hline & $6,0 \mathrm{pH}$ & kontroll & - & - & 2,09 & $\pm 0,13 a^{*}$ & - & - & $2,13 \pm$ & $\pm 0,19 a^{*}$ \\
\hline & & fahéjolaj & - & - & & ND & - & - & & ND \\
\hline & & kakukkfüolaj & - & - & & ND & - & - & & ND \\
\hline & & majoránnaolaj & - & - & & ND & - & - & & ND \\
\hline & $8,5 \mathrm{pH}$ & kontroll & - & - & 2,14 & $\pm 0,17 a^{*}$ & - & - & $2,23=$ & $\pm 0,21 a^{*}$ \\
\hline & & fahéjolaj & - & - & & ND & - & - & & ND \\
\hline & & kakukkfüolaj & - & - & & ND & - & - & & ND \\
\hline & & majoránnaolaj & - & - & & ND & - & - & & ND \\
\hline
\end{tabular}


21. táblázat folytatása

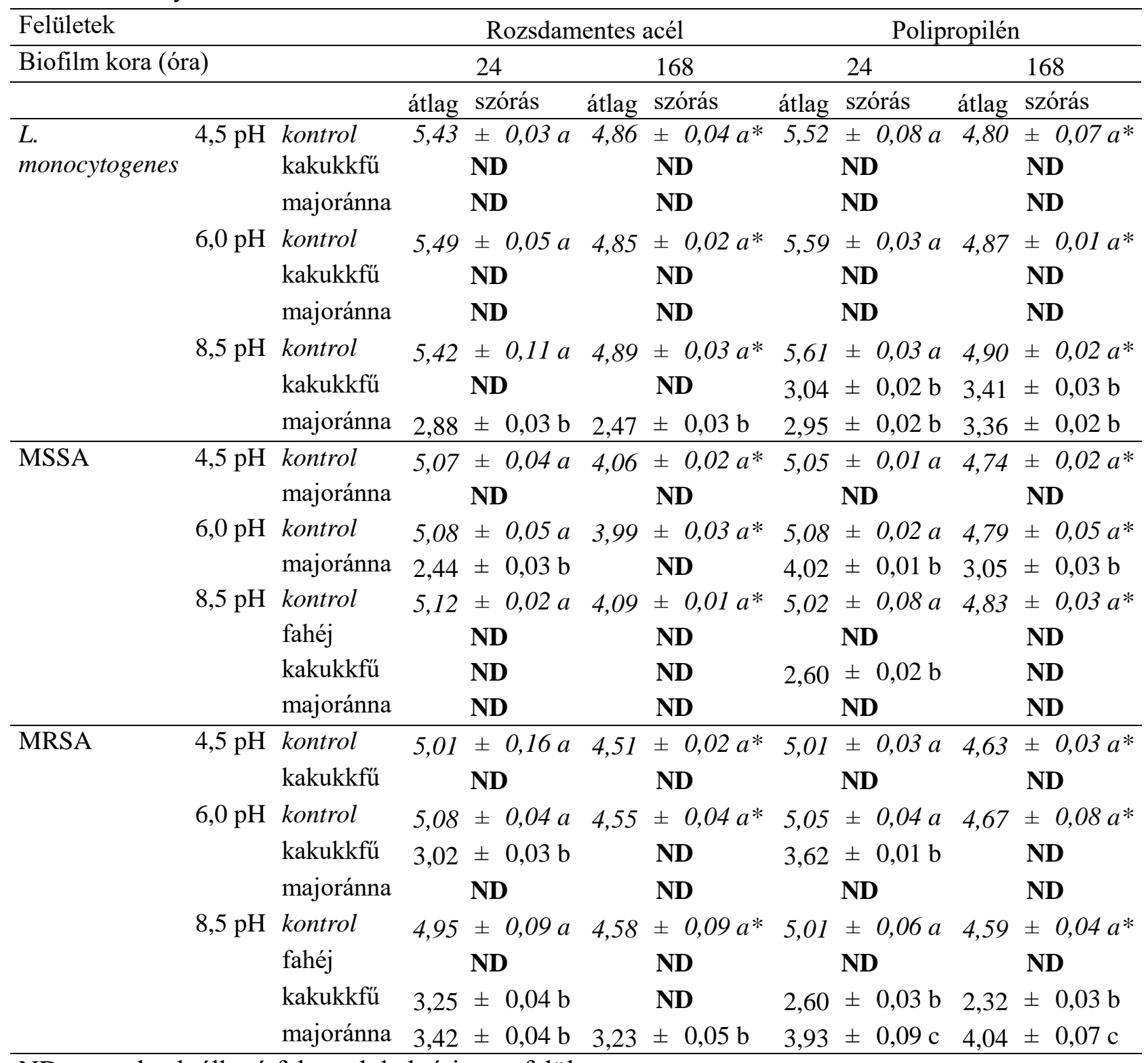

ND: nem detektálható feltapadt baktérium a felületen;

A különböző kisbetük az egy baktériumra vonatkozó kezelések (beleértve a kontrollt is) közötti szignifikáns eltéréseket mutatják $(\mathrm{p}<0,05)$

* a szignifikáns különbséget mutatja a biofilm sejtszámában a biofilm kora alapján $(\mathrm{p}<0,05)$.

$\mathrm{Az}$ 5. ábrán az E. coli sejtek által képzett biofilmen látható a kakukkfüolaj fertőtlenítő hatása. A kakukkfüolaj a 24 órás biofilmet még képes volt teljesen elpusztítani, míg a 168 óráson már csak a sejtszámot tudta csökkenteni. A 168. órára ugyanis már olyan komplex EPS réteg alakulhatott ki, melyen az illóolaj nem tudott megfelelő mértékben áthatolni és mikrobicid hatást kiváltani. 

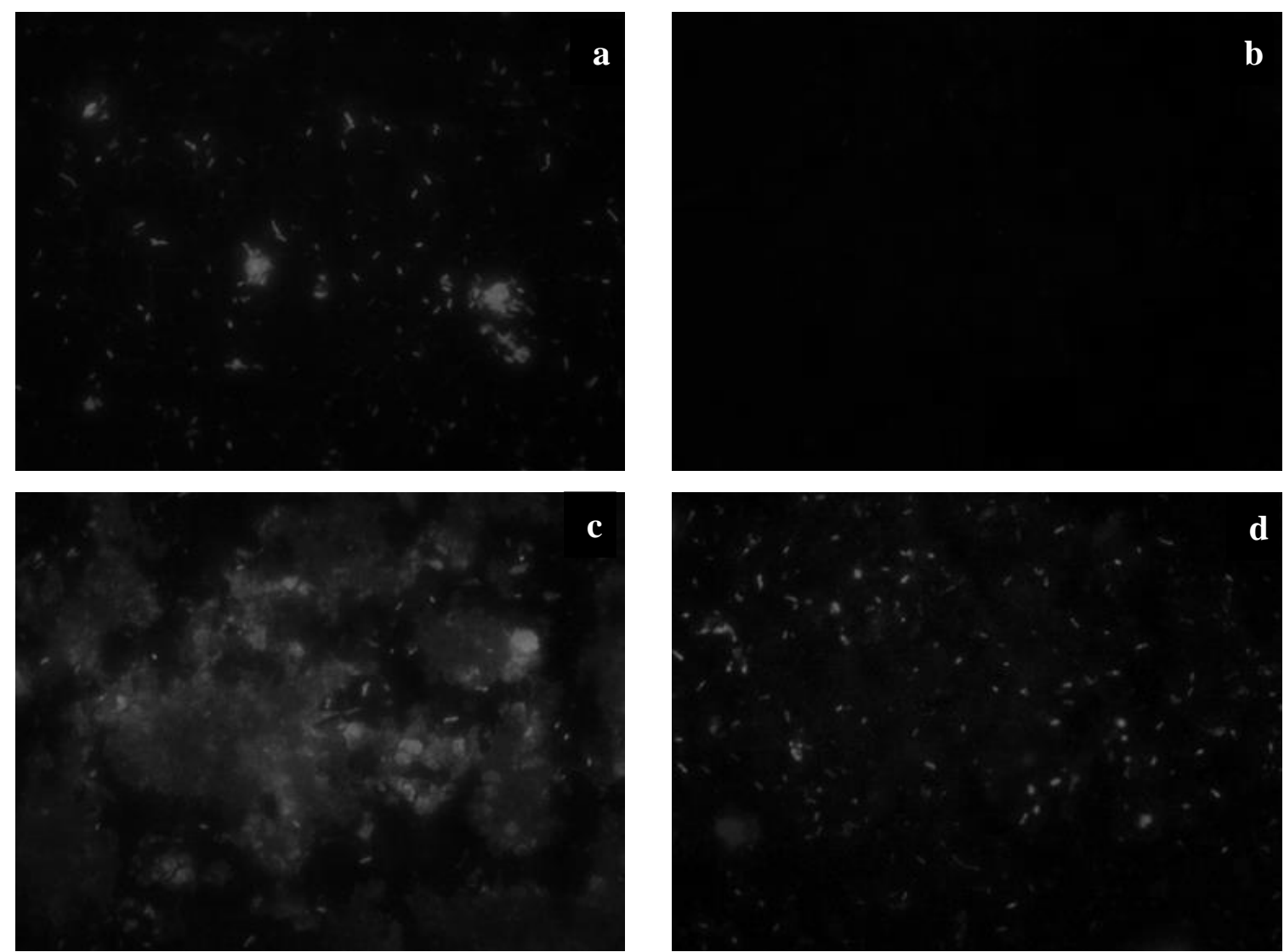

5. ábra. E. coli sejtek által képzett biofilm fertőtlenítés előtt $(\mathrm{a}, \mathrm{c})$ és kezelés után $(\mathrm{b}, \mathrm{d})$ rozsdamentes acélon, akridin-narancsos festés után. A biofilmek kora a és b ábrán 24 óra, míg a c és d ábrán 168 óra. A fertőtlenítés paraméterei: hatóidő 10 perc, kakukkfü illóolaj koncentráció 3,2 mg/ml, pH 4,5.

A 6. ábra jól szemlélteti, hogy az egészségügyben is kockázatot jelentő MRSA biofilmet a kakukkfüolaj hogyan tudta megszüntetni. A fém felületen a 168 órás biofilm összefüggő mátrixot alkotott, amely a kezelés után már nem volt látható a felületen.
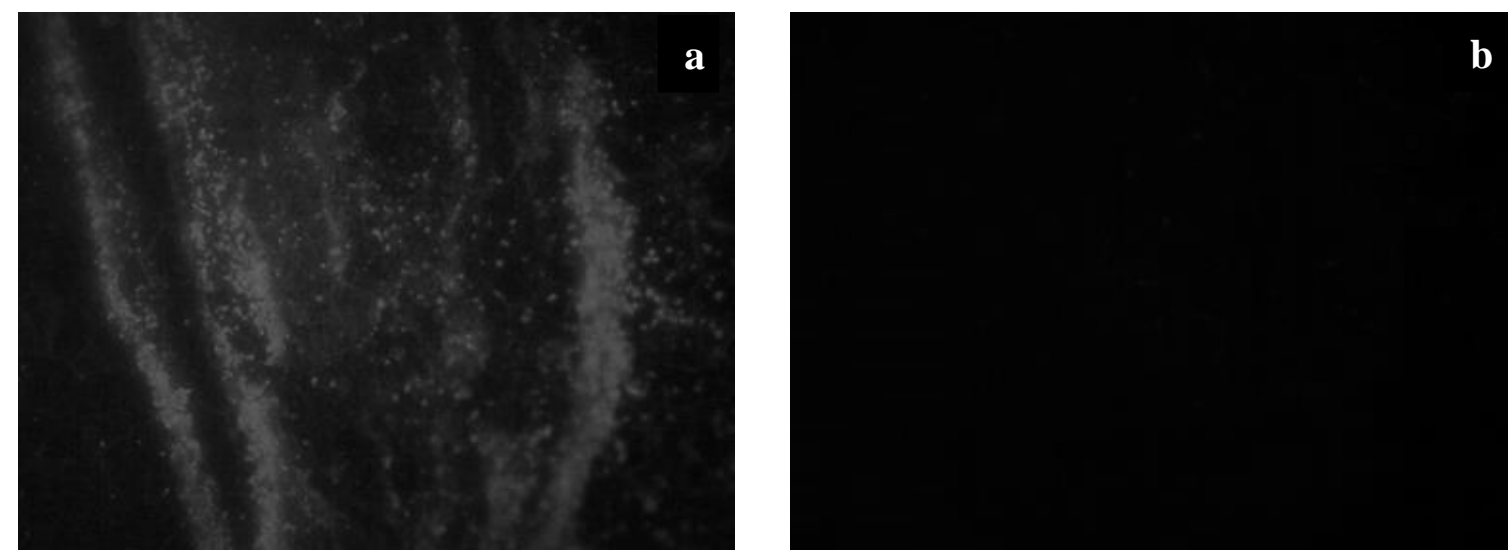

6. ábra. MRSA sejtek által képzett biofilm fertőtlenítés előtt (a) és kezelés után (b) rozsdamentes acélon, akridin-narancsos festés után. A biofilmek kora 168 óra. Fertőtlenítés paraméterei: kakukkfü illóolaj koncentráció 12,5 mg/ml, hatóidö 30 perc, $\mathrm{pH} 4,5$. 
Az ipari üzemböl izolált törzsek esetén is sikerült fertötlenítő hatást elérnünk az alkalmazott felületeken (22. táblázat). Itt sem tudtunk szignifikáns különbséget megállapítani a fém és a müanyag felületen történő biofilm formálás között $(\mathrm{p}>0,05)$. Statisztikailag azonban különbség volt a sejtszámban a 24 és 168 órás biofilm esetén, a 168. órára a biofilmben az élősejtek száma kevesebb volt, melynek hátterében a biofilmek mélyén lévő sejtek pusztulása állhat, ebben a rétegben a legkevesebb az oxigén és a tápanyag.

A két felületet összehasonlítva a rozsdamentes acélon értünk el összességében jobb fertőtlenítési eredményeket. Megállapítottuk, hogy a 168 órás biofilmekre jobb hatásuk volt az illóolajos fertőtlenítőszereknek. Kivételt jelentett az Escherichia izolátum, ugyanis ezen a baktériumon hatottak legkevésbé az illóolajos fertőtlenítőszerek. Ez a jelenség a törzsgyüjteményből származó E. coli esetén is megfigyelhető volt (21. táblázat). A 22. táblázat adatai alapján egyöntetüen elmondható, hogy a savas kémhatású illóolajos fertőtlenítőszer hatott jobban, ezek közül is a majoránna illóolaj.

Bae és munkatársai (2012) klór alapú fertőtlenítőszert vizsgáltak, ahol a S. aureus sejtekből képzett biofilm nem pusztult el 5 perces fertőtlenítési idő után. Az általunk vizsgált illóolajok esetében több időre volt ugyan szükség, de 100\%-os hatást tudtunk elérni. Chorianopoulos és munkatársai (2008) egy növényi kivonatot és különböző fertőtlenítőszereket hasonlítottak össze, ahol a növényi kivonatnak jobb baktericid hatása volt 5 napos L. monocytogenes, P. putida és Staphylococcus simulans biofilmen. Warnke és munkatársai (2009) kísérletükben azt tapasztalták, hogy S. aureus sejtekböl képzett biofilm elpusztításához kétszer több hidrogén peroxid kellett, mint fahéj illóolaj. A növényi kivonatok természetesek és ritkán alakul ki rezisztencia ellenük, mivel összetételükben az egyes kiszerelések között lehet kisebb arányú változás (Sieniawska és mtsi., 2013). Emellett fontos megemlíteni, hogy az általunk végzett kísérletekben 100\%-os hatást tudtunk elérni olyan patogéneken, mint a $S$. aureus, az MRSA és a $L$. monocytogenes, mely baktériumok számos élelmiszer eredetű járvány kitörésének hátterében állhatnak és a kórházi fertőzések között is megjelennek (Bae és mtsi., 2012). Ezen eredmények alapján, az alternatív fertőtlenítőszernek savas kémhatásúnak és elsősorban majoránna illóolaj tartalmunak kell lennie. 
22. táblázat. Biofilm eliminálás eredményei: túlélő baktériumszám $\left(\log \mathrm{CFU} / \mathrm{cm}^{2}\right)$ ipari izolátumok esetén.

\begin{tabular}{|c|c|c|c|c|c|c|c|c|c|c|}
\hline \multirow{2}{*}{$\begin{array}{l}\text { Felület } \\
\text { Biofilm kora (óra) }\end{array}$} & & & \multicolumn{4}{|c|}{ Rozsdamentes acél } & \multicolumn{4}{|c|}{ Polipropilén } \\
\hline & & & \multicolumn{2}{|r|}{24} & \multicolumn{2}{|c|}{168} & \multicolumn{2}{|r|}{24} & \multicolumn{2}{|r|}{168} \\
\hline & & & átlag & szórás & átlag & szórás & átlag & szórás & átlag & szórás \\
\hline \multirow[t]{8}{*}{ Citrobacter sp. } & $4,5 \mathrm{pH}$ & kontroll & 5,00 & $\pm 0,03 a$ & 4,42 & $\pm 0,07 a^{*}$ & 5,02 & $\pm 0,08 a$ & 4,35 & $\pm 0,05 a^{*}$ \\
\hline & & fahéjolaj & 0,87 & $\pm 0,02 \mathrm{~b}$ & 1,32 & $\pm \quad 0,01 \mathrm{~b}$ & 1,49 & $\pm 0,02 \mathrm{~b}$ & 1,43 & $\pm \quad 0,03 \mathrm{~b}$ \\
\hline & & kakukkfüolaj & \multicolumn{2}{|c|}{ ND } & \multicolumn{2}{|r|}{ ND } & \multicolumn{2}{|c|}{ ND } & \multicolumn{2}{|c|}{ ND } \\
\hline & & majoránnaolaj & \multicolumn{2}{|r|}{ ND } & \multicolumn{2}{|c|}{ ND } & \multicolumn{2}{|r|}{ ND } & \multicolumn{2}{|r|}{ ND } \\
\hline & \multirow[t]{4}{*}{$6,0 \mathrm{pH}$} & kontroll & 5,03 & $\pm \quad 0,04 a$ & 4,29 & $\pm 0,03 a^{*}$ & 5,00 & $\pm 0,08 a$ & 4,26 & $\pm 0,12 a^{*}$ \\
\hline & & fahéjolaj & 0,67 & $\pm 0,02 \mathrm{~b}$ & 1,54 & $\pm \quad 0,04 \mathrm{~b}$ & 1,88 & $\pm 0,02 \mathrm{~b}$ & 1,37 & $\pm \quad 0,01 \mathrm{~b}$ \\
\hline & & kakukkfüolaj & 1,66 & $\pm 0,05 \mathrm{c}$ & \multirow{2}{*}{\multicolumn{2}{|c|}{$\begin{array}{l}\text { ND } \\
\text { ND } \\
\end{array}$}} & 1,37 & $\pm 0,01 \mathrm{c}$ & \multirow{2}{*}{\multicolumn{2}{|c|}{$\begin{array}{l}\text { ND } \\
\text { ND }\end{array}$}} \\
\hline & & majoránnaolaj & & ND & & & 1,03 & $0,01 \mathrm{c}$ & & \\
\hline \multirow[t]{6}{*}{ Serratia sp. } & \multirow[t]{3}{*}{$4,5 \mathrm{pH}$} & kontroll & 4,46 & $\pm 0,05 a$ & 4,31 & $\pm 0,04 a$ & 4,50 & $\pm 0,04 a$ & 4,39 & $\pm 0,05 a$ \\
\hline & & fahéjolaj & \multicolumn{2}{|c|}{ ND } & \multicolumn{2}{|c|}{ ND } & \multicolumn{2}{|c|}{ ND } & \multicolumn{2}{|c|}{ ND } \\
\hline & & kakukkfüolaj & \multicolumn{2}{|r|}{ ND } & \multicolumn{2}{|r|}{ ND } & \multicolumn{2}{|r|}{ ND } & \multicolumn{2}{|r|}{ ND } \\
\hline & \multirow[t]{3}{*}{$6,0 \mathrm{pH}$} & kontroll & 4,55 & $\pm \quad 0,03 a$ & 4,25 & $\pm \quad 0,21 a$ & 4,54 & $\pm 0,20 a$ & 4,47 & $\pm 0,06 a$ \\
\hline & & fahéjolaj & 2,11 & $\pm 0,01 \mathrm{~b}$ & & ND & 1,19 & $\pm 0,02 \mathrm{~b}$ & 1,28 & $\pm 0,03 \mathrm{~b}$ \\
\hline & & kakukkfüolaj & \multicolumn{2}{|c|}{ ND } & & ND & & ND & & ND \\
\hline Enterobacter sp. & $4,5 \mathrm{pH}$ & kontroll & 4,83 & $\pm 0,02 a$ & 4,51 & $\pm \quad 0,04 a$ & 4,93 & $\pm 0,04 a$ & 4,71 & $\pm 0,04 a^{*}$ \\
\hline & & fahéjolaj & & ND & & ND & & ND & & ND \\
\hline & & kakukkfüolaj & & ND & & ND & & ND & & ND \\
\hline & & majoránnaolaj & & ND & & ND & & ND & & ND \\
\hline & $6,0 \mathrm{pH}$ & kontroll & 4,97 & $\pm \quad 0,04 a$ & 4,24 & $\pm \quad 0,04 a$ & 5,03 & $\pm \quad 0,04 a$ & 4,29 & $\pm \quad 0,02 a^{*}$ \\
\hline & & fahéjolaj & & ND & & ND & 1,15 & $0,01 \mathrm{~b}$ & 0,99 & $0,05 \mathrm{~b}$ \\
\hline & & kakukkfüolaj & & ND & & ND & 1,82 & $0,02 \mathrm{c}$ & 1,65 & $0,02 \mathrm{c}$ \\
\hline & & majoránnaolaj & & ND & & ND & 1,11 & $0,01 \mathrm{~b}$ & 1,09 & $0,03 \mathrm{~b}$ \\
\hline
\end{tabular}




\begin{tabular}{|c|c|c|c|c|c|c|c|c|c|c|}
\hline \multirow{2}{*}{$\begin{array}{l}\text { Felület } \\
\text { Biofilm kora (óra) }\end{array}$} & & & \multicolumn{4}{|c|}{ Rozsdamentes acél } & \multicolumn{4}{|c|}{ Polipropilén } \\
\hline & & & \multicolumn{2}{|r|}{24} & \multicolumn{2}{|c|}{168} & \multicolumn{2}{|r|}{24} & \multicolumn{2}{|r|}{168} \\
\hline & & & átlag & szórás & átlag & szórás & átlag & szórás & átlag & szórás \\
\hline \multirow[t]{8}{*}{ Escherichia sp. } & $4,5 \mathrm{pH}$ & kontroll & 4,08 & $\pm 0,06 a$ & 3,63 & $\pm 0,05 a^{*}$ & 4,02 & $\pm 0,04 a$ & 3,59 & $\pm 0,10 a^{*}$ \\
\hline & & fahéjolaj & 1,11 & $\pm 0,03 \mathrm{~b}$ & 1,02 & $\pm \quad 0,03 \mathrm{~b}$ & 1,21 & $\pm \quad 0,04 \mathrm{~b}$ & 1,10 & $\pm \quad 0,03 \mathrm{~b}$ \\
\hline & & kakukkfüolaj & \multicolumn{2}{|c|}{ ND } & \multicolumn{2}{|c|}{ ND } & \multicolumn{2}{|c|}{ ND } & \multicolumn{2}{|c|}{ ND } \\
\hline & & majoránnaolaj & \multicolumn{2}{|r|}{ ND } & \multicolumn{2}{|r|}{ ND } & \multicolumn{2}{|r|}{ ND } & \multicolumn{2}{|r|}{ ND } \\
\hline & \multirow[t]{4}{*}{$6,0 \mathrm{pH}$} & kontroll & 4,09 & $\pm \quad 0,01 a$ & 3,55 & $\pm 0,03 a^{*}$ & 4,09 & $\pm \quad 0,01 a$ & 3,52 & $\pm 0,03 a^{*}$ \\
\hline & & fahéjolaj & 2,06 & $\pm 0,03 \mathrm{~b}$ & 2,12 & $\pm \quad 0,04 \mathrm{~b}$ & 1,50 & $\pm 0,04 \mathrm{~b}$ & 2,47 & $\pm 0,06 \mathrm{~b}$ \\
\hline & & kakukkfüolaj & 1,83 & $\pm 0,01 \mathrm{c}$ & 2,49 & $\pm 0,06 \mathrm{c}$ & 2,00 & $\pm 0,07 \mathrm{c}$ & 2,15 & $\pm \quad 0,03 \mathrm{c}$ \\
\hline & & majoránnaolaj & \multicolumn{2}{|c|}{ ND } & \multicolumn{2}{|c|}{ ND } & \multicolumn{2}{|r|}{ ND } & \multicolumn{2}{|r|}{ ND } \\
\hline \multirow[t]{8}{*}{ Pseudomonas sp. } & $4,5 \mathrm{pH}$ & kontroll & 4,63 & $\pm 0,07 a$ & 4,38 & $\pm 0,09 a$ & 4,72 & $\pm 0,07 a$ & 4,46 & $\pm 0,02 a$ \\
\hline & & fahéjolaj & \multicolumn{2}{|r|}{ ND } & \multicolumn{2}{|r|}{ ND } & \multicolumn{2}{|r|}{ ND } & \multicolumn{2}{|r|}{ ND } \\
\hline & & kakukkfüolaj & 1,23 & $\pm \quad 0,02 \mathrm{~b}$ & 1,01 & $\pm \quad 0,03 \mathrm{~b}$ & 1,56 & $\pm \quad 0,04 \mathrm{~b}$ & 1,14 & $\pm \quad 0,02 \mathrm{~b}$ \\
\hline & & majoránnaolaj & \multicolumn{2}{|r|}{ ND } & \multicolumn{2}{|r|}{ ND } & \multicolumn{2}{|r|}{ ND } & \multicolumn{2}{|r|}{ ND } \\
\hline & \multirow[t]{4}{*}{$6,0 \mathrm{pH}$} & kontroll & 4,59 & $\pm \quad 0,12 a$ & 4,45 & $\pm \quad 0,80 a$ & 4,70 & $\pm \quad 0,01 a$ & 4,62 & $\pm \quad 0,03 a$ \\
\hline & & fahéjolaj & \multicolumn{2}{|r|}{ ND } & \multicolumn{2}{|r|}{ ND } & \multicolumn{2}{|r|}{ ND } & & ND \\
\hline & & kakukkfüolaj & 1,89 & $\pm \quad 0,07 \mathrm{~b}$ & 0,91 & $\pm \quad 0,02 \mathrm{~b}$ & 2,19 & $\pm \quad 0,04 \mathrm{~b}$ & 1,18 & $\pm \quad 0,04 \mathrm{~b}$ \\
\hline & & majoránnaolaj & & ND & & ND & & ND & & ND \\
\hline
\end{tabular}

ND: nem detektálható feltapadt baktérium a felületen;

A különböző kisbetűk az egy baktériumra vonatkozó kezelések (beleértve a kontrollt is) közötti szignifikáns eltéréseket mutatják (p<0,05)

* a szignifikáns különbséget mutatja a biofilm sejtszámában a biofilm kora alapján $(\mathrm{p}<0,05)$. 


\subsection{Az ipari és az illóolajos fertőtlenítőszer összehasonlítása vegyes tenyészeten}

A vegyes biofilmet alkotó baktériumok az élelmiszer szektorban jelentős gondot tudnak okozni, főként a nyers vagy készen vásárolt élelmiszerek esetében kell nagyobb kockázattal számolni (Shi és Zhu, 2009; Srey és mtsi., 2009). A kísérleteinkben vizsgált baktériumok képesek voltak közös biofilmet létrehozni. Huszonnégy óra elteltével a legmagasabb sejtszámú biofilm a fa felületen alakult ki, míg a leggyengébb biofilm képzés a fém felületen volt megfigyelhető (23.-24. táblázat). A 168 órás biofilmeknél már nem volt szignifikáns különbség a fém, műanyag és csempe felületen kialakuló biofilmek sejtszámában $(\mathrm{p}>0,05)$. A felületek közötti fö különbség a felületi érdesség több szerző szerint, amely jelentősen befolyásolja a sejtek kitapadását (Kumar és Anand, 1998; Phillips, 2016; Tuson és Weibel, 2013). A fa felületen végzett kutatások száma elenyésző (Aviat és mtsi., 2016), míg a csempe felülettel kapcsolatban egyáltalán nem találtunk publikációt az általunk ismert szakirodalomban. A kísérletek során gyakran vizsgált felületek a következők: rozsdamentes acél (Chorianopoulos és mtsi., 2008; Desai és mtsi., 2012; da Silva Fernandes és mtsi., 2015; Gomes és mtsi., 2016; Koo és mtsi., 2013; Langsrud és mtsi., 2016; Soni és mtsi., 2013); mủanyag (Desai és mtsi., 2012; Soni és mtsi., 2013); szilikon (Ariani és mtsi., 2015; Gomes és mtsi., 2016).

Kísérleteinkben a baktériumok száma több volt a 24 órás biofilmben, mint a 168 órásban. A 7. ábra foglalja össze az egyes baktériumok arányát a biofilmekben. A vegyes populációban a baktériumok aránya eltolódott a 168. óra végére a Gram negatív baktériumok irányába ( $P$. putida, E. coli).

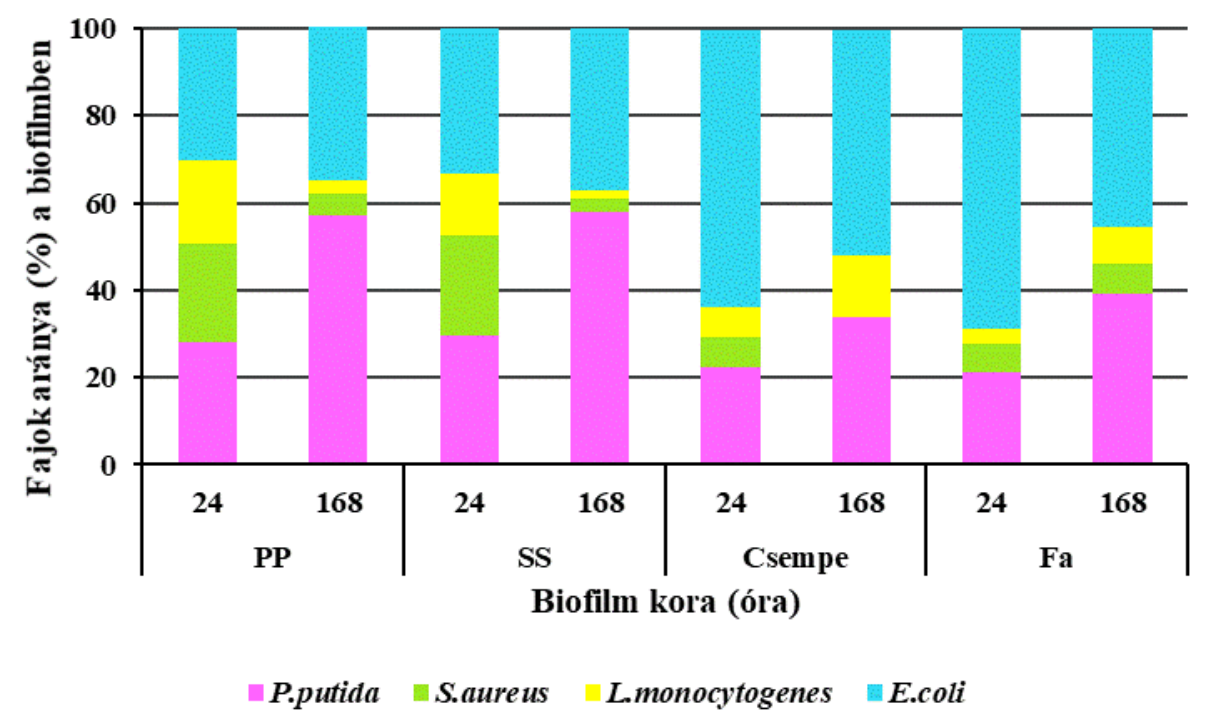

7. ábra. A fajok aránya (\%) a vegyes tenyészetü biofilmben a 24. és a 168. órában. PP: polipropilén, SS: rozsdamentes acél 
A 23.-24. táblázatban a 24 és 168 órás vegyes tenyészetből álló biofilmek eliminálási kísérletének eredményei láthatók. Az eredmények összegzésével elmondhatjuk, hogy savasabb környezetben az illóolajoknak jobb volt a fertőtlenítő hatásuk, mint a lúgos közegben. A PP, SS és csempe esetén szinte minden esetben teljes biofilm eliminálást értünk el az illóolajokkal. A fa felületről a baktérium mátrix eltávolítása nagyon nehéz volt a felület egyenetlensége miatt, ebben az esetben csak szignifikáns $(\mathrm{p}<0,05)$ sejtszámbeli csökkenést értünk el a legtöbb esetben (23.-24. táblázat). Rhoades és munkatársai (2013) hasonló megállapításra jutottak: oregánó illóolajjal a fém felületen jobb hatást értek el, mint a müanyag vagy fa felületen.

A csempe felület a fához hasonlóan viselkedett, habár ebben az esetben a baktériumok többségénél szignifikánsan csökkent a sejtszám a kontrollhoz képest $(\mathrm{p}<0,05)$. Csempe felületen a fa felülethez képes a L. monocytogenes és a $S$. aureus már nem volt jelen az illóolajos kezelések után, sikerült elpusztítani ezen patogéneket.

$\mathrm{Az}$ eredmények alapján általánosságban felírható egy sorrend a különböző fertőtlenítők között: savas kémhatatású illóolajos fertőtlenítők > illóolajos fertőtlenítők 6 pH-n, HC-DPE > lúgos kémhatású fertőtlenítők.

Egyöntetűen megállapítható volt az is, hogy a lúgos fertőtlenítőszer jobban hatott az L. monocytogenes sejtszámára, mint a savas. A baktériumok száma a biofilmben különböző volt. Mivel a biofilm egy háromdimenziós képződmény, ennek megfelelően mások a környezeti viszonyok a felületen és a biofilm belsejében. Felülröl lefelé haladva csökken az oxigén és a tápanyagok mennyisége, így mikroaerofil környezet alakul ki a biofilm alján (Gupta és mtsi., 2016). Giaouris és munkatársai (2015) tanulmányában a háromfajos vegyes tenyészet esetén az $E$. coli volt legnagyobb arányban megtalálható a $L$. monocytogenes és a S. enterica mellett. A mi kísérletünkben is, a fiatal és érett biofilmben egyaránt, az E. coli volt nagyobb arányban jelen a többi baktériumhoz képest. Chorianopoulos és munkatársai (2008) megállapították, hogy a vegyes biofilmben versengés van a tápanyagért, emiatt a $P$. putida volt jelen a legnagyobb sejtszámmal a mátrixban, utána a Listeria és a Salmonella fajok, míg a Lactobacillus fermentum detektálási szint alatt $(0,03 \log \mathrm{CFU} / \mathrm{ml})$ maradt. Ez az általunk kapott eredményeket is alátámasztja, mivel a $P$. putida az $E$. coli-val szinte hasonló sejtszámban volt jelen. 
23. táblázat. 24 órás biofilm eliminálás eredményei: túlélő baktériumszám (átlag \pm szórás $\log \mathrm{CFU} / \mathrm{cm}^{2}$ ) vegyes tenyészet esetén és baktériumonként.

\begin{tabular}{|c|c|c|c|c|c|c|c|c|c|c|c|}
\hline & \multirow{2}{*}{ Baktérium } & \multirow{2}{*}{ Kontroll } & \multirow{2}{*}{ HC-DPE } & \multicolumn{3}{|l|}{$4,5 \mathrm{pH}$} & \multicolumn{3}{|l|}{$6,0 \mathrm{pH}$} & \multicolumn{2}{|l|}{$8,5 \mathrm{pH}$} \\
\hline & & & & Fahéj & Majoránna & Kakukkfü & Fahéj & Majoránna & Kakukkfü & Majoránna & Kakukkfü \\
\hline \multirow{5}{*}{ 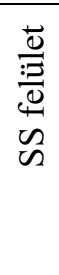 } & S. $a$ & $3,67 \pm 0,04$ & ND & ND & ND & ND & ND & ND & ND & ND & ND \\
\hline & $P . p$ & $3,99 \pm 0,02$ & ND & ND & ND & ND & ND & ND & ND & $3,84 \pm 0,05$ & $2,95 \pm 0,09$ \\
\hline & E. $c$ & $4,05 \pm 0,03$ & ND & ND & ND & ND & ND & ND & ND & ND & ND \\
\hline & L. $m$ & $3,51 \pm 0,01$ & ND & ND & ND & ND & ND & ND & ND & ND & ND \\
\hline & Összes & $4,40 \pm 0,08 \mathrm{a}$ & ND & ND & ND & ND & ND & ND & ND & $3,87 \pm 0,10 \mathrm{~b}$ & $3,02 \pm 0,11 \mathrm{c \#}$ \\
\hline \multirow{5}{*}{ 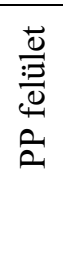 } & S. $a$ & $3,70 \pm 0,03$ & ND & ND & ND & ND & ND & ND & ND & ND & ND \\
\hline & P. $p$ & $4,12 \pm 0,02$ & ND & ND & ND & ND & ND & ND & ND & $3,67 \pm 0,15$ & $2,74 \pm 0,06$ \\
\hline & E. $c$ & $4,29 \pm 0,03$ & ND & ND & $3,40 \pm 0,09$ & ND & ND & ND & ND & ND & ND \\
\hline & L. $m$ & $3,60 \pm 0,03$ & ND & ND & ND & ND & ND & ND & ND & ND & ND \\
\hline & Összes & $4,6 \pm 0,04 \mathrm{a}$ & ND & ND & $3,41 \pm 0,14 \mathrm{~b}$ & ND & ND & ND & ND & $3,68 \pm 0,16 b$ & $2,75 \pm 0,07 \mathrm{c \#}$ \\
\hline \multirow{5}{*}{ 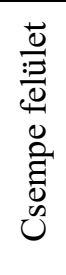 } & S. $a$ & $3,82 \pm 0,01$ & $3,28 \pm 0,03$ & ND & ND & ND & ND & ND & ND & $3,49 \pm 0,03$ & ND \\
\hline & $P . p$ & $4,25 \pm 0,03$ & $3,66 \pm 0,02$ & ND & ND & ND & ND & ND & ND & $3,18 \pm 0,07$ & ND \\
\hline & E. $c$ & $4,43 \pm 0,02$ & $3,89 \pm 0,06$ & $3,70 \pm 0,04$ & $3,67 \pm 0,05$ & $3,74 \pm 0,03$ & $3,61 \pm 0,05$ & $2,99 \pm 0,04$ & $3,60 \pm 0,06$ & $4,33 \pm 0,02$ & $4,68 \pm 0,03$ \\
\hline & L. $m$ & $3,83 \pm 0,04$ & $2,72 \pm 0,02$ & ND & ND & ND & ND & ND & ND & $3,76 \pm 0,01$ & ND \\
\hline & Összes & $4,81 \pm 0,06 \mathrm{a}$ & $4,13 \pm 0,06 \mathrm{~b} * \#$ & $3,76 \pm 0,17 b^{*}$ & $3,71 \pm 0,07 b^{*}$ & $3,82 \pm 0,02 b^{*}$ & $3,61 \pm 0,09 b^{*}$ & $2,98 \pm 0,07 \mathrm{c}^{*}$ & $3,67 \pm 0,05 \mathrm{~b}^{*}$ & $4,81 \pm \pm 0,03 \mathrm{a}^{*}$ & $4,73 \pm 0,04 \mathrm{a}^{* \#}$ \\
\hline \multirow{5}{*}{ 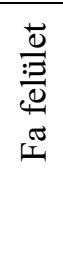 } & S. $a$ & $4,23 \pm 0,05$ & $3,82 \pm 0,05$ & ND & ND & ND & ND & ND & ND & $3,88 \pm 0,06$ & $4,12 \pm 0,02$ \\
\hline & $P . p$ & $4,39 \pm 0,06$ & $3,97 \pm 0,02$ & $3,4 \pm 0,02$ & $3,08 \pm 0,04$ & ND & $4,03 \pm 0,09$ & $4,11 \pm 0,07$ & $4,19 \pm 0,05$ & $4,34 \pm 0,03$ & $4,34 \pm 0,04$ \\
\hline & E. $c$ & $4,61 \pm 0,02$ & $4,01 \pm 0,05$ & $4,1 \pm 0,05$ & $3,34 \pm 0,07$ & $3,41 \pm 0,05$ & $4,02 \pm 0,04$ & $4,22 \pm 0,04$ & $4,25 \pm 0,06$ & $4,54 \pm 0,03$ & $4,56 \pm 0,02$ \\
\hline & L. $m$ & $4,15 \pm 0,03$ & $3,60 \pm 0,04$ & ND & ND & ND & ND & ND & ND & $3,72 \pm 0,05$ & $3,95 \pm 0,03$ \\
\hline & Összes & $5,13 \pm 0,10 \mathrm{a}$ & $4,44 \pm 0,09 \mathrm{~b} * \#$ & $4,18 \pm 0,12 b^{*}$ & $3,45 \pm 0,07 \mathrm{c}^{*}$ & $3,41 \pm 0,06 c^{*}$ & $4,21 \pm 0,06 b^{*}$ & $4,32 \pm 0,08 b^{*}$ & $4,51 \pm 0,09 \mathrm{~b}^{*}$ & $4,95 \pm 0,06 \mathrm{a}^{*}$ & $5,05 \pm 0,06 \mathrm{a}^{* \#}$ \\
\hline
\end{tabular}

S. a: S. aureus, P. p: P. putida, E. c: E. coli, L. m: L. monocytogenes. SD: szórás; ND: nem detektálható feltapadt baktérium a felületen; a különböző kisbetük az egy baktériumra vonatkozó kezelések (beleértve a kontrollt is) közötti szignifikáns eltéréseket mutatják ( $<<0,05)$; *: a szignifikáns különbséget mutatja a felületek között; \#: a szignifikáns különbséget mutatja a különböző kezelések összessége között (HC-DPE - 4,5 pH - 6,0 pH - 8,5 pH) (p<0,05). 
24. táblázat. 168 órás biofilm eliminálás eredményei: túlélő baktériumszám (átlag \pm szórás log CFU/cm²) vegyes tenyészet esetén és baktériumonként.

\begin{tabular}{|c|c|c|c|c|c|c|c|c|c|c|c|}
\hline & \multirow{2}{*}{ Baktérium } & \multirow{2}{*}{ Kontroll } & \multirow{2}{*}{ HC-DPE } & \multicolumn{3}{|l|}{$4,5 \mathrm{pH}$} & \multicolumn{3}{|l|}{$6,0 \mathrm{pH}$} & \multicolumn{2}{|l|}{$8,5 \mathrm{pH}$} \\
\hline & & & & Fahéj & Majoránna & Kakukkfü & Fahéj & Majoránna & Kakukkfü & Majoránna & Kakukkfü \\
\hline \multirow{5}{*}{ 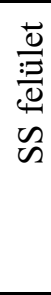 } & S. $a$ & $2,82 \pm 0,02$ & ND & ND & ND & ND & ND & ND & ND & ND & ND \\
\hline & $P . p$ & $4,12 \pm 0,03$ & ND & ND & ND & ND & ND & ND & ND & ND & ND \\
\hline & E. $c$ & $3,93 \pm 0,06$ & ND & ND & ND & ND & ND & ND & ND & ND & ND \\
\hline & L. $m$ & $2,54 \pm 0,04$ & ND & ND & ND & ND & ND & ND & ND & ND & ND \\
\hline & Összes & $4,32 \pm 0,12$ & ND & ND & ND & ND & ND & ND & ND & ND & ND \\
\hline \multirow{5}{*}{ 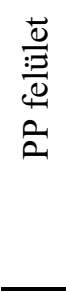 } & S. $a$ & $3,11 \pm 0,08$ & ND & ND & ND & ND & ND & ND & ND & ND & ND \\
\hline & $P . p$ & $4,21 \pm 0,07$ & ND & ND & ND & ND & ND & ND & ND & $2,65 \pm 0,04$ & ND \\
\hline & E. $c$ & $4,00 \pm 0,08$ & ND & ND & ND & ND & ND & ND & ND & ND & ND \\
\hline & L. $m$ & $2,91 \pm 0,07$ & ND & ND & ND & ND & ND & ND & ND & ND & ND \\
\hline & Összes & $4,45 \pm 0,07 \mathrm{a}$ & ND & ND & ND & ND & ND & ND & ND & $2,72 \pm 0,07 b^{*}$ & ND \\
\hline \multirow{5}{*}{ 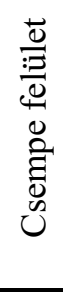 } & S. $a$ & $3,40 \pm 0,02$ & ND & ND & ND & ND & ND & ND & ND & ND & ND \\
\hline & $P . p$ & $4,21 \pm 0,02$ & $3,52 \pm 0,01$ & $3,02 \pm 0,01$ & $3,71 \pm 0,09$ & $3,78 \pm 0,05$ & $3,01 \pm 0,03$ & $2,86 \pm 0,06$ & $2,56 \pm 0,02$ & $4,09 \pm 0,04$ & $3,64 \pm 0.05$ \\
\hline & E. $c$ & $4,08 \pm 0,06$ & $3,30 \pm 0,03$ & $2,87 \pm 0,05$ & $3,01 \pm 0,07$ & $3,09 \pm 0,07$ & $2,97 \pm 0,08$ & $2,81 \pm 0,02$ & $2,23 \pm 0,05$ & $4,23 \pm 0,08$ & ND \\
\hline & L. $m$ & $3,23 \pm 0,04$ & ND & ND & ND & ND & ND & ND & ND & ND & ND \\
\hline & Összes & $4,51 \pm 0,03 \mathrm{a}$ & $3,69 \pm 0,06 \mathrm{~b}^{*}$ & $3,18 \pm 0,03 \mathrm{c}^{*}$ & $3,76 \pm 0,09 \mathrm{~b}^{*}$ & $3,85 \pm 0,04 \mathrm{~b}^{*}$ & $3,12 \pm 0,06 c^{*}$ & $3,02 \pm 0,04 \mathrm{c}^{*}$ & $2,68 \pm 0,07 \mathrm{~d}^{*}$ & $4,36 \pm 0,06 \mathrm{a}^{*}$ & $3,64 \pm 0,05 \mathrm{~b} * \#$ \\
\hline \multirow{5}{*}{ 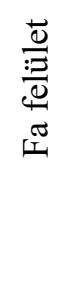 } & S. $a$ & $4,00 \pm 0,03$ & $3,41 \pm 0,07$ & $1,78 \pm 0,04$ & $1,54 \pm 0,01$ & $1,62 \pm 0,03$ & $4,02 \pm 0,06$ & $3,99 \pm 0,03$ & $3,72 \pm 0,05$ & $3,78 \pm 0,03$ & $2,81 \pm 0,07$ \\
\hline & P. $p$ & $4,41 \pm 0,06$ & $4,19 \pm 0,05$ & $4,14 \pm 0,03$ & $3,91 \pm 0,05$ & $4,13 \pm 0,05$ & $4,42 \pm 0,0,3$ & $4,21 \pm 0,05$ & $4,11 \pm 0,09$ & $4,23 \pm 0,05$ & $4,00 \pm 0,05$ \\
\hline & E. $c$ & $4,35 \pm 0,04$ & $4,12 \pm 0,04$ & $4,00 \pm 0,03$ & $4,01 \pm 0,03$ & $4,34 \pm 0,07$ & $4,25 \pm 0,08$ & $4,32 \pm 0,06$ & $4,05 \pm 0,07$ & $4,21 \pm 0,03$ & $3,93 \pm 0,09$ \\
\hline & L. $m$ & $3,71 \pm 0,04$ & $3,49 \pm 0,05$ & $3,77 \pm 0,07$ & $3,71 \pm 0,06$ & $3,91 \pm 0,03$ & $3,96 \pm 0,10$ & $3,81 \pm 0,06$ & $3,61 \pm 0,03$ & $3,63 \pm 0,08$ & $2,14 \pm 006$ \\
\hline & Összes & $4,84 \pm 0,05 \mathrm{a}$ & $4,55 \pm 0,05 b^{*}$ & $4,52 \pm 0,03 b^{*}$ & $4,31 \pm 0,06 \mathrm{c}^{*}$ & $4,72 \pm 0,05 \mathrm{a}^{*}$ & $4,89 \pm 0,09 \mathrm{a}^{*}$ & $4,73 \pm 0,07 a^{*}$ & $4,23 \pm 0,05 \mathrm{c}^{*}$ & $4,72 \pm 0,09 \mathrm{a}^{*}$ & $4,22 \pm 0,18 \mathrm{c}^{*}$ \\
\hline
\end{tabular}

S. a: S. aureus, P. p: P. putida, E. c: E. coli, L. m: L. monocytogenes. SD: szórás; ND: nem detektálható feltapadt baktérium a felületen; a különböző kisbetük az egy baktériumra vonatkozó kezelések (beleértve a kontrollt is) közötti szignifikáns eltéréseket mutatják; a * a szignifikáns különbséget mutatja a felületek fertőtlenítése között; a \# a szignifikáns különbséget mutatja a különböző kezelések összessége között (HC-DPEE - 4,5 pH - 6,0 pH - 8,5 pH) $(p<0,05)$. 
Az eredményeink szintén igazolták azt az alap megfigyelést, miszerint a Gramnegatív baktériumok ellenállóbbak, mint a Gram-pozitív baktériumok (Burt, 2004; Lebert és mtsi., 2007; Nazzaro és mtsi., 2013, Oussalah és mtsi., 2007). A két Gram-negatív baktérium nagyobb arányban volt jelen a biofilmben, mint a két Gram-pozitív izolátum. Lebert és munkatársai (2007) más eredményt kaptak, az 1 és 2\% tartalmú Satureja thymbra illóolajjal történő 1 órás kezelés hatására a Gram-negatív baktériumok (Pseudomonas fragi és $E$. coli) elpusztultak a vegyes biofilmben, míg a Gram-pozitív baktériumok túléltek $(S$. aureus és L. monocytogenes). Ennek a különbségnek a hátterében az illóolajok különböző összetétele és a baktériumok eltérő érzékenysége ezekre az összetevőkre, állhat. A Satureja thymbra fö összetevője a fenolos típusú karvakrol; ez az összetevő egyáltalán nem volt jelen az általunk vizsgált illóolajokban.

A kísérletünk során alkalmazott ipari fertőtlenítőszer is sikeresen eltávolította a biofilmet a fém és műanyag felületről, de a csempéről és fáról már nem tudta.

Ezen eredmények alapján a 24 órás biofilm esetén a kakukkfüolajos savas fertőtlenítőszer hatott jobban, míg a 168 órás mátrix esetén pedig a fahéjolaj alapú fertőtlenítőszer. Jelen kutatás alapján kimondható, hogy a savas pH-jú $(4,5 \mathrm{pH})$ illóolajos alternatív fertőtlenítőszerek hatásosabbnak bizonyultak a vegyes biofilm ellen, mint egy jelenleg is használt élelmiszeripari fertőtlenítő. Ezek alapján lehetségesnek tartjuk egy illóolaj(ok)on alapuló természetbarát fertőtlenítőszer kifejlesztését.

\subsection{A fertőtlenítőszer optimalizálása}

A Box-Behnken kísérlettervezés során a program által generált kísérletek elvégzése történt meg, mely adatokból és diagramokról leolvashatóak voltak az optimalizált paraméterek. A megbízhatóság eredményeit az E. coli és a L. monocytogenes általános modell organizmusok esetén műanyag felületen a 25 . táblázat tartalmazza és a kapott értékek alapján a modellek használhatóak voltak optimalizálásra. 
25. táblázat. Az optimalizálási kísérlet megbízhatósági eredményei ( $\mathrm{p}$ érték, illeszkedés, zavaró tényezők) és az illeszthető matematikai modell fahéj-, kakukkfü- és majoránna illóolaj esetén polipropilén felületen kialakult biofilmek ellen.

\begin{tabular}{llllll}
\hline Baktérium & Illóolaj & $\mathrm{p}$ value & $\mathrm{R}^{2^{*}}$ & $\mathrm{ap}^{* *}$ & Modell \\
\hline E. coli & kakukkfü & 0,0028 & 0,93 & 10,46 & négyzetes \\
& majoránna & 0,0083 & 0,90 & 7,97 & négyzetes \\
& fahéj & 0,0041 & 0,94 & 12,37 & négyzetes \\
\hline L. monocytogenes & kakukkfü & 0,0341 & 0,84 & 6,22 & négyzetes \\
& majoránna & 0,0016 & 0,95 & 13,44 & négyzetes \\
& fahéj & 0,0027 & 0,65 & 9,57 & lineáris \\
\hline
\end{tabular}

$* \mathrm{R}^{2}$ : determinációs együttható, **ap: jel-zaj arány.

A program által generált változók kombinációja alapján elvégzett kísérletek paramétereit és az elért eredményeket a 26. táblázat foglalja össze. A 8.-9. ábrán a kísérlettervezés során elvégzett kísérletek eredményei láthatóak grafikusan, melyekről leolvashatók az optimális paraméterek. Az ábrákon a piros pontok (design point) az egyes paraméterek szélső és a középértékeit jelzik, melyek egy-egy kísérletre összeadva 17 részkísérletböl álltak, egyes pontok több mérést is rejtenek magukban.

Az eredményeket összegezve megállapíthatjuk, hogy az illóolajok egyszeres MBC koncentrációban alkalmazva nem voltak hatásosak a 24 órás biofilmeken, mivel túl hosszú a fertőtlenítési idő ipari használatra (8.-9. ábra). Az ábrákon jól látható, hogy az E. coli esetén a savas, míg L. monocytogenes esetén a savas és a semlegeshez közeli pH-n érhető el teljes sejtpusztulás (sötétkék terület). Fahéj illóolaj esetén nem kaptunk optimális paramétereket (a legmagasabb koncentráció esetén sem volt teljes biofilm eliminálás) $L$. monocytogenes esetén.

Minden esetben a 10 perces hatóidöhöz tartozó paramétereket határoztuk meg a fertőtlenítéshez, ahol már nem volt élő sejtszám a felületeken (sötétkék rész a 8.-13. ábrákon). Az optimális koncentrációk illóolajonként és baktériumonként változtak, de egyik esetben sem haladta meg a $16 \mathrm{mg} / \mathrm{ml}-\mathrm{t}$. Ezek a következők voltak:

E. coli: fahéjolaj - 1,2 mg/ml, 4,5 és 7,5 pH-nál is; majoránnaolaj - 4,5 mg/ml, pH 4,5-nél; L. monocytogenes: majoránnaolaj - 14,5 mg/ml 4,5 pH-nál, 14,0 mg/ml 6,0 pH-nál és 13,5 mg/ml 7,5 pH-nál. 
26. táblázat. Box-Behnken modell mátrix a független változók szintjeivel és a hozzájuk tartozó eredmények polipropilén felületen 24 órás biofilm esetén.

\begin{tabular}{|c|c|c|c|c|c|c|}
\hline \multicolumn{2}{|c|}{ A / koncentráció (mg/ml) } & \multirow{2}{*}{$\begin{array}{l}\text { B / idő } \\
\text { (min) }\end{array}$} & \multirow{2}{*}{$\begin{array}{l}\mathrm{C} / \\
(\mathrm{pH})\end{array}$} & \multicolumn{3}{|c|}{ Sejtszám $\left(\log _{10} \mathrm{CFU} / \mathrm{cm}^{2}\right)$} \\
\hline $\begin{array}{l}\text { Kakukkfüolaj, } \\
\text { majoránnaolaj }\end{array}$ & Fahéjolaj & & & Kakukkfüolaj & Majoránnaolaj & Fahéjolaj \\
\hline \multirow{4}{*}{6,3} & 1,6 & 10 & 6,0 & 4,08 & 4,20 & 4,43 \\
\hline & & 60 & 4,5 & 3,00 & 4,15 & 4,36 \\
\hline & & 60 & 7,5 & 2,90 & 3,95 & 4,30 \\
\hline & & 110 & 6,0 & 3,48 & 3,70 & 3,85 \\
\hline \multirow[t]{9}{*}{12,5} & 3,2 & 10 & 4,5 & 3,30 & ND & 3,38 \\
\hline & & 10 & 7,5 & 3,00 & ND & 4,30 \\
\hline & & 60 & 6,0 & 3,95 & ND & 4,15 \\
\hline & & 60 & 6,0 & 3,70 & ND & 4,18 \\
\hline & & 60 & 6,0 & 3,78 & ND & 4,04 \\
\hline & & 60 & 6,0 & 3,90 & ND & 4,18 \\
\hline & & 60 & 6,0 & 3,95 & ND & 4,26 \\
\hline & & 110 & 4,5 & ND & ND & 4,32 \\
\hline & & 110 & 7,5 & ND & ND & 4,08 \\
\hline \multirow[t]{4}{*}{18,9} & 4,8 & 10 & 6,0 & ND & ND & 4,23 \\
\hline & & 60 & 4,5 & ND & ND & 4,00 \\
\hline & & 60 & 7,5 & ND & ND & 3,90 \\
\hline & & 110 & 6,0 & ND & ND & 3,78 \\
\hline \multicolumn{7}{|l|}{ E. coli } \\
\hline \multirow[t]{4}{*}{1,6} & 0,4 & 10 & 6,0 & 3,95 & 4,26 & 4,15 \\
\hline & & 60 & 4,5 & ND & ND & 3,90 \\
\hline & & 60 & 7,5 & 3,85 & 4,00 & 3,70 \\
\hline & & 110 & 6,0 & ND & 3,78 & 3,95 \\
\hline \multirow[t]{9}{*}{3,2} & 0,8 & 10 & 4,5 & ND & 2,48 & 3,48 \\
\hline & & 10 & 7,5 & 3,70 & 4,04 & 3,36 \\
\hline & & 60 & 6,0 & 3,60 & 4,08 & 3,85 \\
\hline & & 60 & 6,0 & 3,70 & 4,00 & 3,70 \\
\hline & & 60 & 6,0 & 4,48 & 4,18 & 3,90 \\
\hline & & 60 & 6,0 & 3,60 & 4,08 & 3,85 \\
\hline & & 60 & 6,0 & 3,70 & 4,04 & 3,78 \\
\hline & & 110 & 4,5 & ND & ND & ND \\
\hline & & 110 & 7,5 & ND & 3,60 & 3,15 \\
\hline \multirow[t]{4}{*}{4,8} & 1,2 & 10 & 6,0 & 3,48 & 3,95 & 3,48 \\
\hline & & 60 & 4,5 & ND & ND & ND \\
\hline & & 60 & 7,5 & ND & 3,78 & ND \\
\hline & & 110 & 6,0 & ND & ND & ND \\
\hline
\end{tabular}

ND: nem mutatható ki élösejt a felületen. 

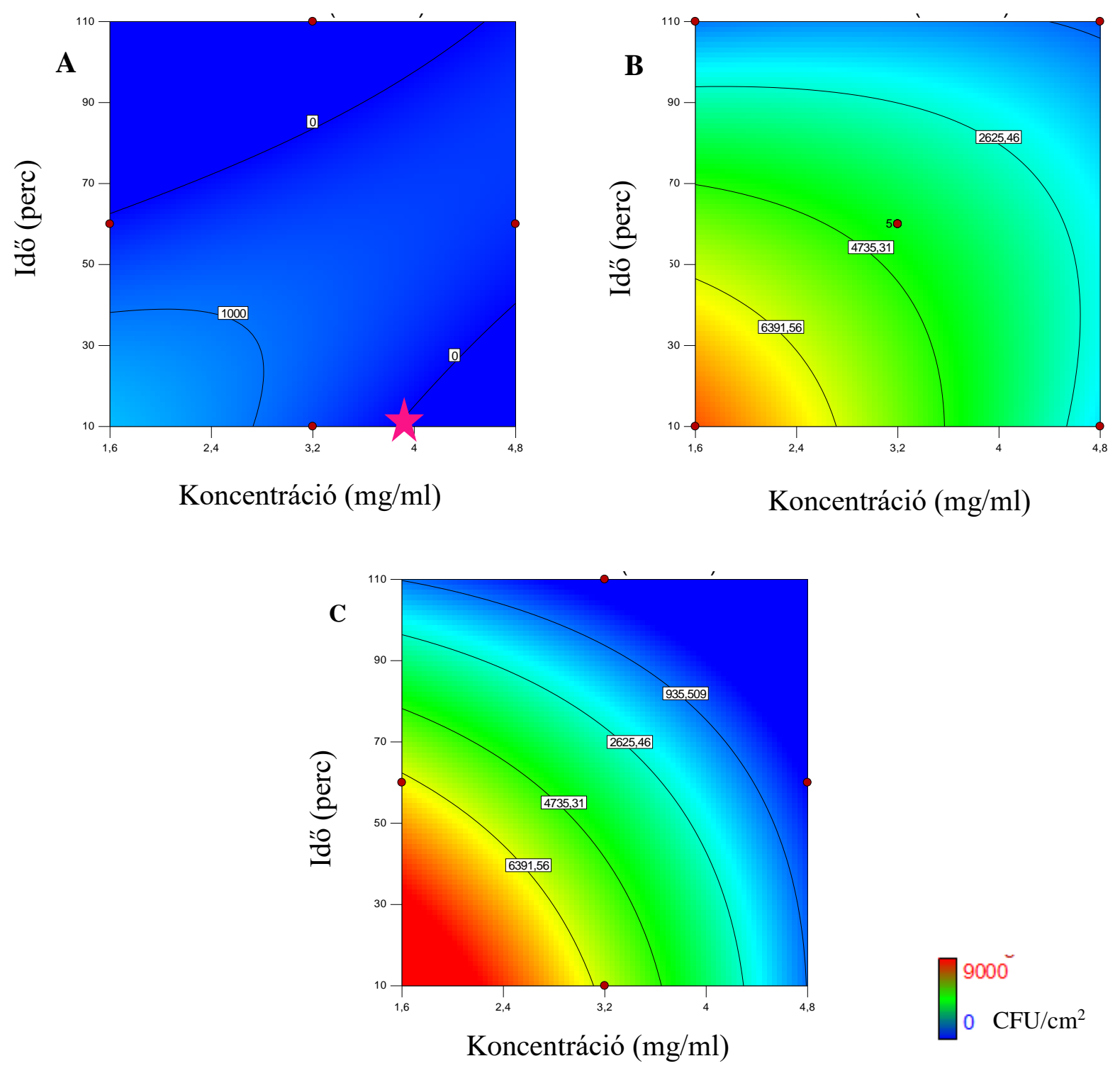

8. ábra. E. coli biofilm túlélő sejtszámának változása $\left(\mathrm{CFU} / \mathrm{cm}^{2}\right)$ polipropilén felületen kakukkfü illóolajjal végzett optimalizálási kísérletekben különböző pH értékeken (A: $\mathrm{pH}$ 4,5; B: pH 6,0; C: pH 7,5). A rózsaszín csillag a fertőtlenítéshez megállapított optimális koncentrációt jelzi $(3,5 \mathrm{mg} / \mathrm{ml})$. 

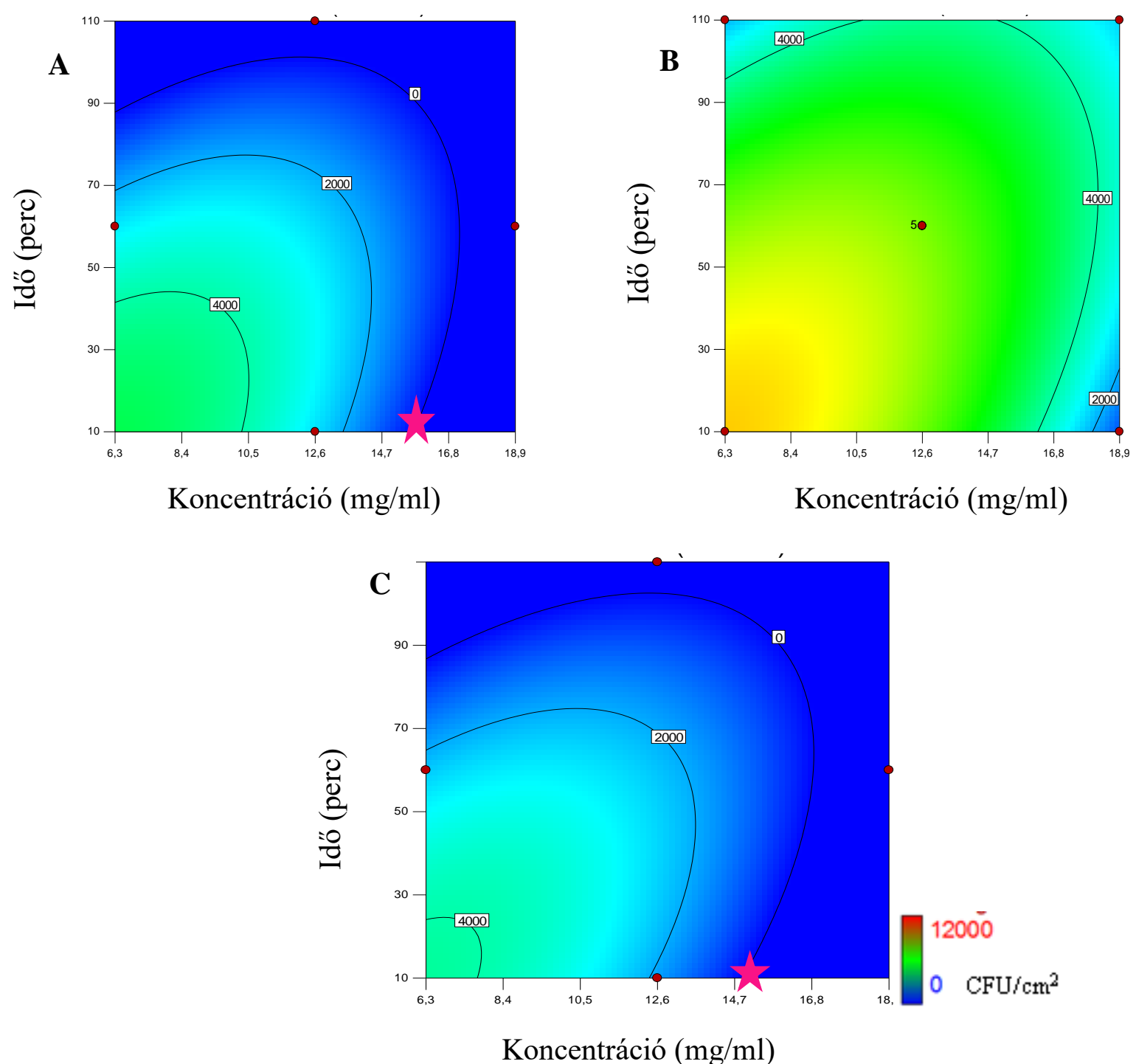

9. ábra. L. monocytogenes biofilm túlélő sejtszámának változása $\left(\mathrm{CFU} / \mathrm{cm}^{2}\right)$ polipropilén felületen a kakukkfü illóolajjal végzett optimalizálási kísérletekben különböző $\mathrm{pH}$ értékeken (A: pH 4,5; B: pH 6,0; C: pH 7,5). A rózsaszín csillag a fertőtlenítéshez megállapított optimális koncentrációt jelzi. (pH 4,5: $18 \mathrm{mg} / \mathrm{ml} ; \mathrm{pH}$ 7,5:15 mg/ml).

Vegyes tenyészet esetén müanyag felületen már 10 perc is elég volt $12,5 \mathrm{mg} / \mathrm{ml}$ koncentrációjú és 4,5-ös pH-jú majoránnaolajos oldattal történő fertőtlenítéshez, míg fafelület esetén $60 \mathrm{mg} / \mathrm{ml}$ koncentrációjú, $\mathrm{pH}$ 4,5-es majoránnaolajos oldat kellett a fertőtlenítéshez 15 perces hatóidővel. Mindkét esetben az eredmények szignifikánsak voltak $(\mathrm{p}<0,05)$, az elörejelzés paraméterei is az elfogadhatósági határon és/vagy felett voltak (27. táblázat). A fahéjolaj esetén is megfelelő volt az optimalizálás, a kakukkfüolaj $\mathrm{p}$ értéke müanyag felületen 0,05 felett volt, ennek ellenére elvégeztük a kísérleteket. A kakukkfüolajjal kapott eredmények a 28. táblázatban azt mutatták, hogy hatásos volt az illóolaj. Az eredményekből látszik, hogy már a 12,5 mg/ml koncentrációjú, 4,5pH-jú 
oldatnak is hatnia kellett 10 perc alatt, így ezzel a kombinációval dolgoztunk a továbbiakban kakukkfüolaj esetén.

27. táblázat. Az optimalizálási kísérlet megbízhatósági eredményei (szignifikancia, illeszkedés, zavaró tényezők) és az illeszthető matematikai modell fahéj-, kakukkfü- és majoránna illóolaj esetén PP és fa felületen kialakult vegyes biofilm fertőtlenítésére.

\begin{tabular}{llcccc}
\hline Felület & Illóolaj & Szignifikancia & Jel-zaj arány & $\mathrm{R}^{2}$ & Modell \\
\hline \multirow{2}{*}{ Mủanyag } & kakukkfü & $>0,05$ & - & - & - \\
& majoránna & 0,024 & 6,4 & 0,91 & négyzetes \\
& fahéj & 0,002 & 18,1 & 0,97 & négyzetes \\
\hline $\mathrm{Fa}$ & kakukkfü & 0,003 & 11,9 & 0,75 & lineáris \\
& majoránna & 0,011 & 9,3 & 0,90 & négyzetes \\
& fahéj & 0,003 & 17,8 & 0,96 & négyzetes \\
\hline
\end{tabular}

28. táblázat. Box-Behnken modell mátrix a független változók szintjeivel és a hozzájuk tartozó eredmények 24 órás vegyes biofilm és PP felület esetén.

\begin{tabular}{|c|c|c|c|c|c|c|c|c|c|}
\hline \multicolumn{2}{|c|}{$\begin{array}{l}\text { A / koncentráció } \\
(\mathrm{mg} / \mathrm{ml})\end{array}$} & \multirow{3}{*}{$\begin{array}{l}\text { B / } \\
\text { idő } \\
\text { (min) }\end{array}$} & \multirow[t]{3}{*}{$\begin{array}{l}\mathrm{C} / \\
\mathrm{pH}\end{array}$} & \multicolumn{6}{|c|}{ Sejtszám $\left(\log _{10} \mathrm{CFU} / \mathrm{cm}^{2}\right)$} \\
\hline \multirow{2}{*}{$\begin{array}{l}\text { Kakukkfüolaj, } \\
\text { majoránnaolaj }\end{array}$} & \multirow{2}{*}{ Fahéjolaj } & & & \multicolumn{2}{|c|}{ Kakukkfüolaj } & \multicolumn{2}{|c|}{ Majoránnaolaj } & \multicolumn{2}{|c|}{ Fahéjolaj } \\
\hline & & & & $\mathrm{Fa}$ & Polipropilén & $\mathrm{Fa}$ & Polipropilén & $\mathrm{Fa}$ & Polipropilén \\
\hline \multirow[t]{4}{*}{12,5} & 1,6 & 10 & 6,0 & 5,23 & 3,60 & 5,11 & 4,00 & 4,95 & 4,23 \\
\hline & & 20 & 4,5 & 4,18 & ND & 4,60 & ND & 4,08 & 3,95 \\
\hline & & 20 & 7,5 & 4,26 & ND & 4,90 & 3,78 & 4,15 & 4,11 \\
\hline & & 30 & 6,0 & 4,20 & ND & 4,95 & 3,95 & 4,18 & 4,08 \\
\hline \multirow[t]{9}{*}{56,3} & 7,2 & 10 & 4,5 & 4,15 & ND & 3,70 & ND & 3,78 & 3,65 \\
\hline & & 10 & 7,5 & 4,20 & ND & 4,97 & 4,04 & 3,95 & 4,08 \\
\hline & & 20 & 6,0 & 4,08 & ND & 4,15 & 4,00 & 4,00 & 4,00 \\
\hline & & 20 & 6,0 & 4,11 & ND & 4,11 & 3,95 & 4,11 & 3,95 \\
\hline & & 20 & 6,0 & 4,20 & ND & 4,26 & 3,97 & 4,15 & 3,92 \\
\hline & & 20 & 6,0 & 4,08 & ND & 4,20 & 3,92 & 4,15 & 4,03 \\
\hline & & 20 & 6,0 & 4,04 & ND & 4,32 & 4,04 & 4,08 & 3,97 \\
\hline & & 30 & 4,5 & 3,95 & ND & ND & ND & 3,48 & ND \\
\hline & & 30 & 7,5 & 4,00 & ND & 4,85 & 3,91 & 3,70 & 3,90 \\
\hline \multirow[t]{4}{*}{100} & 12,5 & 10 & 6,0 & 4,15 & ND & 4,28 & ND & 3,90 & 3,95 \\
\hline & & 20 & 4,5 & 3,85 & ND & ND & ND & ND & ND \\
\hline & & 20 & 7,5 & 4,00 & ND & 4,32 & ND & 3,78 & 3,78 \\
\hline & & 30 & 6,0 & 4,04 & ND & ND & ND & 3,90 & 3,90 \\
\hline
\end{tabular}

ND: nem mutatható ki élősejt a felületen.

A 10.-13. ábrák jól szemléltetik, hogy minél alacsonyabb pH-jú a fertőtlenítőszer, annál hatásosabb volt. A fa és mủanyag felület fertőtlenítése során alkalmazandó 
természetes fertőtlenítőszer koncentráció között majdnem ötszörös különbség volt majoránna illóolaj esetén (10.-11. ábra).

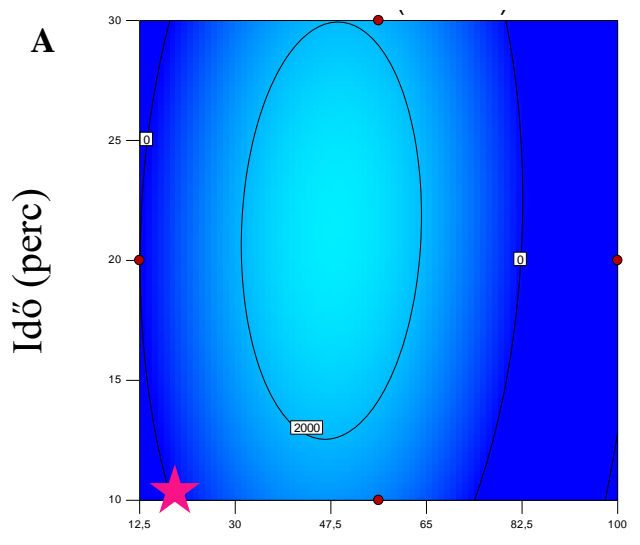

Koncentráció $(\mathrm{mg} / \mathrm{ml})$

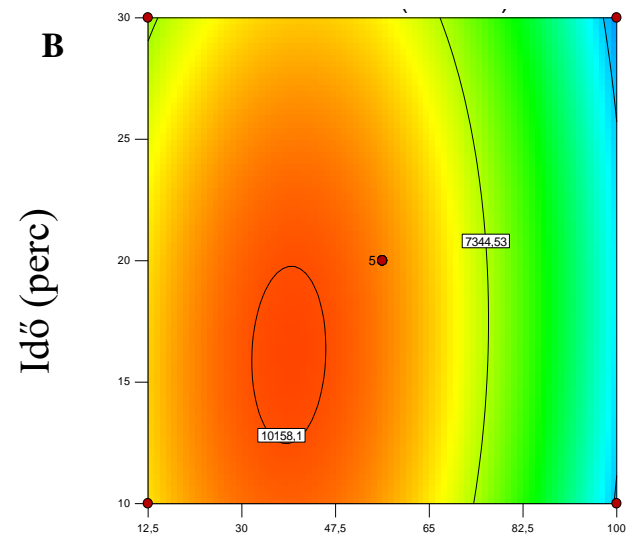

Koncentráció $(\mathrm{mg} / \mathrm{ml})$

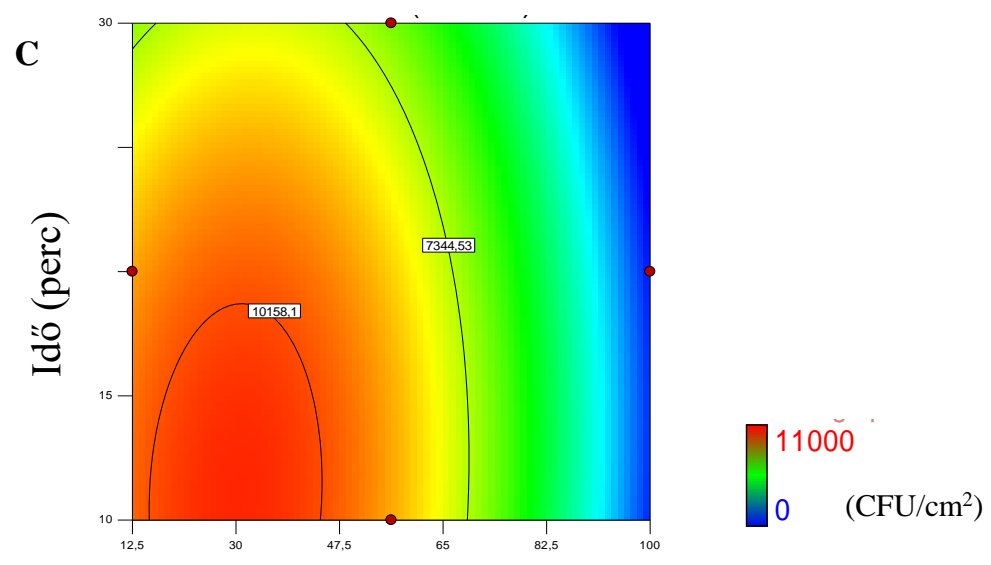

Koncentráció $(\mathrm{mg} / \mathrm{ml})$

10. ábra. Majoránna illóolaj hatása a 24 órás vegyes biofilmen PP felületen különböző pHjú oldatok esetén (A: pH 4,5; B: pH 6,0; C: pH: 7,5). A rózsaszín csillag a fertőtlenítéshez megállapított optimális koncentrációt jelzi $(12,5 \mathrm{mg} / \mathrm{ml} ; 4,5$ pH-nál). 


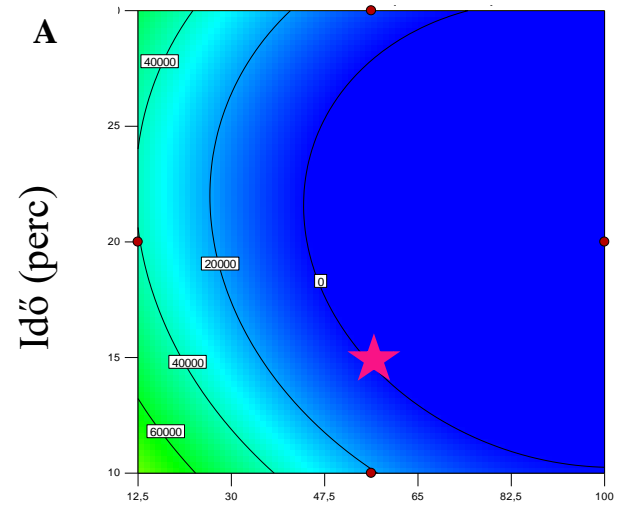

Koncentráció $(\mathrm{mg} / \mathrm{ml})$

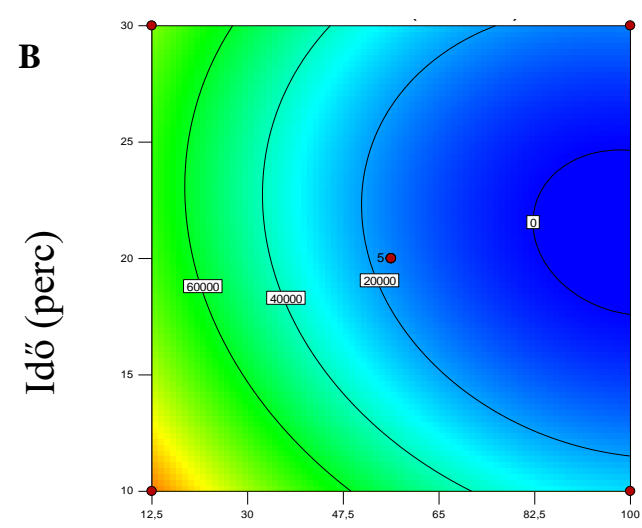

Koncentráció (mg/ml)

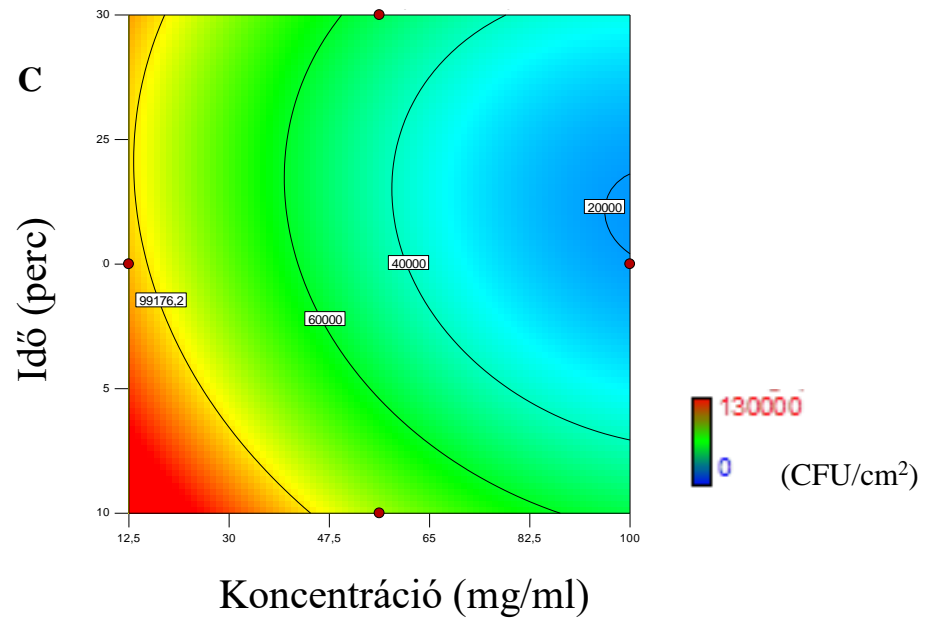

11. ábra. Majoránna illóolaj hatása a 24 órás vegyes biofilmen fafelületen különböző pHjú oldatok esetén (A: $\mathrm{pH} 4,5 ; \mathrm{B}: \mathrm{pH}$ 6,0; C: pH: 7,5). A rózsaszín csillag a fertötlenítéshez megállapított optimális időt és koncentrációt jelzi $(4,5 \mathrm{pH} ; 60 \mathrm{mg} / \mathrm{ml} ; 15 \mathrm{~min})$. 
A kakukkfüolajos oldat esetén az optimalizálás során fa felületre nem tudtunk megállapítani megfelelő fertőtlenítőszert, mivel az optimális koncentráció nagyobb lett volna, mint $100 \mathrm{mg} / \mathrm{ml}$ (12. ábra), mely gazdasági oldalról nézve nem költséghatékony.

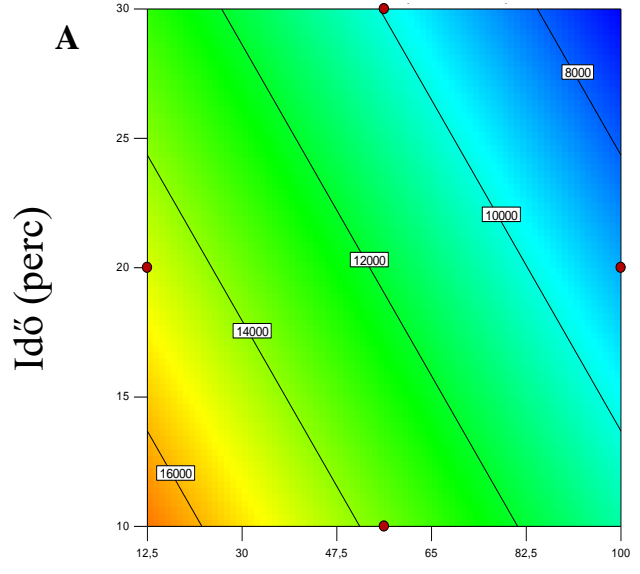

Koncentráció $(\mathrm{mg} / \mathrm{ml})$

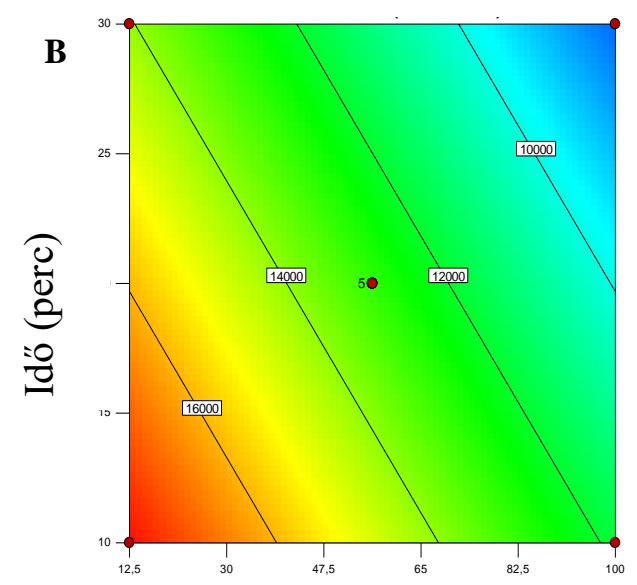

Koncentráció $(\mathrm{mg} / \mathrm{ml})$

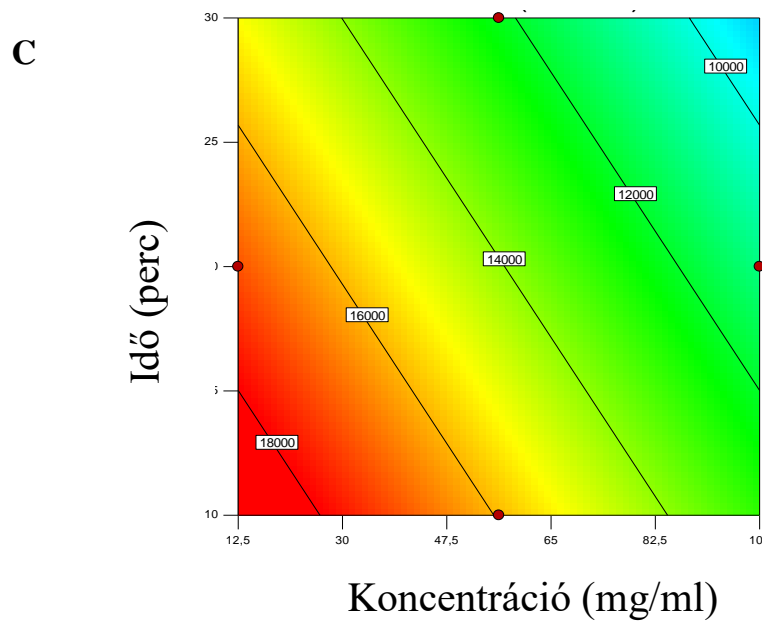

12. ábra. Kakukkfü illóolaj hatása a 24 órás vegyes biofilmen fafelületen különböző pH-jú oldatok esetén (A: $\mathrm{pH} 4,5, \mathrm{~B}: \mathrm{pH}$ 6,0; $\mathrm{C}: \mathrm{pH}: 7,5)$.

A fahéj illóolaj esetén fa és műanyag felületen is tudtuk optimalizálni az illóolajos fertőtlenítőszer paramétereit $12,5 \mathrm{mg} / \mathrm{ml}$, a $\mathrm{pH} 4,5$ volt, 28 perc kellett a fa felület fertőtlenítéséhez, míg 19 perc kellett a polipropilénhez (13. ábra).

A kísérlettervezés során kapott fertőtlenítési paramétereket (pH, idő, koncentráció) ellenőriztük 24 és 168 órás biofilmek fertőtlenítése során mind a 4 fajta felületen, ahol az illóolajos fertőtlenítőszerek sikeresen eltávolították a biofilmeket, kivétel a fa felületről, ahol 95-98\%-os hatást eredményeztek. Az összehasonlításként használt Brandolin felületi fertőtlenítő csak 40-61\%-os és a HC-DPE 55-87\%-os hatással rendelkezett. Ezek alapján 
az illóolaj alapú fertőtlenítőszer jó alternatívaként alkalmazható lehetne ipari használatra is.

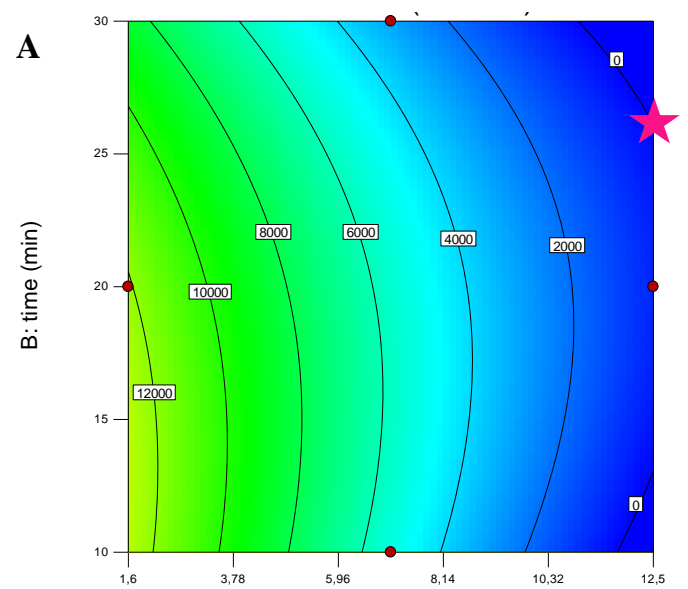

Koncentráció $(\mathrm{mg} / \mathrm{ml})$

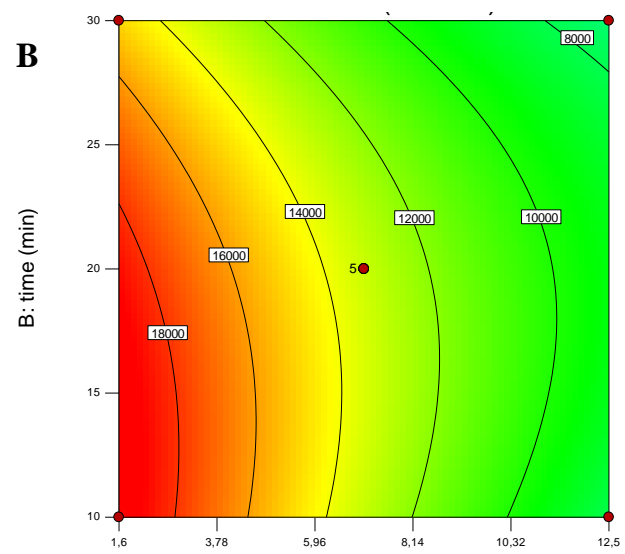

Koncentráció $(\mathrm{mg} / \mathrm{ml})$

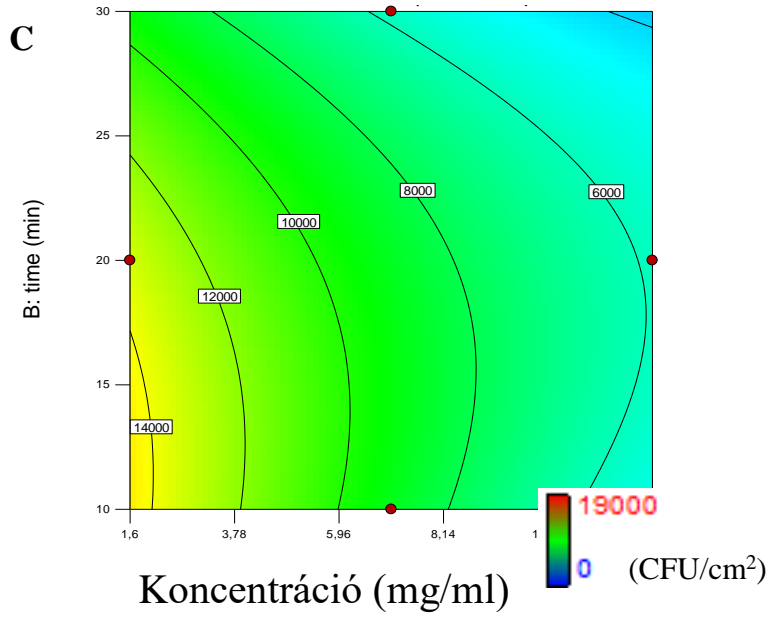

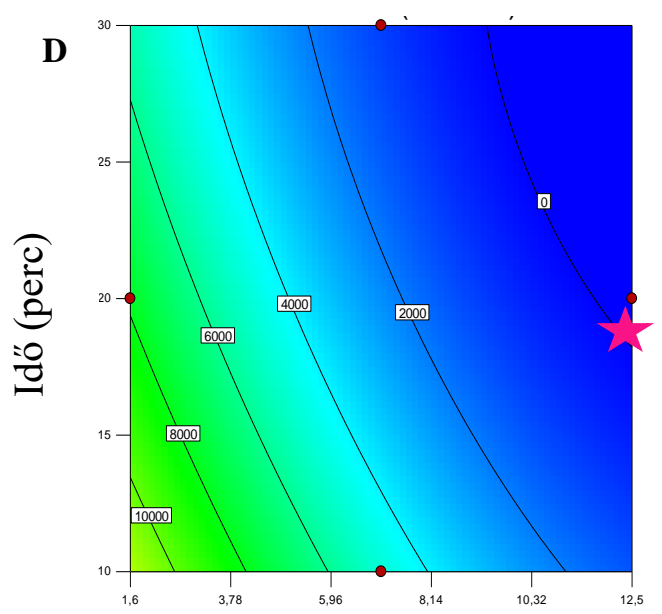

Koncentráció $(\mathrm{mg} / \mathrm{ml})$

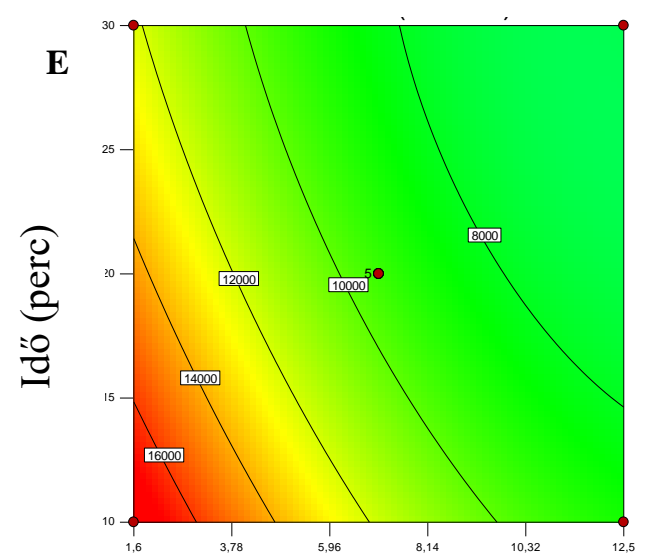

Koncentráció $(\mathrm{mg} / \mathrm{ml})$

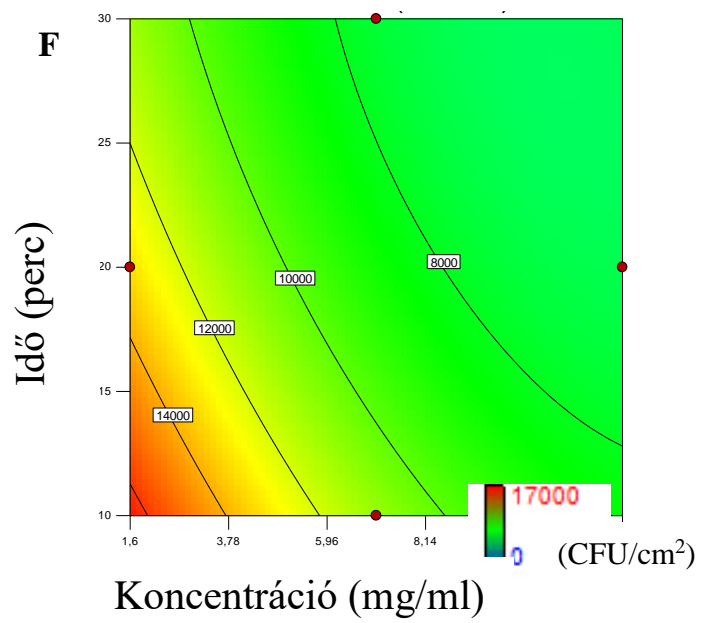

13. ábra. Fahéj illóolaj hatása a 24 órás vegyes biofilmen fa $(\mathrm{A}, \mathrm{B}, \mathrm{C})$ és $\mathrm{PP}(\mathrm{D}, \mathrm{E}, \mathrm{F})$ felületen különböző pH-jú oldatok esetén (A, D: pH 4,5, B, E: pH 6,0; C, F: pH: 7,5). A rózsaszín csillag a fertőtlenítéshez megállapított optimális időt és koncentrációt jelzi. 


\subsection{Elekronmikroszkópos felvételek}

Az elektronmikroszkópos felvételekkel is jól lehetett bizonyítani az illóolajok fertőtlenítő hatását mủanyag felületeken kialakult biofilmeken. A 14. ábrán az látható, hogy a műanyag felületen a kakukkfüolajos fertőtlenítés után eltűnt a 24, illetve 168 órás L. monocytogenes biofilm.
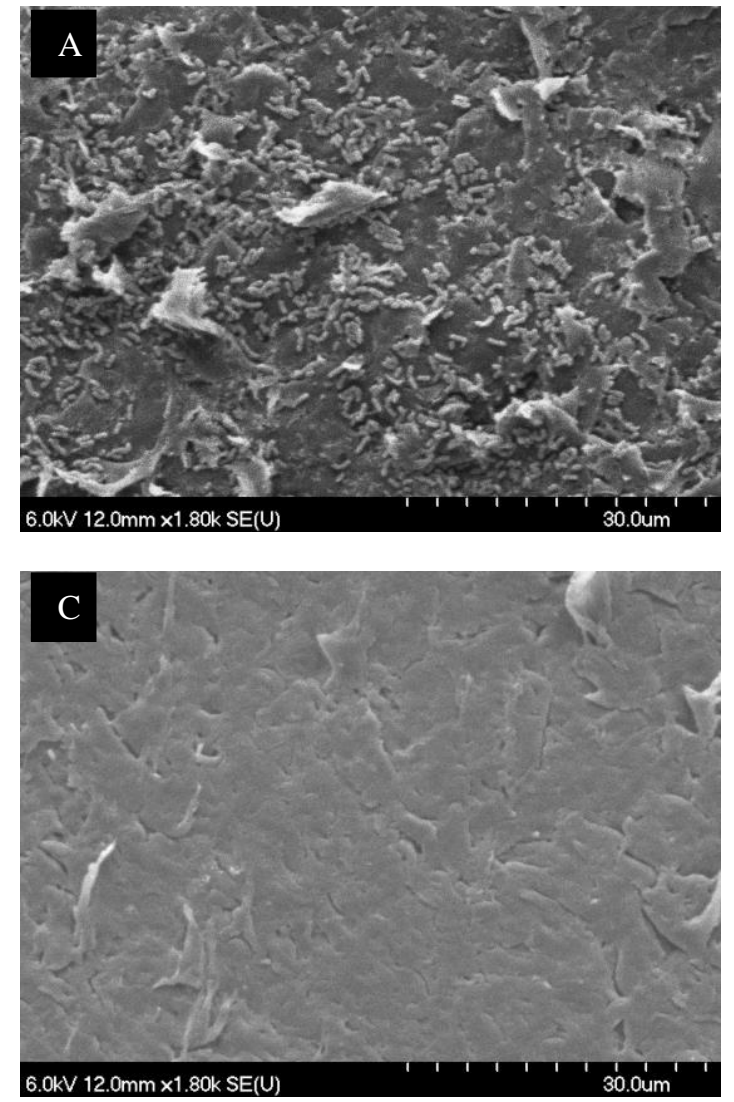
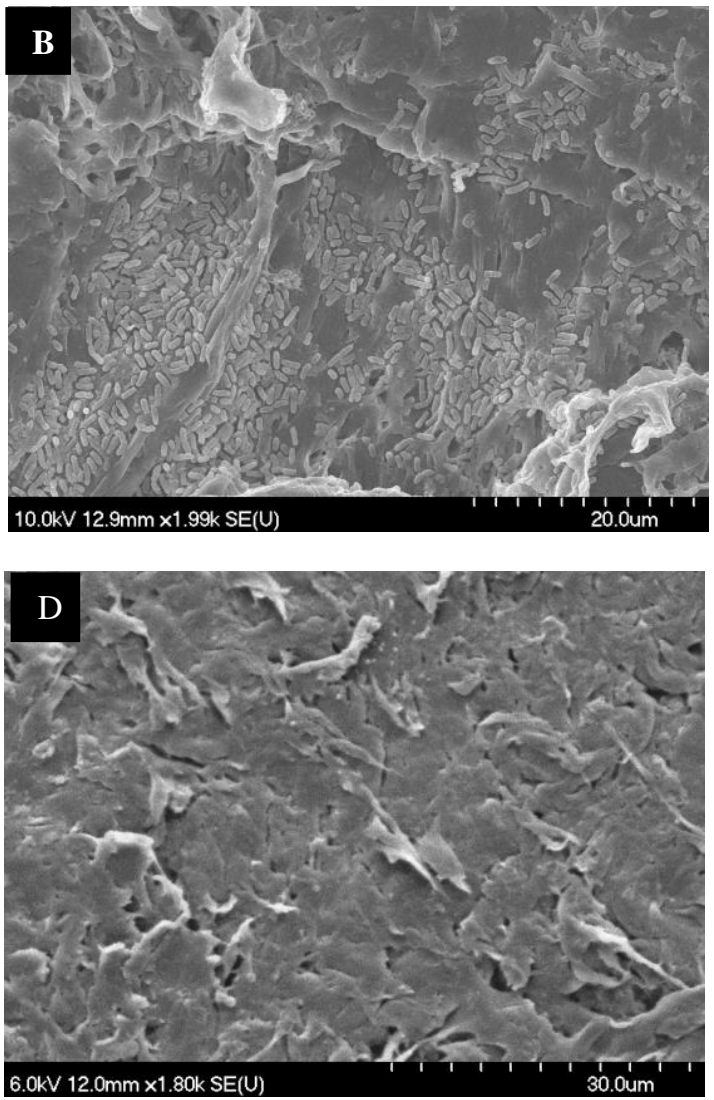

14. ábra. Pásztázó elektonmikroszkópos felvételek $24(\mathrm{~A}, \mathrm{C})$ és 168 órás $(\mathrm{B}, \mathrm{D}) L$. monocytogenes polipropilénen kialakult biofilmekről kakukkfüolajos fertőtlenítés előtt (A, B) és után $(C, D)$.

A 15. ábrán majoránna illóolaj hatása látható E. coli sejtekre. Néhány helyen már csak a felgyürődött, üres sejtfal látható, de az ép sejtek sem mutatnak szabályos sejtalakot. Némelyik hosszabb az átlagnál, a sejtfal láthatóan nem ép, néhol hiányos. 


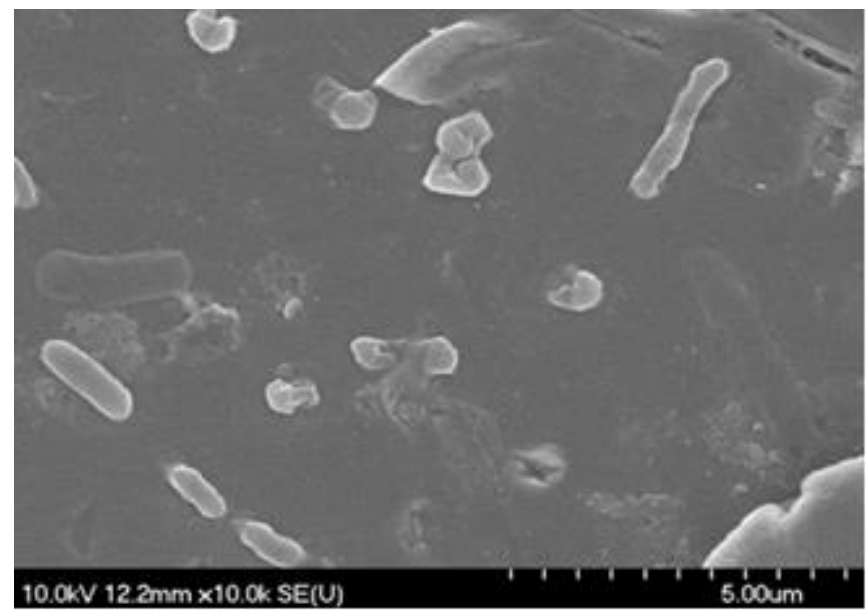

15. ábra. Pásztázó elektonmikroszkópos felvétel E. coli sejtekről majoránna illóolajos kezelés után.

A 16. ábra jól szemlélteti mind a 3 illóolaj hatását a vegyes biofilmeken. Az A és D képen látszik a termelt EPS is. A B és C képeken roncsolt sejtfalú sejtek láthatók, ahol a citoplazma részben vagy egészben kifolyt a sejtből. Ezen képek nagyszerü bizonyítékai az illóolajok sejtpusztító hatásának.
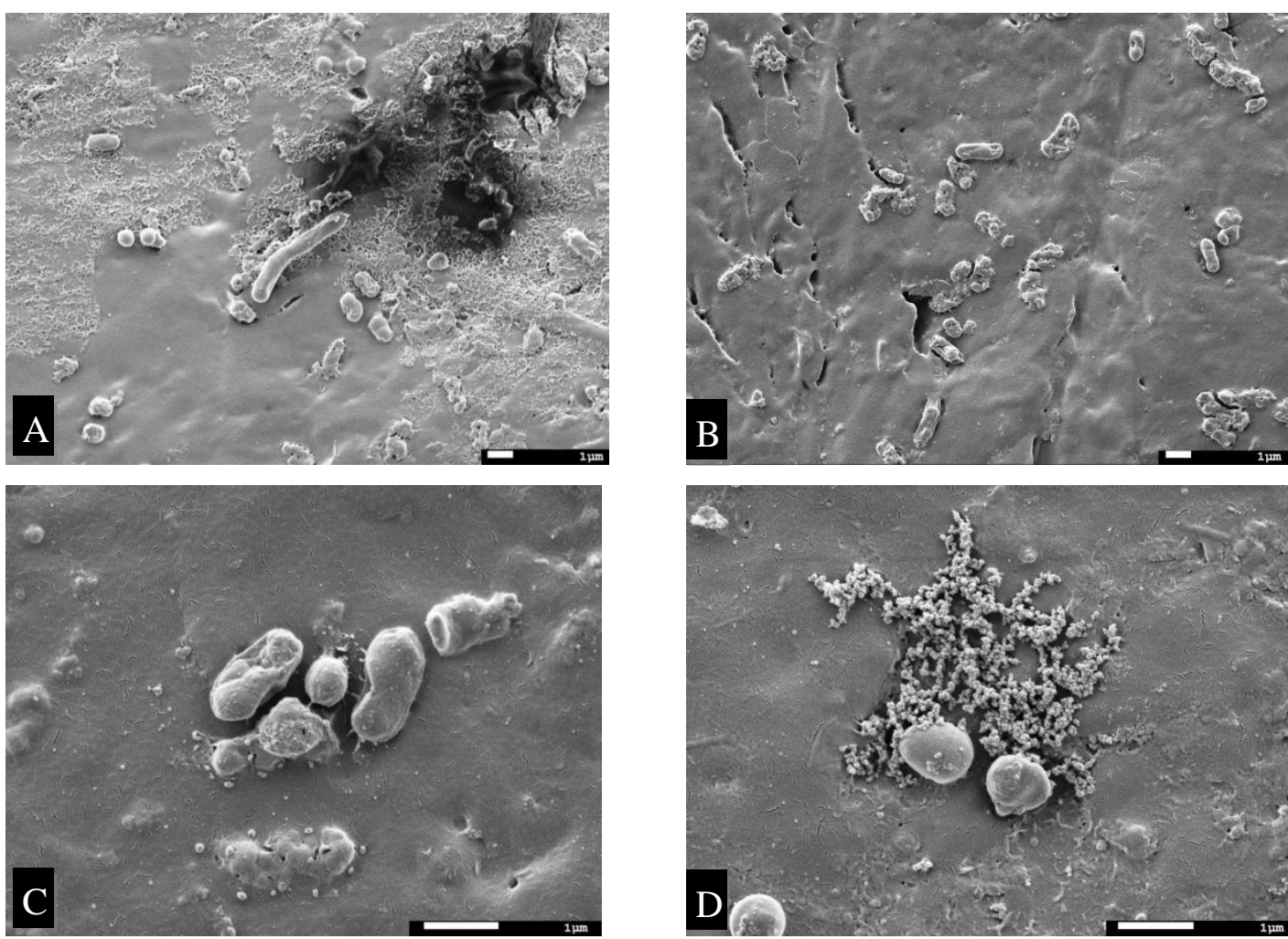

16. ábra. Pásztázó elektonmikroszkópos felvételek 168 órás vegyes biofilmről fertőtlenítés előtt (A) (5000x nagyításban), majoránnaolajos kezelés után (B) (5000x nagyításban), fahéjolajos kezelés után (C) (15000x nagyításban) és kakukkfüolajos fertőtlenítés után (D) (15000x nagyításban). 


\section{7. Összefoglalás}

A bakteriális biofilmek állandó szennyezési forrást jelentenek az élelmiszeriparban, ezért eltávolításuk kiemelkedően fontos. A biofilmekben élő sejtek ellenállóbbak a fertőtlenítőszerekkel szemben, amit a sejtek által kiválasztott, a biofilmet körülvevő extracelluláris polimerekből álló (EPS) réteg is segít. Ez a réteg fizikai és kémiai védelmet is jelenthet; a fertőtlenítőszerek nem tudnak áthatolni rajta, illetve a háromdimenziós biofilm felső rétegében már hatásukat vesztik, így a mélyebben fekvő sejtek túlélhetnek. $\mathrm{Az}$ élelmiszeriparban használható fertőtlenítőszerek száma élelmiszerbiztonsági meggondolások miatt korlátozott, ezért szükség lehet új, alternatív megoldásokra. A növényi hatóanyagokon alapuló szerek nagy előnye, hogy természetes anyagok, így felhasználásuk elnyerheti a fogyasztók tetszését is.

Kutatásunk fő célja olyan természetes, illóolaj alapú fertőtlenítőszerek kifejlesztése volt, melyek hatékonyan képesek eltávolítani a bakteriális biofilmeket különbözö, az élelmiszeriparban használatos felületekröl.

1/ Vizsgálataink során a boróka-, citrom-, fahéj-, kakukkfü-, majoránna- és muskotályzsálya illóolaj hatását vizsgáltuk élelmiszerszennyező baktériumokon ( $E$. coli, $P$. putida) és élelmiszer eredetü kórokozókon (B. cereus, B. subtilis, L. monocytogenes, $S$. aureus). Vizsgáltunk még egy vegyes tenyészetet is, amit az E. coli, P. putida, L. monocytogenes, S. aureus egy-egy arányú keverésével hoztunk létre, valamint a klinikai jelentőségü methicillin rezisztens $S$. aureus-t (MRSA) is. A törzsgyüjteményből származó baktériumok mellett bevontuk a vizsgálatba az általunk élelmiszeriparból izolált és nemzetség szintig meghatározott baktériumokat is. Az izolátumok a Citrobacter, Enterobacter, Escherichia, Pseudomonas és Serratia nemzetségbe tartoztak.

A vizsgált illóolajok közül a boróka-, citrom- és muskotályzsálya-olaj a legtöbb baktériumon hatástalannak bizonyult vagy $100 \mathrm{mg} / \mathrm{ml}$ feletti MIC értékkel rendelkezett, így ezeket az illóolajokat kihagytuk a további vizsgálatokból. Összességében a Gramnegatív baktériumok, illetve az élelmiszeriparból izolált baktérium törzsek ellenállóbbnak bizonyultak az illóolajokkal szemben. Vegyes populáció esetén a populáció egészére vonatkozó MBC érték megegyezett a legellenállóbb baktériumhoz tartozó MBC értékekkel. Az illóolajok igen hatékonyak voltak az MRSA-val és L. monocytogenes-szel szemben. 
2/ Az illóolajok kölcsönhatásait vizsgálva megállapítottuk, hogy a legjobb eredményeket akkor értük el, ha legalább az egyik illóolaj tartalmazott fenolos jellegü összetevőket, mint amilyen a timol a kakukkfüolajban.

A legtöbb esetben additív vagy szinergista hatást értünk el, kivéve az élelmiszeriparból izolált Enterobacter törzs esetében, ahol az illóolajok rontották egymás hatását, antagonizmus lépett fel. A Gram-negatív baktériumok a keverékekkel szemben is ellenállóbbnak mutatkoztak.

3/ Az illóolajok szubletális koncentrációban szignifikánsan csökkentették a rozsdamentes acélra és polipropilén felületre letapadt baktériumok számát. Egyes esetekben teljes gátlást értünk el, azaz a vizsgált négy óra időtartam alatt a sejtek nem voltak képesek kitapadni.

A felület maga nem befolyásolta a baktériumok tapadási képességét, míg az élelmiszermaradványokkal való szennyezettség nagymértékben elősegítette a baktériumok tapadását, ezáltal rontotta az illóolajok gátló hatását. Elsősorban a fehérje jellegü szennyeződések okozták a gátló hatás csökkenését, mivel ezek képesek az aldehides illóolaj összetevőket, mint a fahéjaldehid, kovalensen kötni. Ha a fehérjéket eltávolítottuk a szennyeződésből, a gátló hatás visszatért. A baktériumok közül itt is az élelmiszeriparból izolált Enterobacter törzs mutatta a legnagyobb ellenállást.

4/ Az illóolajok baktericid kinetikáját az illóolaj koncentráció és a fertőtlenítő oldat pH-jának függvényében vizsgáltuk. Az iparban is alkalmazható rövid pusztulási idő eléréséhez a 24 órás baktericid koncentráció két-háromszoros értékére, illetve az oldat pHjának savas vagy lúgos irányban való eltolására volt szükség.

5/ A baktériumpusztulási kinetika vizsgálatokban megkapott paraméterek (koncentráció, idő, $\mathrm{pH}$ ) felhasználásával megkíséreltük a müanyag és rozsdamentes acél felületeken kialakított éretlen, 24 órás, és érett, 168 órás, biofilmek eltávolítását. A fertőtlenítés jobb hatású volt fém felületen, mint műanyagon. Az érett biofilmek eltávolítása, illetve sejtszám csökkentése könnyebb volt, ami talán a tápanyagforrások kimerülésével és a toxikus anyagok felhalmozódásával is kapcsolatban lehet. A legjobb hatást, azaz a biofilmek teljes megszüntetését majoránna illóolajjal értük el savas pH-án, de a többi illóolaj is savas pH-n mutatta a legjobb hatást. Savas pH-n a legtöbb illóolaj összetevő nem-disszociált állapotban van, illetve erősen hidrofób, ami lehetővé teszi számukra, hogy átjussanak a baktériumok sejthártyáján és zavart okozzanak a normál sejtmüködésben. 
6/ Illóolajok segítségével eltávolítottuk, illetve gyengítettük a négy fajból létrehozott vegyes biofilmet rozsdamentes acél, polipropilén, csempe és fafelületen. Az iparban és a háztartásokban ritkán alakulnak ki egyfajú biofilmek, sokkal jellemzőbbek a vegyes közösségek. A háztartásokban a mikrobiális szennyeződés egyik fő forrása lehet a fa vágódeszka, ezért ezt a felületet is modelleztük a kísérletekben. Itt is a savas $\mathrm{pH}$ bizonyult hatásosabbnak, de a fafelületről nem minden esetben tudtuk eltávolítani a biofilmet.

7/ A Box-Behnken kísérlettervezési módszer segítségével optimalizáltuk az alkalmazni kívánt illóolaj alapú fertőtlenítőszert, amely alkalmas rozsdamentes acél, polipropilén, csempe és fafelületen kialakult, egy- és többfajú biofilmek eltávolítására.

Az általunk ajánlott természetbarát, alternatív antibakteriális oldat majoránna- vagy fahéj illóolaj alapú, savas kémhatású ( $\mathrm{pH}$ 4,5). Figyelembe véve a legnehezebben fertőtleníthető fafelületeket az ajánlott illóolaj koncentráció $60 \mathrm{mg} / \mathrm{ml}$ majoránnaolaj és $12,5 \mathrm{mg} / \mathrm{ml}$ fahéjolaj esetében, ha háztartásokban is kívánják használni a fertőtlenítőszert. A fertőtlenítési idő felülettől függően 10 és 30 perc között változik. 


\section{Summary}

Bacterial biofilms present a continuous source of contamination in food industry, their removal is, hence, of especial importance. Cell living in the biofilms are more resistant to disinfectants which is supported also by a layer of extracellular polymers (EPS), secreted by the cells, surrounding the biofilm. This layer can provide physical and chemical protection; disinfectants cannot penetrate it or lose their activity within the uppermost layer of the three-dimensional biofilm, and so the cells in deeper layers can survive. The number of disinfectant usable in food industry is rather limited due to food safety reasons that is why novel, alternative solutions may be required. Agents based on phytochemicals have the great advantage of being of natural origin, and their use is likely acceptable also for the consumers.

The main aim of our research work was to develop natural disinfectants based on essential oils that can efficiently remove bacterial biofilms from various surfaces used in food industry.

1/ In our studies, the effect of juniper-, lemon-, cinnamon-, thyme-, marjoram-, and clary sage essential oils was examined on food spoilage bacteria (Escherichia coli, Pseudomonas putida), and on pathogens of food origin (Bacillus cereus, Bacillus subtilis, Listeria monocytogenes, Staphylococcus aureus). A mixed culture (E. coli, P. putida, L. monocytogenes and $S$. aureus in equal proportions), and a clinically relevant methicillin resistant S. aureus (MRSA) was also investigated. Beside bacteria from the microbiological collection, bacteria isolated by us from food industrial sources, identified at genus level, were also included in the studies.

The isolates belonged to the genera Citrobacter, Enterobacter, Escherichia, Pseudomonas and Serratia.

From the essential oils investigated, juniper-, lemon- and clary sage oil showed no effect on most of the bacteria or had minimal inhibitory concentration (MIC) over 100 $\mathrm{mg} / \mathrm{mL}$, so these were omitted from further work. Generally, Gram-negative bacteria and imdustrial isolates were more resistant to the essential oils. In case of mixed population, the minimal bactericidal concentration (MBC) of the whole population was equal to that of the most resistant bacterium. Essential oils were very efficient also against MRSA and $L$. monocytogenes. 
2/ By examining the interactions of the essential oils it was found that the best results could be obtained if at least one of the oils had a phenolic component, such as thymol in thyme oil.

In most cases, additive or synergistic effect was achieved, except for the isolated Enterobacter strain in which case the essential oils diminished the effect of each other so that antagonism was observed. Gram-negative bacteria were more resistant also to the mixtures.

3/ In sublethal concentrations, essential oils significantly reduced the number of bacteria attached to stainless steel and polypropylene surfaces. In some cases, complete inhibition was seen, that is, the cells were unable to attach during the four ours of investigation.

The surface itself had no influence on the attaching ability of the bacteria, but contamination with food residues greatly promoted attaching and decreased the effect of essential oils. First of all, proteinous contaminations capable of covalently binding aldehydic components of the oils like cinnamaldehyde, caused decreased inhibitory effect. If proteins were removed from the contaminants, inhibitory effect was restored. Among the bacteria, the isolated Enterobacter sp. was the most resistant also in this experiment.

4/ Bactericidal kinetics of the essential oils was examined in dependence of essential oil concentration and $\mathrm{pH}$ of the disinfectant solution.

To achieve short killing times, suitable for industrial application, two- to threefold of the 24 hours bactericidal concentration was necessary, or the $\mathrm{pH}$ of the solution had to be shifted to more acidic or more alkaline.

5/ Using the parameters obtained by examining the kinetics of bacterium killing (concentration, time, $\mathrm{pH}$ ) we attempted removal of immature (24 hours) and matured (168 hours) biofilms from plastic and stainless steel surfaces.

Disinfection was more efficient on stainless steel than on plastic surface. With aged biofilms, removal or cell count reduction was easier, possibly because of exhaustion of nutrients or accumulation of toxic substances. The best effect, that is, complete elimination of the biofilm, was achieved with marjoram oil at acidic $\mathrm{pH}$ but the other essential oils also showed their best effect in acidic solution. At low $\mathrm{pH}$, most components of the essential oils are in non-dissociated state and strongly hydrophobic, enabling them to cross the bacterial cell membrane and to disturb normal cellular functions.

6/ By means of essential oils, the mixed biofilm created with four species was removed or weakened on stainless steel, polypropylene, tile, and wood surfaces. 
In industry and in households, single species biofilms are rare, mixed communities are much more typical. In households, wooden cutting boards can be a major source of microbial contamination, so this surface was also modelled in our research work. Acidic $\mathrm{pH}$ proved more efficient also here, but we could not remove the biofilm from the wooden surface in every case.

7/ The essential oil-based disinfectant, suitable for removal of single- or multispecies biofilms formed on stainless steel, polypropylene, tile, and wood surfaces, was optimized applying the Box-Behnken experiment design.

The nature-friendly alternative antibacterial solution recommended by us is based on marjoram or cinnamon essential oil and has acidic $\mathrm{pH}$ (4.5). Regarding the hardest to disinfect wooden surfaces, the recommended concentration of essential oil is $60 \mathrm{mg} / \mathrm{mL}$ for marjoram and $12.5 \mathrm{mg} / \mathrm{mL}$ for cinnamon, if the disinfectant is to be applied also in households. Disinfection time is 10 to 30 minutes depending on the surface. 


\section{Irodalomjegyzék}

2073/2005 Európai Közösségi rendelet az élelmiszerek mikrobiológiai kritériumairól.

4/1998. (XI. 11.) Egészségügyi Minisztériumi rendelet az élelmiszerekben előforduló mikrobiológiai szennyeződések megengedhető mértékéről.

Abee, T., Kovács, Á. T., Kuipers, O. P., van der Veen, S. (2011) Biofilm formation and dispersal in Gram-positive bacteria. Cur Opin Biotech. 22, 172-179.

Ádám, É. (2006) Mikrobiológia gyógyszerész- és fogorvostanhallgatóknak. Semmelweis Kiadó, 149-151, 157-158.

Ahn, J., Grün, I. U., Mustapha, A. (2007) Effects of plant extracts on microbial growth, color change, and lipid oxidation in cooked beef. Food Microbiol. 24, 7-14.

Allen, K. J., Walecka-Zacharska, E., Chen, J. C., Kosek-Paszkowska, K., Devlieghere, F., Van Meervenne, E., Osek, J., Wieczorek, K., Bania, J. (2016) Listeria monocytogenes An examination of food chain factors potentially contributing to antimicrobial resistance. Food Microbiol. 54, 178-189.

An, Y. H., Friedman, R. J. (1998) Concise review of mechanisms of bacterial adhesion to biomaterial surfaces. J Biomed Mater Res. 43 (3), 338-348.

Anderson, I., Sorokin, A., Kapatral, V., Reznik, G., Bhattacharya, A., és mtsi. (2005) Comparative genome analysis of Bacillus cereus group genomes with Bacillus subtilis. FEMS Microbiol Let. 250, 175-184.

Ariani, N., Visser, A., Teulings, M. R. I. M., Dijk, M., Rahardjo, T. B. W., Vissink, A., van der Mei, H. C. (2015) Efficacy of cleansing agents in killing microorganisms in mixed species biofilms present on silicone facial prostheses-an in vitro study. Clin Oral Invest. 19, 2285-2293.

Arnold, J. W., Bailey, G. W. (2000) Surface finishes on stainless steel reduce bacterial attachment and early biofilm formation: Scanning electron and atomic force microscopy study. Poultry Sci. 79, 1839-1845.

$\begin{array}{lllll}\text { Aromax boróka illóolaj } & \text { (letöltve: } & 2015 . & 21 .)\end{array}$ http://aromax.hu/hu/termekeink/reszletek/borokaolaj/.

Aromax citrom illóolaj (letöltve: 2015.21.$)$ http://aromax.hu/hu/termekeink/reszletek/citromolaj/.

Aromax fahéj illóolaj (letöltve: 2015.21 .) http://aromax.hu/hu/termekeink/reszletek/fahejolaj/. 
Aromax kakukkfü illóolaj (letöltve: $2015 . \quad 09 . \quad 21$. http://aromax.hu/hu/termekeink/reszletek/kakukkfuolaj/.

Aromax majoránna illóolaj (letölve: 2015. 09. 21.) http://aromax.hu/hu/termekeink/reszletek/majorannaolaj/.

Aromax muskotályzsálya illóolaj (letöltve: 2015. 09.21. ) http://aromax.hu/hu/termekeink/reszletek/muskotalyzsalyaolaj/.

Aviat, F., Gerhards, C., Rodriguez-Jerez, J.-J., Michel, V., Le Bayon, I., Ismail, R., Federighi, M. (2016) Microbial safety of wood in contact with food: a review. Compr Rev Food Sci S. 15, 491-505, DOI: 10.1111/1541-4337.12199.

Bae, Y. M., Baek, S. Y., Lee, S. Y. (2012) Resistance of pathogenic bacteria on the surface of stainless steel depending on attachment form and efficacy of chemical sanitizers. Int J Food Microbiol. 153, 465-473.

Bajpai, V. K., Baek, K.-H. (2016) Biological efficacy and application of essential oils in foods-A review. J Essent Oil Bear P. TEOP 19, 1-19.

Bajpai, V. K., Baek, K. H., Baek S. C. (2012) Control of Salmonella in foods by using essential oils: A review. Food Res Int. 45, 722-734.

Bakkali, F., Averbeck, S., Averbeck, D., Idaomar, M. (2008) Biological effects of essential oils - A review. Food Chem Toxicol. 46, 446-475.

Bassolé, I. H. N, Juliani, H. R. (2012) Essential oils in combinaton and their antimicrobial properties. Molecules 17, 3989-4006.

Bíró, G. (2014) Élelmiszer-higiénia. Agroinform Kiadó.

Bowker, B. C., Zhuang, H. (2013) Relationship between muscle exudate protein composition and broiler breast meat quality. Poultry Sci. 92, 1385-1392.

Burt, S. (2004) Essential oils: their antibacterial properties and potential applications in foods-a review. Int J Food Microbiol. 94, 223-253.

Busatta C., Vidal, R. S., Popiolski, A. S., Mossi, A. J., Dariva, C. és mtsi. (2008) Application of Origanum majorana L. essential oil as an antimicrobial agent in sausage. Food Microbiol. 25, 207-211.

Busscher, H. J., van der Mei, H. C. (2012) How do bacteria know they are on a surface and regulate their response to an adhering state? PLoS Pathog. 8 e1002440, doi:10.1371/journal.ppat.1002440.

Caillet, S., Côté, J., Sylvain, J.-F., Lacroix, M. (2012) Antimicrobial effects of fractions from cranberry products on the growth of seven pathogenic bacteria. Food Control 23, 419-428. 
Calo, J. R., Crandall, P. G., O’Bryan, C. A., Ricke, S. C. (2015) Essential oils as antimicrobials in food systems - A review. Food Control 54, 111-119.

Carpentier, B., Cerf, O. (2011) Review-Persistence of Listeria monocytogenes in food industry equipment and premises. Int J Food Microbiol. 145, 1-8.

Casarin, L.S., Brandelli, A., de Oliveira Casarin, F., Soave, P. A., Wanke, C. H., Tondo, E. C. (2014) Adhesion of Salmonella Enteritidis and Listeria monocytogenes on stainless steel welds. Int J Food Microbiol. 191, 103-108.

Castelani, L., Pilon, L. E., Martins, T., Pozzi, C. R., Arcaro, J. R. P. (2015) Investigation of biofilm production and icaA and icaD genes in Staphylococcus aureus isolated from heifers and cows with mastitis. Anim Sci J. 86, 340-344, doi:10.1111/asj.12284.

Cava, R., Nowak, E., Taboada, A., Marin-Iniesta, F. (2007) Antimicrobial activity of clove and cinnamon essential oils against Listeria monocytogenes in pasteurized milk. J Food Protect. 70 (12), 2757-2763.

Chorianopoulos, N. G., Giaouris, E. D, Skandamis, P. N, Haroutounian, S. A., Nychas, G. J. E. (2008) Disinfectant test against monoculture and mixed-culture biofilms composed of technological, spoilage and pathogenic bacteria: bactericidal effect of essential oil and hydrosol of Satureja thymbra and comparison with standard acid-base sanitizers. $J$ Appl Microbiol. 104, 1586-1596.

da Silva Fernandes, M. S., Kabuki, D. Y., Kuaye, A. Y. (2015) Behavior of Listeria monocytogenes in a multi-species biofilm with Enterococcus faecalis and Enterococcus feacium and control through sanitation procedures. Int J Food Microbiol. 200, 5-12.

Davidson, P. M. Harrison, M. A. (2002) Resistance and adaptation to food antimicrobials, sanitizers, and other process control. Food Techol. 56 (11), 69-78.

de Oliveira, M. M. M., Brugnera, D. F., das Graças Cardoso, M., Alves, E., Piccoli, R. H. (2010) Disinfectant action of Cymbopogon sp. essential oils in different phases of biofilm formation by Listeria monocytogenes on stainless steel surface. Food Control $21(4), 549-553$.

Deák, T., Kiskó, G., Maráz, A., Mohácsiné Farkas Cs. (2006) Élelmiszer-mikrobiológia. Mezőgazda Kiadó.

Desai, M. A., Soni, K. A., Nannapaneni, R., Schilling, M. W., Silva, J. L. (2012) Reduction of Listeria monocytogenes biofilms on stainless steel and polystyrene surfaces by essential oils. J Food Protect. 75, 1332-1337.

Di Bonaventura, G., Piccolomini, R., Paludi, D., D’Orio, V., Vergara, A., Conter, M., Ianieri, A. (2008) Influence of temperature on biofilm formation by Listeria 
monocytogenes on various food-contact surfaces: relationship with motility and cell surface hydrophobicity. J Appl Microbiol. 104, 1552-1561.

Dourou, D., Beauchamp, C. S., Yoon, Y., Geornaras, I., Belk, K. E., Smith, G. C., Nychas, G. J. E., Sofos, J. N. (2011) Attachment and biofilm formation by Escherichia coli O157:H7 at different temperatures, on various food-contact surfaces encountered in beef processing. Int J Food Microbiol. 149 (3), 262-268.

Elias, S., Banin, E. (2012) Multi-species biofilms: living with friendly neighbors. FEMS Microbiol Rev. 36, 990-1004, DOI: 10.1111/j.1574-6976.2012.00325.x.

Espina, L., García-Gonzalo, D., Pagán, R. (2014) Impact of essential oils on the taste acceptance of tomato juice, vegetable soup, or poultry burgers. J Food Sci. 79, S1575S1583, doi:10.1111/1750-3841.12529.

Fisher, K., Phillips, C. A. (2006) The effect of lemon, orange and bergamot essential oils and their components on the survival of Campylobacter jejuni, Escherichia coli O157, Listeria monocytogenes, Bacillus cereus and Staphylococcus aureus in vitro and in food systems. J Appl Microbiol. 101, 1232-1240, doi:10.1111/j.1365-2672.2006.03035.x.

Flemming, H. C., Wingender, J. (2010) The biofilm matrix. Nat Rev Microbiol. 8, 623-633.

Fonseca, P., Moreno, R., Rojo, F. (2011) Growth of Pseudomonas putida at low temperature: global transcriptomic and proteomic analyses. Env Microbiol Rep. 3, 329339.

Garrett, T. R., Bhakoo, M., Zhang, Z. (2008) Bacterial adhesion and biofilms on surfaces. Prog Nat Sci. 18, 1049-1056.

Giaouris, E., Heir, E., Desvaux, M., Hébraud, M., Møretrø, T. és mtsi. (2015) Intra- and inter-species interactions within biofilms of important foodborne bacterial pathogens. Front Microbiol. 6, 841, DOI: 10.3389/fmicb.2015.00841.

Giaouris, E., Heir, E., Hébraud, M., Chorianopoulos, N., Langsrud, S. és mtsi. (2014) Attachment and biofilm formation by foodborne bacteria in meat processing environments: causes, implications, role of bacterial interactions and control by alternative novel methods. Meat Sci. 97, 298-309.

Goh, S. G., Leili, A.-H., Kuan, C. H., Loo, Y. Y., Lye, Y. L. és mtsi. (2014) Transmission of Listeria monocytogenes from raw chicken meat to cooked chicken meat through cutting boards. Food Control 37, 51-55.

Gomes, I. B., Malheiro, J., Mergulhão, F., Maillard, J. Y., Simões, M. (2016) Comparison of the efficacy of natural-based and synthetic biocides to disinfect silicone and stainless steel surfaces. Pathog Dis. 74 (4), ftw014, DOI: 10.1093/femspd/ftw014. 
Goulter, R. M., Gentle, I. R., Dykes, G. A. (2009) Issues in determining factors influencing bacterial attachment: a review using the attachment of Escherichia coli to abiotic surfaces as an example. Lett Appl Microbiol. 49, 1-7.

Guenther, E. (1948) The Essential Oils, Vol. 1, David van Nostrand Co. Inc. New York.

Guentzel, M. N. (1996) Chapter 26 Escherichia, Klebsiella, Enterobacter, Serratia, Citrobacter, and Proteus. In: Baron S. (ed.) Medical Microbiology, 4th edition. The University of Texas Medical Branch at Galveston, Galveston (TX) Available from: https://www.ncbi.nlm.nih.gov/books/NBK8035/ (2017.01.25.)

Gupta, P., Sarkar, S., Das, B., Bhattacharjee, S., Tribedi, P. (2016) Biofilm, pathogenesis and prevention-a journey to break the wall: a review. Arch Microbiol. 198, 1-15.

Gutierrez, J., Barry-Ryan, C., Bourke, P. (2008) The antimicrobial efficacy of plant essential oil combinations and interactions with food ingredients. Int J Food Microbiol. 124, 91-97.

Gutierrez, J., Bourke, P., Lonchamp, J., Barry-Ryan, C. (2009) Impact of plant essential oils on microbiological, organoleptic and quality markers of minimally processed vegetables. Innov Food Sci Emerg. 10 (2), 195-202.

Gyawali, R., Ibrahim, S. A. (2014) Natural products as antimicrobial agents. Food Control 46, 412-429.

Hedge, J. E., Hofreiter, B. T. (1962) Carbohydrate Chemistry 17. In: Whistler R. L., Be Miller, J. N. (eds.), Academic Press, New York, p. 420.

Hori, K., Matsumoto, S. (2010) Review: Bacterial adhesion: From mechanism to control. Biochem Eng J. 48, 424-434.

Hyldgaard, M., Mygind, T., Meyer, R. L. (2012) Essential oils in food preservation: mode of action, synergies, and interactions with food matrix components. Front Microbiol. 3, 12, doi: 10.3389/fmicb.2012.00012, PMCID: PMC3265747

Hyun, J. E., Bae, Y. M., Song, H., Yoon, J. H. Lee, S. Y. (2015) Antibacterial effect of various essential oils against pathogens and spoilage microorganisms in fresh produce. $J$ Food Safety 35, 206-219, doi: 10.1111/jfs.12162.

Jay, J. M., Loessner, M. J., Golden, D. A. (2005) Modern Food Microbiology. Springer Science+Busieness Media Inc., New York.

Jett, B. D., Hatter, K. L., Huycke M. M., Gilmore M. S. (1997) Simplified agar plate method for quantifying viable bacteria. BioTechniques 23, 648-650. 
Juven, B. J., Kanner, J., Schved, F., Weisslowicz, H. (1994) Factors that interact with the antibacterial action of thyme essential oil and its active constituents. J Appl Bacteriol. $76,626-631$.

Kakaraparthi, P. S., Srinivas, K. V. N. S., Kumar, J. K., Kumar, A. N., Rajput, D. K., Sarma, V. U. M. (2014) Variation in the essential oil content and composition of Citronella (Cymbopogon winterianus Jowitt.) in relation to time of harvest and weather conditions. Ind Crop Prod. 61, 240-248.

Kavanaugh, N. L., Ribbeck, K. (2012) Selected antimicrobial essential oils eradicate Pseudomonas spp. and Staphylococcus aureus biofilms. Appl Environ Microbiol. 78, 4057-4061.

Koo, O.-K., Martin, E. M., Story, R., Lindsay, D., Ricke, S. C., Crandall, P. G. (2013) Comparison of cleaning fabrics for bacterial removal from food-contact surfaces. Food Control 30, 292-297.

Krisch, J., Tserennadmid, R., Vágvölgyi, Cs. (2012) Interaction of essential oils and food components: consequences in food preservation. In: Valgimigli, L. (Ed.) Essential Oils as Natural Food Additives. Composition, applications, antioxidant and antimicrobial properties. Book series: Advances in Food Safety and Food Microbiology Nova Publishers Inc., NewYork, USA, pp. 361-376.

Kumar, C. G., Anand, S. K. (1998) Significance of microbial biofilms in food industry: a review. Int J Food Microbiol. 42, 9-27.

Kusumaningrum, H. D., Riboldi, G., Hazeleger, W. C., Beumer, R. R. (2003) Survival of foodborne pathogens on stainless steel surfaces and cross-contamination to foods. Int $J$ Food Microbiol. 85, 227-236.

Kuźma, Ł., Kalemba, D., Różalski, M., Różalska, B., Więckowska-Szakiel, M., Krajewska, U., Wysokińska, H. (2009) Chemical composition and biological activities of essential oil from Salvia sclarea plants regenerated in vitro. Molecules 14 (4), 1438-1447.

Laczay P. (2008) Élelmiszer-higiénia - Élelmiszerlánc-biztonság, Mezőgazda Kiadó.

Langsrud, S., Moen, B., Møretrø, T., Løype, M., Heir, E. (2016) Microbial dynamics in mixed culture biofilms of bacteria surviving sanitation of conveyor belts in salmonprocessing plants. J Appl Microbiol. 120, 366-378.

Lau, K. Y., Zainin, N. S., Abas, F., Rukayadi, Y. (2014) Antibacterial and sporicidal activity of Eugenia polyantha Wight against Bacillus cereus and Bacillus subtilis. Int J Curr Microbiol Appl Sci. 3 (12), 499-510. 
Layne, E. (1957) Spectrophotometric and Turbidimetric Methods for Measuring Proteins. Methods Enzymol. 10: 447-455.

Lebert, I., Leroy, S., Talon, R. (2007) Effect of industrial and natural biocides on spoilage, pathogenic and technological strains grown in biofilm. Food Microbiol. 24, 281-287.

Li, J., McLandsborough, L. A. (1999) The effects of the surface charge and hydrophobicity of Escherichia coli on its adhesion to beef muscle. Int J Food Microbiol. 53, 185-193.

Mith, H., Duré, R., Delcenserie, V., Zhiri, A., Daube, G., Clinquart, A. (2014) Antimicrobial activities of commercial essential oils and their components against foodborne pathogens and food spoilage bacteria. Food Sci Nutr. 2, 403-416.

Monroe, D. (2007) Looking for chinks in the armor of bacterial biofilms. PLOS Biology. 5 (11), e307.

Mourey, A., Canillac, N. (2002) Anti-Listeria monocytogenes activity of essential oils components of conifers. Food Control 13, 289-292.

Magyar Szabvány 6830-11:1999 A takarmányok táplálóértékének meghatározása

Nazzaro, F., Fratianni, F., de Martino, L., Coppola, R., De Feo, V. (2013) Effect of essential oils on pathogenic bacteria. Pharm. 6, 1451-1474.

Negi, P. S. (2012) Plant extracts for the control of bacterial growth: Efficacy, stability and safety issues for food application. Int J Food Microbiol. 156, 7-17.

Nostro, A., Cellini, L., Zimbalatti, V., Blanco, A. R., Marino, A., Pizzimenti, F., Di Giulio, M., Bisignano, G. (2012) Enhanced activity of carvacrol against biofilm of Staphylococcus aureus and Staphylococcus epidermidis in an acidic environment. Acta Path, Micro Im Sc. 120, 967-973.

Otter J. A., Vickery K., Walker J. T., deLancey Pulcini E., Stoodley P., Goldenberg S. D. és mtsi. (2015) Surface-attached cells, biofilms and biocide susceptibility: implications for hospital cleaning and disinfection. J Hosp Infect. 89, 16-27.

Oussalah, M., Caillet, S., Saucier, L., Lacroix, M. (2006) Antimicrobial effects of selected plant essential oils on the growth of a Pseudomonas putida strain isolated from meat. Meat Sci. 73, 236-244.

Oussalah, M., Caillet, S., Saucier, L., Lacroix, M. (2007) Inhibitory effects of selected plant essential oils on the growth of four pathogenic bacteria: E. coli O157:H7, Salmonella typhimurium, Staphylococcus aureus and Listeria monocytogenes. Food Control 18 (5), 414-420.

Palmer, J., Flint, S., Brooks, J. (2007) Bacterial cell attachment, the beginning of a biofilm. J Ind Microbiol Biot. 34, 577-588. 
Pandey A., Trivedi P., Kumar B., Chaurasia B. Palni L. M. S. (2006) Soil microbial diversity from Himalaya: Need for documentation and conservation, National Biodiversity Authority 1-66.

Pei R. S., Zhou F., Ji B. P., Xu J. (2009) Evaluation of combined antibacterial effects of eugenol, cinnamaldehyde, thymol and carvacrol against $E$. coli with an improved Method. J Food Sci. 74, 379-383.

Penna, T. C. V, Mazzola, P. G. M., Martins, A. M. S. (2001) The efficacy of chemical agents in cleaning and disinfection programs. BMC Infect Dis. 1, 16.

Pérez Ibarreche, M., Castellano, P., Vignolo, G. (2014) Evaluation of anti-Listeria meat borne Lactobacillus for biofilm formation on selected abiotic surfaces. Meat Sci. 96, 295-303.

Perricone, M., Arace, E., Corbo, M. R., Sinigaglia, M., Bevilacqua, A. (2015) Bioactivity of essential oils: a review on their interaction with food components. Front Microbiol. 6, 76, http://doi.org/10.3389/fmicb.2015.00076.

Petrova, O. E., Sauer, K. (2012) Sticky situations: Key components that control bacterial surface attachment. J Bacteriol. 194, 2413-2425.

Phillips, C. A. (2016) Bacterial biofilms in food processing environments: a review of recent developments in chemical and biological control. Int J Food Sci Tech. 51 (8), 1731-1743, DOI: 10.1111/ijfs.13159.

Poblete-Castro, I., Borrero-de Acuña, J. M., Nikel, P. I., Kohlstedt, M. Wittmann, C. (2017) Host Organism: Pseudomonas putida. In: Wittmann, C., Liao, J. C. (eds.) Industrial Biotechnology: Microorganisms, 1, Wiley-VCH Verlag GmbH \& Co. KGaA, Weinheim, Germany.

Prakash, B., Veeregowda, B. M. Krishnappa, G. (2003) Biofilms: A survival strategy of bacteria. Curr Sci. 85, 1299-1307.

Rendueles, O., Ghigo, J. M. (2012) Multi-species biofilms: how to avoid unfriendly neighbors. FEMS Microbiol Rev. 36, 972-989, DOI: 10.1111/j.15746976.2012.00328.x.

Rhoades, J., Gialagkolidou, K., Gogou, M., Mavridou, O., Blatsiotis, N., Ritzoulis, C., Likotrafiti, E. (2013) Oregano essential oil as an antimicrobial additive to detergent for hand washing and food contact surface cleaning. J Appl Microbiol. 115, 987-994.

Røder, H. L., Sørensen, S. J., Burmølle, M. (2016) Studying bacterial multispecies biofilms: Where to start? Trends Microbiol. 24 (6), 503-513. 
Rusenova, N., Parvanov, P. (2009) Antimicrobial activities of twelve essential oils against microorganisms of veterinary importance. Trakia J of Sci. 7, 37-43.

Sanchez-Vizuete, P., Orgaz, B., Aymerich, S., Le Coq, D., Briandet, R. (2015) Pathogens protection against the action of disinfectants in multispecies biofilms. Front Microbiol. 6, 705, DOI: 10.3389/fmicb.2015.00705.

Sarker, S. D., Nahar, L., Kumarasamy, Y. (2007) Microtitre plate-based antibacterial assay incorporating resazurin as an indicator of cell growth, and its application in the in vitro antibacterial screening of phytochemicals. Methods 42, 321-324.

Satpathy, S., Sen, S. K., Pattanaik, S., Raut, S. (2016) Review on bacterial biofilm: An universal cause of contamination. Biocatalysis Agricultural Biotechnol. 7, 56-66.

Shelef, L. A., Jyothi, E. K., Bulgarellii, M. A. (1984) Growth of enteropathogenic and spoilage bacteria in sage-containing broth and foods. J Food Sci. 49. 737-740.

Shi, X., Zhu, X., (2009) Biofilm formation and food safety in food industries. Trends Food Sci Technol. 20, 407-413.

Sieniawska, E., Los, R., Baj, T., Malm, A., Glowniak, K. (2013) Antimicrobial efficacy of Mutellina purpurea essential oil and $\alpha$-pinene against Staphylococcus epidermidis grown in planktonic and biofilm cultures. Ind Crop Prod. 51, 152-157.

Simões, M., Simões, L. C., Vieira, M. J. (2010) A review of current and emergent biofilm control strategies. LWT - Food Sci Tech. 43, 573-583.

Singh, A. Singh, R. K, Bhunia, A. K., Singh, N. (2003) Efficacy of plant essential oils as antimicrobial agents against Listeria monocytogenes in hotdogs. LWT - Food Sci Tech. $36,787-794$.

Solórzano-Santos, F., Miranda-Novales, M. G. (2012) Essential oils from aromatic herbs as antimicrobial agents. Curr Opin Biotech. 23, 136-141.

Soni, K. A., Oladunjoye, A., Nannapaneni, R., Schilling, M. W., Silva, J. L., Mikel, B., Bailey, R. H. (2013) Inhibition and inactivation of Salmonella Thyphimurium biofilms from polystyrene and stainless steel surfaces by essential oils and phenolic constituent carvacrol. J Food Protect. 76, 205-212.

Srey, S., Jahid, I. K., Ha, S.-D. (2013) Biofilm formation in food industries: A food safety concern. Food Control 31, 572-585.

Stewart, E. J., Ganesan, M., Younger, J. G., Solomon, M. J. (2015) Artifical biofilms establish the role of matrix interactions in staphylococcal biofilm assembly and disassembly. Sci Rep. 5, 13081, doi: 10.1038/srep13081. 
Stewart, P. S., Franklin, M. J. (2008) Physiological heterogeneity in biofilms. Nat Rev Microbiol. 6, 199-210.

Sutherland, J. P., Aherne, A., Beaumont, A. L. (1996) Preparation and validation of a growth model for Bacillus cereus: the effects of temperature, $\mathrm{pH}$, sodium chloride and carbon dioxide. Int J Food Microbiol. 30, 359-372.

Szczepanski, S., Lipski, A. (2014) Essential oils show specific inhibiting effects on bacterial biofilm formation. Food Control 36, 224-229.

Tajkarimi, M. M., Ibrahim, S. A., Cliver, D. O. (2010) Antimicrobial herb and spice compounds in food. Food control 21 (9), 1199-1218.

Tisserand, M. (2014) Aromatherapy vs MRSA: Antimicrobial essential oils to combat bacterial infection, including the superbug. Singing Dragon, UK, Chapter 8.

Tuson, H. H., Weibel, D. B. (2013) Bacteria-surface interactions. Soft Matter 9, 43684380 .

Usano-Alemany, J., Palá-Paúl, J., Herráiz-Peñalver, D. (2016) Essential oil yields and qualities of different clonal lines of Salvia lavandulifolia monitored in Spain over four years of cultivation. Ind Crop Prod. 80, 251-261.

Útmutató a Vendéglátás és Étkeztetés Jó Higiéniai Gyakorlatához I. kiadás (2012) Szerkesztette: Mezőgazdasági Szakigazgatási Hivatal Élelmiszer- és Takarmánybiztonsági Igazgatóság Vendéglátás és Étkeztetés Felügyeleti Osztálya, Budapest.

Valeriano, C., de Oliveira, T. L. C., de Carvalho, S. M., Cardoso, M. G., Alves, E., Piccoli, R. H. (2012) The sanitizing action of essential oil-based solutions against Salmonella enterica serotype Enteritidis S64 biofilm formation on AISI 304 stainless steel. Food Control 25, 673-677.

Van Houdt, R., Michiels, C. W. (2010) Biofilm formation and the food industry, a focus on the bacterial outer surface. J Appl Microbiol. 109, 1117-1131.

Warnke, P. H, Becker, S. T., Podschun, R., Sivananthan, S., Springer, I. N. és mtsi. (2009) The battle against multi-resistant strains: Renaissance of antimicrobial essential oils as a promising force to fight hospital-acquired infections. J Cranio Maxill Surg. 37, 392397.

World Health Organization (2006) Five keys to safer food manual. WHO Press, France.

World Health Organization (2015) Food Safety. (letöltve: 2017. január 3.) elérhető: http://www.who.int/mediacentre/factsheets/fs399/en/. 


\section{Köszönetnyilvánítás}

Köszönetemet fejezem ki Prof. Dr. Vágvölgyi Csabának, az SZTE TTIK Mikrobiológiai Tanszék vezetőjének, amiért lehetővé tette, hogy $\mathrm{PhD}$ munkámat a tanszéken készíthettem.

Hálával tartozom témavezetőmnek, Dr. Krisch Juditnak, amiért irányította és támogatta munkámat. Köszönöm belém fektetett bizalmát és kísérleteim sikeres elvégzéséhez és szakmai fejlődésemhez nyújtott segítségét.

Köszönet illeti Dr. Kerekes Erika Beátát, aki gyakorlati szaktudásával segítette munkámat. Köszönöm az évek során kapott rengeteg támogatást, tanácsot és biztatást a 312. labor dolgozóinak, elsősorban Dr. Baranyi Nikolettnek, Dr. Homa Mónikának, Dr. Tóth Liliánának és Dr. Virágh Máténak. Emellett köszönöm Kiss Noéminek, Dr. Kocsubé Sándornak, Dr. Kotogán Alexandrának, Nacsa-Farkas Elvirának, Szarkándi János Gergőnek és Dr. Takó Miklósnak is a segítségét, mindenkinek hálás vagyok a jókedvben eltöltött pillanatokért.

Köszönettel tartozom Prof. Dr. Alexander Prange-nek, amiért lehetővé tette számomra, hogy egy hónapot tölthettem a németországi Hochschule Niederrhein, Élelmiszerbevizsgáló laborjában vendégkutatóként.

Köszönettel tartozom továbbá Petkovits Tamásnak és Fazekas Attilának az elektronmikroszkópos felvételek során nyújtott segítségükért, Vörös Mónikának a DNS tisztítás során nyújtott segítőkészségéért, és Prof. Dr. Rajkó Róbertnek a Box-Behnken módszerrel történő fertőtlenítőszer optimalizálásnál nyújtott szakmai tanácsaiért.

A technikai segítségnyújtásért hálás vagyok Lele Máriának és Deákné Kulcsár Melindának, Lengyel Boglárkának a gazdasági ügyek intézéséért, a Mikrobiológiai Tanszék és a Mérnöki Kar dolgozóinak a segítőkészségükért és a kellemes légkörért.

A doktori képzésem támogatásáért, a biztatásaikért hálás köszönet jár a családomnak, amiért minden lehetőséget megkaptam, hogy tanulmányaimat gond nélkül és szeretetben el tudjam végezni. Barátaimnak is köszönöm a biztatást és az elismerést.

A dolgozat elkészítését az „Új utak a természetes anyag alapú gyógyszerkutatásban: Rendszermetabolomikai megközelítések növényi és mikrobiális eredetű bioaktív terpenoidok felkutatására” címü, GINOP-2.3.2-15-2016-00012 számú projekt támogatta. $\mathrm{Az}$ infrastruktúrális hátteret a GINOP-2.3.3-15-2016-00006 számú, „Mikrobiális génbankhoz kapcsolódó integrált élettudományi és hatóanyag kutatás-fejlesztési centrum” című pályázat (Széchenyi 2020 Program) biztosította. 